DEPARTMENT OF THE INTERIOR

UNITED STATES GEOLOGICAL SURVEY

GEORGE OTIS SMITH, DIRECTOR

WAThe-Supply Papher 337

\title{
THE EFFECTS OF ICE ON STREAM FLOW
}

BY

WILLIAM GLENN HOYT

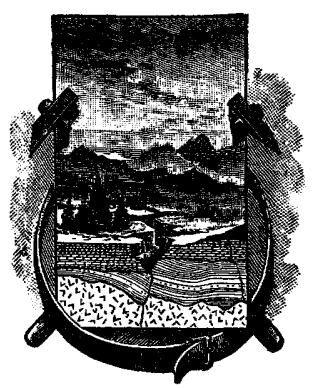

WASHINGTON

GOVERNMENT PRINTING OFFICE

1913 



\section{CONTENTS.}

Introduction

Factors that modify winter run-off

Classification

Climatic factors

Precipitation and temperature

Barometric pressure.- 17

Chinook winds. 18

Geologic factors_._. 19

Topographic factors

Natural storage

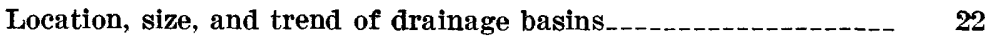

Character of streams

Vegetational factors..._.

Artificial control _-_.

Formation of ice-_- 24

General conditions _..._. 24

Surface ice _-_._-_- 24

Method of formation.................. 24

Length and severity of cold period_._- 25

Temperature of affluents_____._._.

Velocity of water and, character of bed

Fluctuations in stage___._. 27

Frazil_-_-_-_-_-_- 28

Anchor ice_._._.

Effect of ice on relation of stage to discharge 30

The control section

Surface ice -._-_-_. 31

General effects_._. 31

Effect on distribution of velocities in the vertical_........ 31

Gaging station studies._._. 32

Value of work

Elk River near Big Lake, Minn

Crow Wing River at Pillager, Minn_._._._._. 35

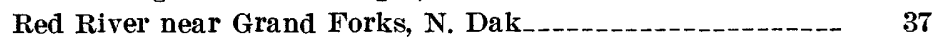

St. Mary River near Babb, Mont_____._. 38

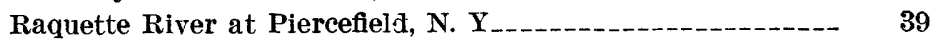

Frazil._-_. 40

Anchor ice._. 42

General effects_. 42

Gaging station studies_._- 42

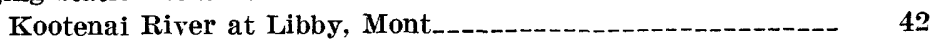

Schroon River at Riverbank, N. Y._._._._- 48 
Computation of flow of frozen streams

Methods available

First method

Second method.

Third method._. 51

Eye method _....... 51

Graphic method._.

Application of graphic method

Field methods _-_-_-_._- 57

Selection of stations___. 57

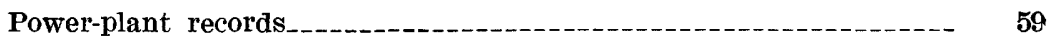

Gages_..._- 59

Climatologic records_______. 61

Discharge measurements_._._. 62.

Determination of section

Instruments _................ 63

Methods_._. 64

Number and cost

Personal equipment of the engineer. 68

Ice notes_._. 69

Office methods

General features._- 69

Computations_._- 70

Forms

Accuracy _.

Discharge measurements _._._. 72

Gage heights_._. 73

Estimates of daily and monthly discharge

Index 


\section{ILLUSTRATIONS.}

?LATE I. $A$ and $B$, Winter measurements on Rum River near Cambridge, Minn _._._.

II. Winter measurements: $A$, Vermilion River below Vermilion Lake, Minn.; B, Bigfork River near Big Falls, Minn.

III. Relation between open-water curve and ice measurements: Red River at Grand Forks, Minn

IV. Diagrams showing relation between temperature, gage heights, and discharge: Kootenai River at Libby, Mont_---

v. Diagrams showing relation between temperature, gage heights, and discharge: Schroon River at Riverbank, N. Y

VI. Diagrams showing relation between gage heights, backwater, and temperature: Rainy River at International Falls, Minn_

VII. $A$, Ice chisel, measuring stick, and bag; $B$, Winter measurement on Shoal Pond Brook, New Hampshire

2. Diagram comparing temperature and discharge: Mississippi River above Crow Wing River, Minn

3. Thermograph trace from Havre, Mont., January 22-26, 1907. showing increase in temperature caused by a chinook

4. Map showing location of Bigfork, Littlefork, and Vermilion rivers, Minn

5. Diagram showing relation between flow of Rainy River at International Falls and stage in Rainy Lake

6. Diagram showing average ice period from winter 1876-77 to winter 1895-96 inclusive

7. Diagram illustrating distribution of velocity under ice cover: Cannon River at Welch, Minn

8. Typical cross section of ice-covered stream and rating curve

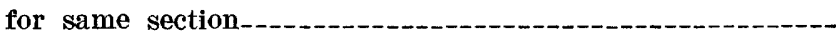

9. Relation between open-water curve and ice measurements: Elk River near Big Lake, Minn

10. Relation between open-water curve and ice measurements: Crow Wing River at Pillager, Minn.

11. Relation between open-water curve and ice measurements: St. Mary River near Babb, Mont

12. Relation between open-water curve and ice measurements: Raquette River at Piercefield, N. Y.

13. Cross section of Chemung River at Chemung, N. Y., showing effect of frazil

14. Gaging station on Kootenai River at Libby, Mont ments for Rainy River at International Falls, Minn

16. Diagrams showing relation between temperature, backwater, and discharge: Elk River near Big Lake, Minn.

17. Diagram showing factors used in making discharge measurements and new form proposed.

18. Proposed computation sheet._- 



\title{
THE EFFECTS OF ICE ON STREAM FLOW.
}

\author{
By William Glenn Hort.
}

\section{INTRODUCTION.}

The design, installation, and operation of any plant that depends for its success upon flowing water demands from those concerned a knowledge of the total flow of the stream and its wariation throughout the year, including not only the mean flow but also the maximum and minimum flow and the periods of their duration.

Stream-flow records extending over considerable periods are now available for many streams in the United States, and additional records are being obtained. For open-water periods methods for collecting stream-flow records have been standardized, the accuracy of such records has been established, and the laws of stream flow have been determined. On the other hand, during the winter the presence of ice affects the flow so much that the laws of flow pertaining to open channels are not entirely applicable, and no standard methods for collecting and interpreting data have been recognized. In many localities ice persists in the streams for periods ranging from a few days to several months, and, although the conditions resulting from ice are most pronounced in northern regions, they are prevalent over wide areas, and especially at high altitudes. As the minimum flowthe flow that determines the success or failure of most hydraulic works-is most likely to occur during periods when the streams are ice-covered and temperatures are low, accurate information concerning this flow is essential.

The flow of streams is ascertained primarily by means of the law of relation between stage and discharge. For most parts of the United States this relation remains so nearly constant during periods when the stream channels are unobstructed that it can be expressed in rating tables based on occasional discharge measurements, the mean daily flow being determined by applying to the table the records of mean daily stage. During the winter months low temperatures give rise to conditions that frequently disturb the openwater relation between stage and discharge and make the proper interpretation of winter records exceedingly difficult. 
A report on winter stream flow and its measurement, ${ }^{1}$ published by the Survey in 1907, brought together the information available at that time and formulated for the first time certain laws that relate to the distribution of velocity under ice and have been found to be applicable under practically all observed conditions. Knowledge of these laws has been of great value in making winter measurements of flow. The report dealt mainly with field operations in making discharge measurements, however, and contained little information in regard to the use of these measurements in estimating discharge from daily gage-height records and data concerning ice.

Recent studies have added much information in regard to the factors influencing stream flow when ice is present, and especially in regard to the collection and interpretation of winter records. With a view to standardizing, so far as practicable, the methods for ascertaining winter flow, this paper presents the available information on the subject, discussing the factors that influence the run-off during the periods of low temperature, the varieties of ice and their effect on the applicability of the laws of open-channel flow, and the collection and interpretation of necessary data. Some of the conclusions derived from the study of these factors differ from those previously reached because many of the earlier studies were local, both in scope and application, whereas effort is here made to deal broadly with conditions whose occurrence is coextensive with ice and low temperatures.

The report is based on the experience of the author in Minnesota during the winters of 1911-12 and 1912-13, supplemented by observations in Montana by B. E. Jones under the direction of W. A. Lamb, in New York and New England under the direction of C. C. Covert, and in Alberta, Canada, by Messrs. F. H. Peters and P. M. Sauder. Acknowledgment is also due to W. O. Hartwell, E. F. Chandler, S. B. Soulé, and B. J. Peterson for assistance in the work. Of the various publications which have been reviewed in connection with the preparation of the paper ${ }^{2}$ special mention should be made of the following:

Ice formation, with special reference to anchor ice and frazil, by Howard 'T. Barnes. John Wiley \& Sons, New York, 1906.

The flow of streams and factors that modify it, with special reference to Wisconsin conditions, by Daniel W. Mead: University of Wisconsin Bull. 425, 1911.

The determination of stream flow during the frozen season, by $\mathbf{H}$. K. Barrows and Robert E. Horton: U. S. Geol. Survey Water-Supply Paper 187, 1907.

\footnotetext{
1 Barrows, H. K., and Horton, R. E., Determination of stream flow during the frozen season: U. S. Geol. Survey Water-Supply Paper 187, 1907.

2 Since this paper was prepared the Commission of Conservation of Canada has published a report on Long Sault Rapids, St. Lawrence River, by A. V. White, with an appendix (No. 25) by Prof. H. T. Barnes, discussing the formation of surface ice, frazil, and anchor ice with special reference to conditions in the St. Lawrence.
} 


\section{FACTORS THAT MODIFY WINTER RUN-OFF.}

\section{CLASSIFICATION.}

The quantity and distribution of winter stream flow are the results of the combination of factors that may be classified as climatic, geologic, topographic, and vegetational. The climatic factors are precipitation, temperature, barometric pressure, and winds; the geologic factors include surface and underground rock structure and texture; the topographic factors include relief and slope, which determine the character and amount of natural storage, the location, size, and trend of the drainage basin, and the character of the streams and their tributaries; the vegetational factors comprise not only forestation but the effects of all plant growth and cultivation. A fifth factor is the result of the artificial control of the streams for water supply or power.

\section{CLIMATIC FACTORS.}

\section{PRECIPITATION AND TEMPERATURE.}

The climatic conditions that influence stream flow are probably more important than any others, but the conditions are so interrelated that it is difficult to distinguish the effect of one from that of another.

Stream flow during the winter is supplied by precipitation directly, in the form of rain or snow, and indirectly, from melting snow and from ground water.

Precipitation in the form of snow does not add perceptibly to the run-off of an area until the local temperature rises above the freezing point. Rain falling on frozen ground not covered with snow will run off quickly at a rate depending on the slope, for the frozen surface acts nearly as effectively as a rock stratum in preventing absorption by the ground. Rain falling on snow gradually increases the water equivalent of the snow to the point of saturation, when it will run off. Heavy snow on ground whose surface is not frozen may melt slowly from beneath, sink into the ground, and thus augment the supply of ground water. The amount of water held in snow cover naturally varies with variations in altitude and temperature. ${ }^{1}$

At the end of the growing season, generally about the 1st of October in the northern part of the United States, the ground water has generally been depleted by the needs of plant growth and by high evaporation, and conditions probably vary less from year to

1 The methods of measuring amount of water held in snow storage are described in Weather Bureau Bull. 445, Circular E, 1910; also in article by J. Cecil Alter entitled "Snow surveys for predicting stream flow": Eng. News, vol. 69, pp. 1110-1113, May 29, 1913. 
year than at any other season. ${ }^{1}$ From this time until a period whose beginning ranges from the middle of November to the 1st of December-the time depending on the year and locality-the groundwater table will tend to rise, since practically no water is needed for plant growth and loss from evaporation rapidly decreases as temperature decreases. After the ground becomes frozen to any considerable depth little water will be added to that stored in the ground until the spring breakup, as any surface water tends to run off (see fig. 1). The flow during the winter season therefore depends to a large extent on the amount of ground water present at the beginning of winter, and this amount in turn depends on the precipitation during the preceding period of replenishment.

The close relation between temperature and winter flow is revealed by a study of the precipitation. Temperature influences the winter

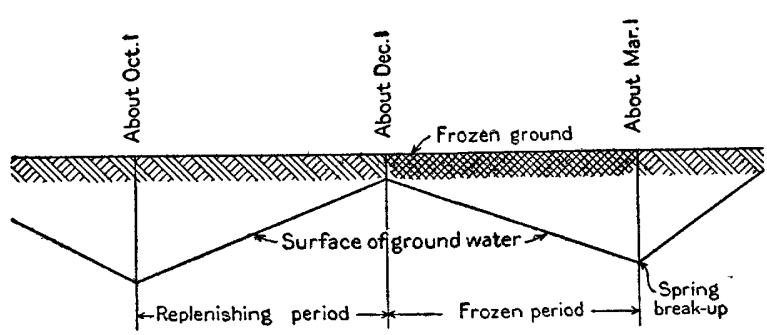

Figure 1.-Diagram showing position of ground-water table during period from fall to spring. run-off (1) by its effect on surface and ground water: and (2) by its effect on the character of the precipitation.

When the temperature falls below the freezing point a certain amount of surface water is changed to ice, and with continued low temperature this ice will gradually increase in thickness to a depth depending on the length and severity of the cold wave. The water so frozen will be held until it is released by temperatures under which the ice will melt. If such higher temperatures are delayed until spring, the water from the melting ice will join the run-off from melting snow and light rain to augment the spring floods. The amount of water held in storage as ice in stream channels and in shallow ponds may be considerable, particularly on streams so situated that the natural run-off per square mile is low. For example, the low-water flow of Rum River, in Minnesota (Pl. I), during January or February is about 70 second-feet. The river above the gaging station is approximately 100 miles long, its average width is about 100 feet, and its gradient is small. Ice forms over its entire surface in thicknesses ranging from $1 \frac{1}{2}$ to 2 feet. If in two months a 2-foot ice cover is formed, approximately $80,000,000$ cubic feet of water will be stored as ice, an amount equal to about 15 second-feet flow, or about 21 per cent of the low-water flow of the river at the gaging section for these two months.

${ }^{1}$ Hoyt, John C., Comparison between rainfall and run-off in the northeastern United States : Am. Soc. Civil Eng. Trans., vol. 59, p. 43, May, 1907. 


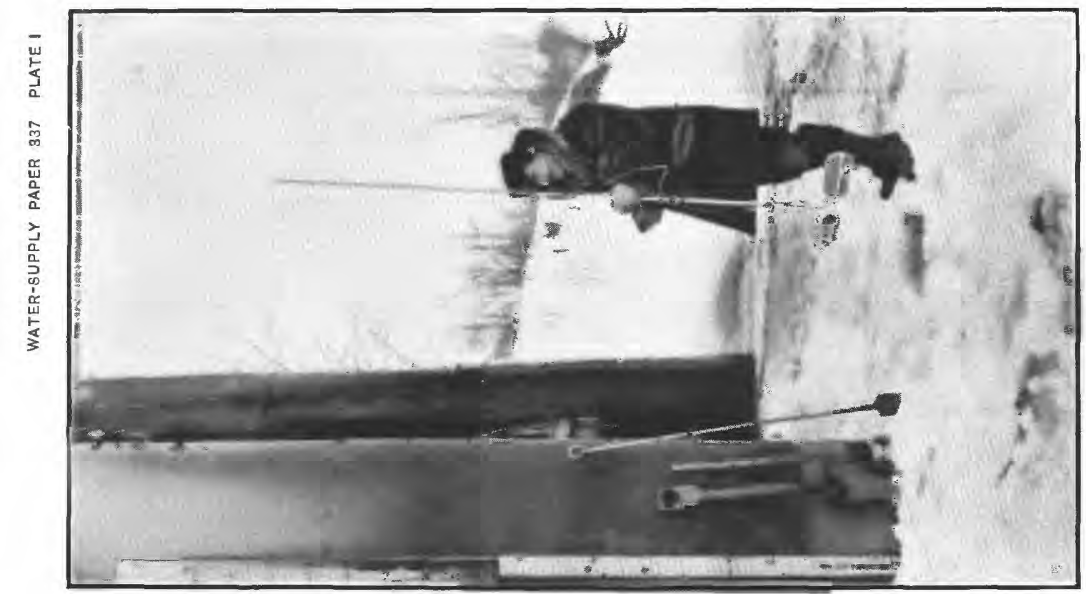

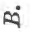

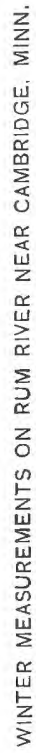
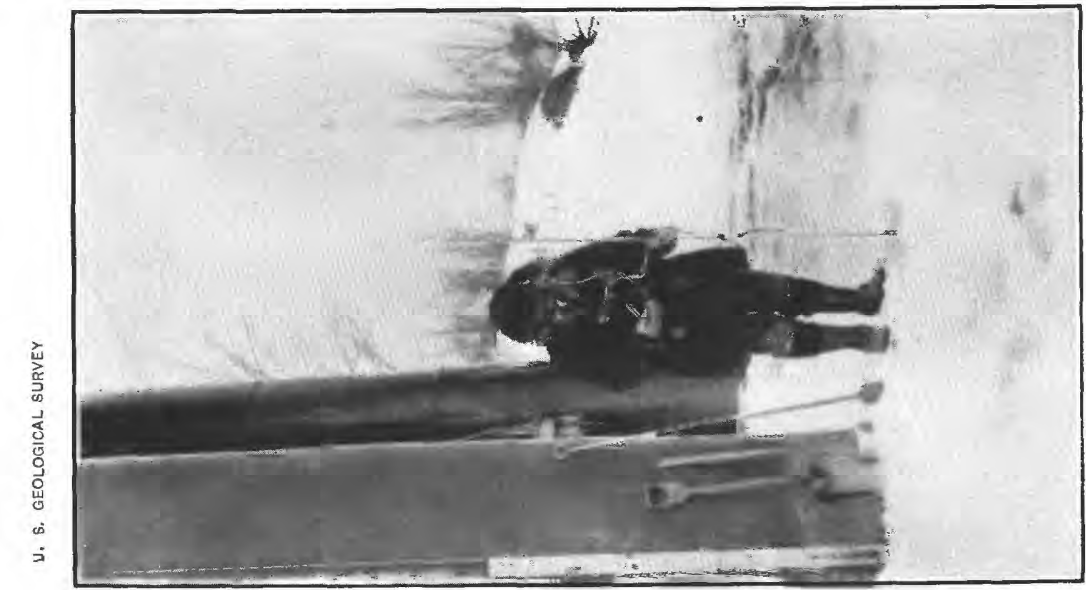

The freezing of the water also temporarily affects stream flow by suddenly increasing friction and thus causing the flow at a given cross section to decrease until the winter regimen has been established. At the beginning of each cold period, therefore, stream flow will drop suddenly, but will increase to some extent later.

Low temperature affects the run-off derived from ground water by affecting the rate of movement above the freezing point, the rate at which water at a temperature of $32^{\circ} \mathrm{F}$. flows through sand being about 64 per cent of its rate at a temperature of $60^{\circ} \mathrm{F} .^{1}$ The depth to which the ground will freeze ranges from 1 to 5 feet or more, depending on the character of soil, the vegetal covering, and the length and severity of the cold period. Early snows may form a cover that will protect the ground from freezing even under the influence of later low temperatures, and the condition of the groundwhether frozen or not-should be considered in all studies of the problem. The water contained within this zone is held in storage until it is released by higher temperatures.

Whether freezing of the ground water or obstruction of the channel by ice is more effective in causing decrease in discharge at the beginning of a cold period depends largely on the character of the drainage basin. In steep, mountainous areas, where a thin soil rests on solid rock, extreme cold will freeze the ground nearly to the rock and will cause a large decrease in ground flow; but streams draining such areas have, as a rule, narrow channels and considerable fall, so that obstructions due to ice hold back a comparatively small amount of water. In a rolling country, where the surface deposits consist of heavy sand or soil and where a large amount of water is in storage below the frost line, freezing affects only a small proportion of the stored water; but the streams in such regions usually are characterized by small slope and large cross section, so that obstructions due to ice will form a considerable check to the flow and may hold back large quantities of water in storage. In very flat valleys both these causes are operative, for the zone of freezing may extend below the bed of the streams, stopping all underground supply, and most of the surface flow may be held back by the large amount of ice that forms on the sluggish streams draining these valleys. Streams draining comparatively large basins consisting of flat valleys up to 2,000 square miles in extent may, under such conditions, cease to flow; whereas during the summer, even in periods of low precipitation, they would be fed by ground water.

As already stated, freezing temperatures indirectly affect ground water by converting the surface into an impervious stratum that prevents downward percolation of surface water.

1. Slichter, C. S., Field measurements of the rate of movement of underground water: v. S. Geol. Survey Water-Supply Paper 140, p. 13, 1905. 
Rising temperatures tend to increase run-off even if the rise does not extend above $32^{\circ} \mathrm{F}$, doubtless because it releases considerable ground water. Winter temperatures above $32^{\circ} \mathrm{F}$. add to run-off by melting ice and snow.

The diagrams comparing daily flow and temperature for Mississippi River above the mouth of Crow Wing River (fig. 2) and Kootenai River near Libby, Mont. (PI. IV, p. 46), graphically exhibit the relations.

The daily discharge of the Mississippi above the mouth of Crow Wing was determined by the Corps of Engineers, United States Army, from

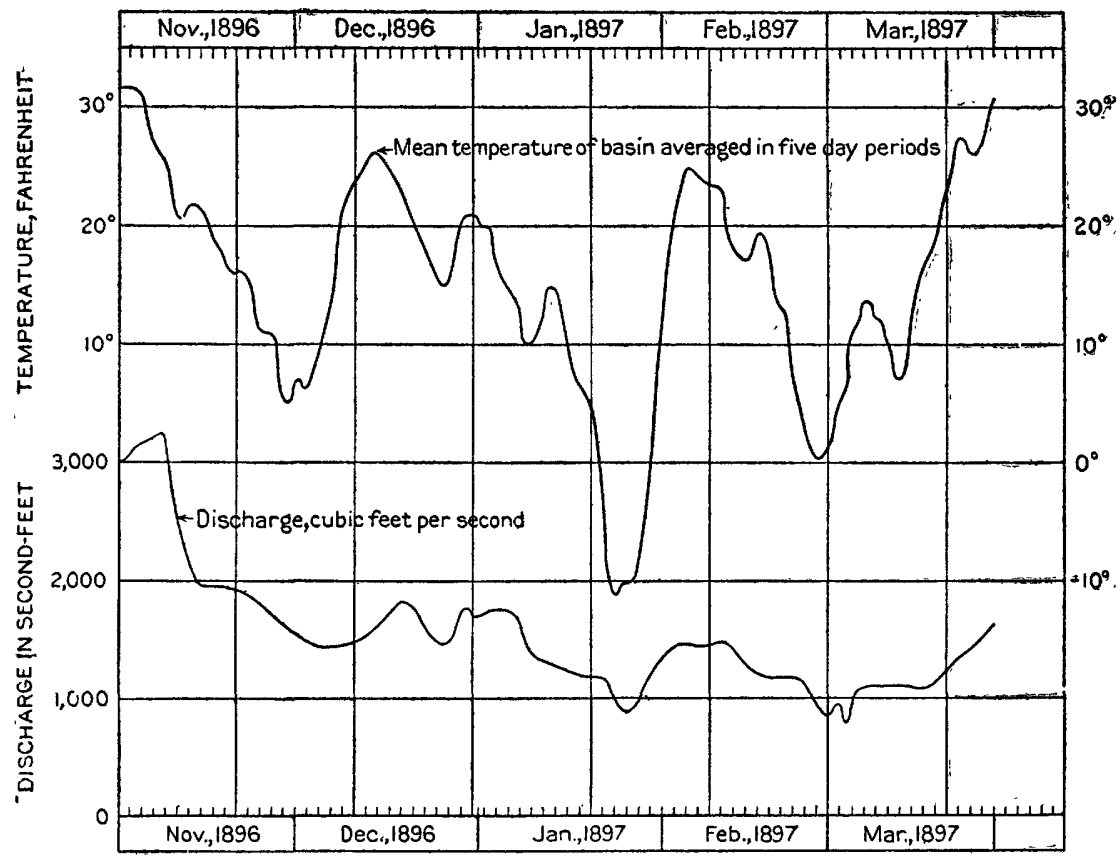

FIGURe 2.-Diagram comparing daily flow and temperature : Mississippi River above mouth of Crow Wing River, Minn.

discharge measurements made almost daily throughout the period. The temperature is the mean temperature for the basin, averaged in 5 -day periods. The slope of the main river and its tributaries is small and the many lakes and swamps above the stations tend to regulate the flow. These conditions are apparently less favorable to close correspondence between run-off and temperature than they would be on a stream having less lake and swamp storage. Nevertheless, the diagram shows a decrease in flow, amounting to 1,800 second-feet during the month of November, coincident with a drop in mean temperature from $31^{\circ} \mathrm{F}$. to $5^{\circ} \mathrm{F}$. Part of this flow was regained with the rise in temperature the early part of December, but 
with the drop in temperature in the middle of December the run-off again decreased; increase accompanied the small temperature rise at the end of the month. The slight increase in temperature in the middle of January did not increase the flow, but it retarded the decrease that began with the first drop in temperature on January 1, and reached a minimum a short time after the minimum temperature. It will be noticed that the stream flow increased immediately with the increase in temperature in the latter part of January, even though the temperature was still below freezing. The minimum flow for the winter was reached soon after the date of minimum temperature in February.

Kootenai River above Libby, Mont., drains a mountainous area on the western slope of the Rocky Mountains in British Columbia. As the basin contains many heavily forested areas ground storage during the open season is large, and on the higher areas, where precipitation is heavy, is at its maximum. It would seem therefore that the flow during the closed season would depend more largely on temperature than on fluctuations in the annual precipitation.

The diagram forming Plate IV (p. 46) shows the curves of maximum and minimum temperature, for the winter of 1912-13, the observed gage heights both before and after being corrected for anchor and surface ice, and the discharge determined from the corrected gage heights. It clearly exhibits general close relation between run-off and temperature. The drop in temperature that began January 4 and reached a minimum January 7 was accompanied by decrease in run-off from 3,000 second-feet on the 5th to 2,100 secondfeet on the 7 th. The succeeding rise in temperature caused the runoff to increase gradually to 3,000 second-feet on January 16. The fluctuation of run-off with changes in temperature during the month of February is also clearly shown. The minimum discharge, 2,080 second-feet, occurred February 10, about two days after the minimum temperature. After that date the flow gradually increased with rise in temperature until it reached 4,140 second-feet on February 19, about three days after the date of maximum temperature. The subsequent drop in temperature was accompanied by decrease in run-off. Increase in flow is noticeable February 10, although the temperature did not reach $32^{\circ} \mathrm{F}$. until the 12 th. This increase was undoubtedly caused by the releasing of stored ground water as a result of the higher temperature.

The effect of temperature and precipitation on stream discharge is also shown by the following table, which gives the results of a study of Minnesota streams. 


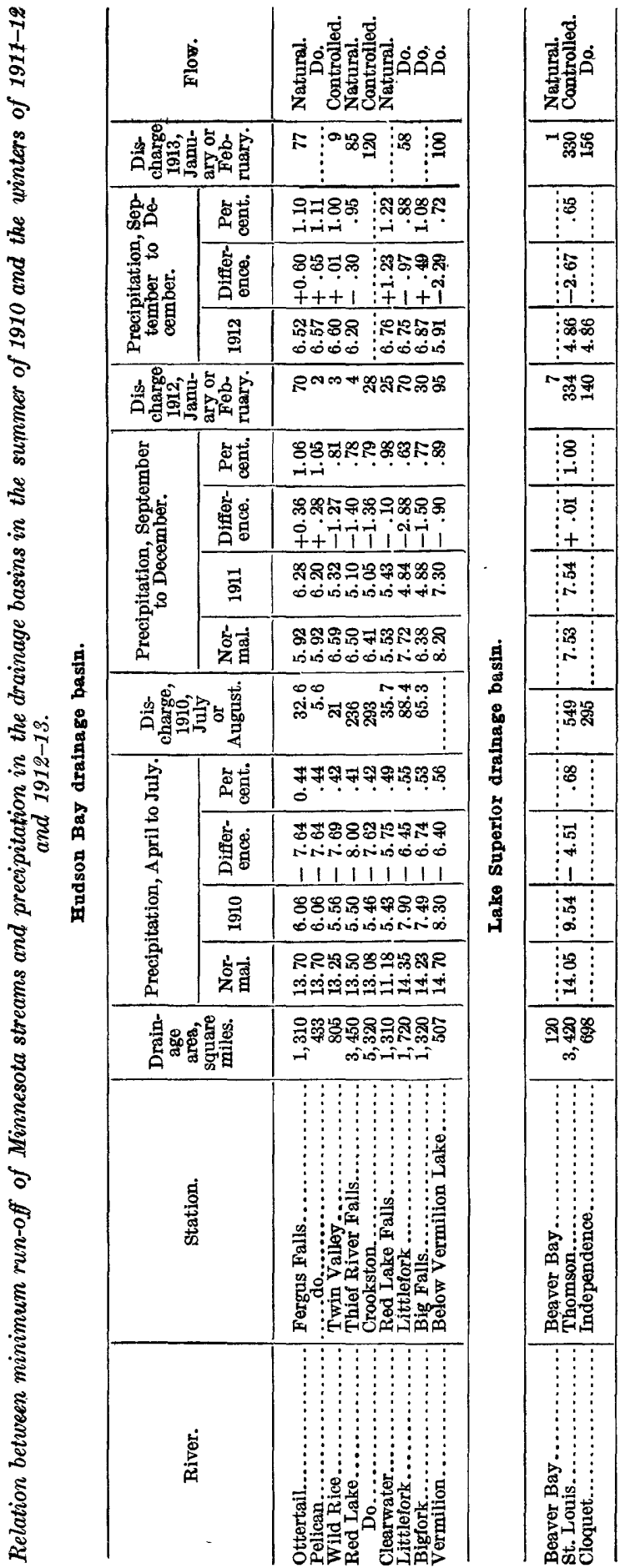




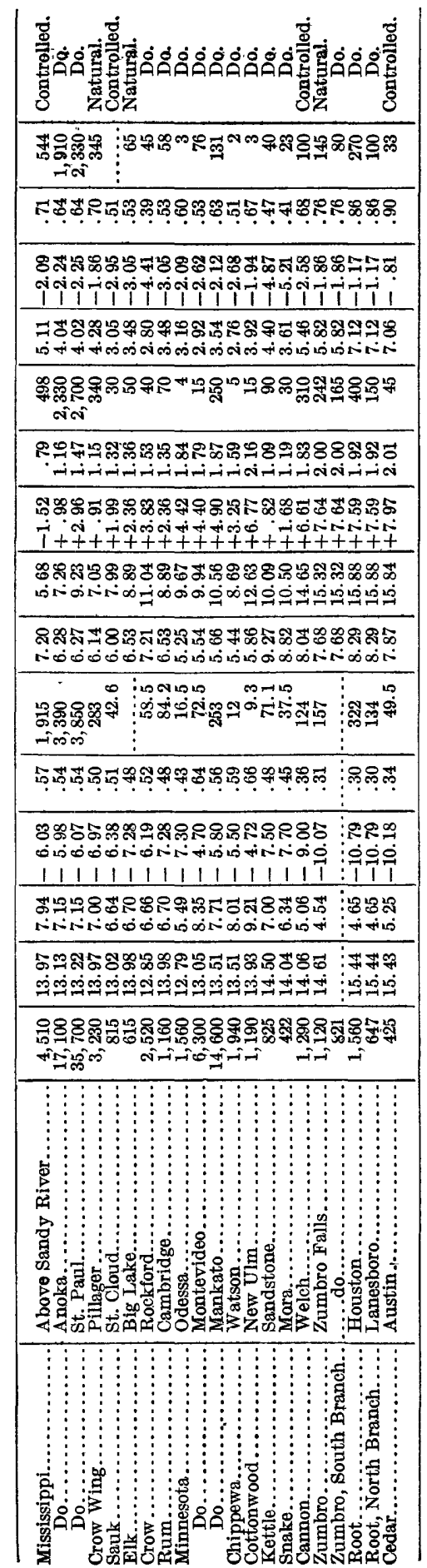


In the summer of 1910 most of the streams in Minnesota reached a stage that was probably nearly as low as the lowest open-water stage of 1864 , which has local reputation as the minimum stage. ${ }^{1}$ The cause of the low open-water flow of 1910 becomes evident when the normal precipitation for the four months preceding the period of low flow is compared with the actual precipitation during the same months in 1910. The table shows deficiency in precipitation ranging from 5.5 inches in the western and northwestern sections to more than 10 inches in the southern and southeastern parts of the State-that is, precipitation ranging from 30 per cent to 60 per cent of normal.

In January and February, 1912, ${ }^{2}$ notwithstanding the fact that, except over the Red River basin, the precipitation for the preceding months from September to December was equal to or exceeded the normal, the same streams reached a stage which in general was below that of the open-season flow in 1910. The table shows the normal precipitation from September to December inclusive ${ }^{3}$ - the four months that would ordinarily supply the flow from ground water during the winter-and the actual precipitation from September to December, 1911, the period of replenishment for the ground water supplying the low-water flow of January and February, 1912. In general, the figures indicate precipitation considerably above normal. The explanation of the conditions is found by considering temperature records. The 50 days from December 25, 1911, to February 12, 1912, were the coldest that have been recorded by the United States Weather Bureau for the State of Minnesota. At Crookston, in the northwestern part of the State, the temperature fell below zero for 49 days out of the 50, and on January 11,1912 , reached $-39^{\circ} \mathrm{F}$. The maximum temperature was below zero for 21 days and the highest recorded during the period was $24^{\circ}$, on January 31 and February 12. At St. Paul, the temperature for the same period fell below zero 34 days, the minimum being $-30^{\circ} \mathrm{F}$. on January 12. The conditions at Crookston and St. Paul were typical of those prevailing throughout the State. Probably nowhere in the State was the maximum temperature much if any above freezing during the entire period. The low flow of 1912 was therefore due not to lack of precipitation, but to the length and severity of the cold wave, which stopped all run-off except from ground water and undoubtedly retarded to a considerable extent the flow of the ground water.

1 Follansbee, Robert, Variability of run-of of Minnesota streams during the low-water flow of 1910 : Eng. News, vol. 65, pp. 536-538, May 4, 1911.

2 Hoyt, W. G., Gaging Minnesota streams in winter: Eng. News, vol. 68, pp. 499-502, Sept. 12, 1912.

? These limits do not apply exactly to all parts of the State, because of differences resulting from latitude. 
The table gives also the run-off record for the winter of 1912-13, in which the low flow was about the same as in 1912, though probably due to different conditions. The precipitation from September to December, 1912, preceding the period of low flow in January and February, 1913, was considerably below the normal for that period. During the winter of 1912-13 temperatures were normal or somewhat above and the flow from the ground water was probably little affected by low temperature.

The table therefore comprises records for a period (in 1910) of low open-season flow caused by a lack of precipitation, a period (in 1912) of low winter flow caused by low temperatures following a season in which precipitation was above normal, and a period (in 1913) of low winter flow caused by a lack of autumn precipitation, the winter temperature being normal. None of the low flows recorded in the table should be accepted as the absolute minimum that may be expected, because the available records do not cover a period of extremely low temperature preceded by a period of deficient precipitation. Although the low flow in 1910 might have been lower than any open-water flow recorded between 1864 and 1910, it was not of necessity lower than any closed-season flow within that period, since careful stream-gaging work during the winters of 1911-12 and 1912-13 gave results lower in general than were recorded during 1910. The years from 1864 to 1910 probably included more than one period of low precipitation during the fall followed by prolonged low temperature, causing a lower rate of flow than any that has been recorded, but unfortunately no extensive winter measurements were made until 1911-12. The conditions on the Minnesota streams, illustrated by the table, are typical of those on streams whose winter flow is affected by ice.

\section{BAROMETRIC PRESSURE.}

Changes in barometric pressure cause changes in the position of the ground-water table and therefore a change in the amount of ground water that reaches the rivers. Observations made by Baldwin Latham ${ }^{1}$ in 1881 in England, by Otto Lueger ${ }^{2}$ in Germany, and by F. H. King ${ }^{3}$ in America, show a variation in the flow of springs with changes in barometric pressure. In explanation of these changes Slichter ${ }^{4}$ says:

The phenomenon is usually explained by the expansibility of the air confined in the porous medium in the neighborhood of the ground water and of the air

\footnotetext{
1 Brit. Assoc. Adv. Sci. reports, p. 614, 1881, p. 495, 1883.

2 Einfluss des Atmosphärendrucks auf die Ergiebigkeit von Brunnen: Centralblatt d. Bauverw., p. 8, 1882.

${ }^{3}$ U. S. Dept. Agr. Weather Bull. No. 5, p. 50, 1892.

4 Slichter, C. S., The motions of underground waters: U. S. Geol. Survey Water-Supply Paper 67, p. 72, 1902.
}

$17020^{\circ}-$ wsP $337-13 \longrightarrow 2$ 
dissolved in the ground water itself. Even the air in the soil above the water table meets more or less resistance to its escape when the barometer falls and consequently a differential pressure must exist over the surface of the water table and the surface exposed at the well or spring.

A change of an inch in the height of the barometer corresponds to a change. in pressure of about 1 foot of water. It is evident that such a differential pressure exerted over the surface of the water table is sufficient to materially affect the flow into wells and springs.

The effect of barometric pressure on winter run-off has not been investigated, but during periods of low temperature there is in general a high barometric pressure which doubtless tends to decrease. run off.

\section{CHINOOK WINDS.}

In Alberta, Canada, and in portions of Montana and Wyoming, a wind called the "chinook" plays a very important part in the rate of winter run-off. Chinooks are more or less periodic and come from the west and southwest across the Rocky Mountains. As a rule, they

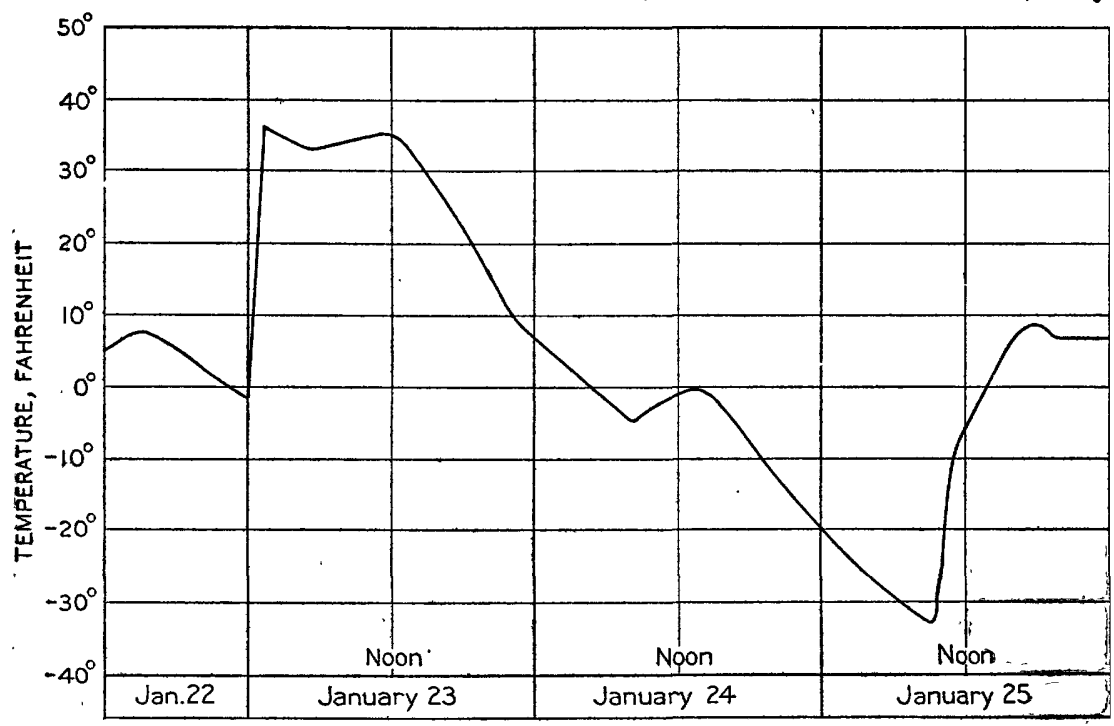

Figure 3.- Thermograph trace from Havre, Mont., January 22-26, 1907, showing increase in temperature caused by a "chinook."

follow an area of low pressure across the Canadian Rockies and cause heavy rain or snow on the west side and dry, hot winds on the east side. During a chinook the temperature will rise $30^{\circ}$ to $50^{\circ}$ (fig. 3) in a few hours ${ }^{1}$ and the snow will melt rapidly.

The resulting rapid increase in discharge, occurring when the streams are ice bound and not able to carry an added run-off, gives rise to serious complications in the methods of measuring. Besides the effect of such winds on the snow they may also tend to increase

\footnotetext{
${ }^{1}$ Moore, Willis E., Descriptive meteorology, pp. 186-187, D. Appleton \& Co., New York,
} 1910. 
the flow from springs as a result of the accompanying decrease in pressure.

The increase in temperature caused by chinook winds is shown by the following table, giving data for Bow River at Banff for January, 1912, contributed by Mr. G. H. Whyte, first assistant hydrographer in the office of the Commissioner of Irrigation, Calgary. In forwarding this record Mr. Whyte said that the most noticeable chinook of the period (Jan. 1-31) took place January 13, when the observer reported the weather cloudy, a drop in temperature of $26^{\circ}$ in three hours in the afternoon and a rise of many degrees by $8 \mathrm{p} . \mathrm{m}$. The chinook struck Calgary about 6 o'clock on the evening of the 14th.

Daily gage height and tempexature of Bow River at Banff, Alberta, for 1912.

[N. B. Sanson, observer: V. A. Newhall, hydrographer.]

\begin{tabular}{|c|c|c|c|c|c|c|c|c|}
\hline \multirow[b]{2}{*}{ Day. } & \multicolumn{2}{|c|}{ January. } & \multirow{2}{*}{$\begin{array}{c}\text { Gage } \\
\text { height } \\
\text { (ice). }\end{array}$} & \multirow{2}{*}{$\begin{array}{c}\text { Dis- } \\
\text { charge, } \\
\text { esti- } \\
\text { mates. }\end{array}$} & \multicolumn{2}{|c|}{ Temperature. } & \multicolumn{2}{|c|}{ Measured. } \\
\hline & $\begin{array}{c}\text { Gage } \\
\text { height } \\
\text { (water). }\end{array}$ & $\begin{array}{l}\text { Thick- } \\
\text { ness of } \\
\text { ice. }\end{array}$ & & & $\begin{array}{l}\text { Maxi- } \\
\text { mum. }\end{array}$ & $\begin{array}{l}\text { Mini- } \\
\text { mum. }\end{array}$ & $\begin{array}{c}\text { Gage } \\
\text { height. }\end{array}$ & $\begin{array}{c}\text { Dis- } \\
\text { charge. }\end{array}$ \\
\hline $\begin{array}{l}1 \\
2 \ldots \\
3 . \\
4 \\
5 \ldots \ldots \ldots\end{array}$ & \begin{tabular}{c|} 
Feet. \\
1.72 \\
1.76 \\
2.31 \\
2.15 \\
1.75
\end{tabular} & $\begin{array}{c}\text { Feet. } \\
1.1 \\
.9 \\
\cdots \\
1 \\
1\end{array}$ & $\begin{array}{c}\text { Feet. } \\
1.76 \\
1.75 \\
2.32 \\
2.30 \\
1.93\end{array}$ & $\begin{array}{r}\text { Sec. }-f t \text {. } \\
284 \\
285 \\
286 \\
282 \\
280\end{array}$ & $\begin{array}{r}{ }^{\circ} \mathrm{F} \\
7.7 \\
4.5 \\
10.4 \\
4.8 \\
5.0\end{array}$ & $\begin{array}{r}{ }^{\circ} \mathrm{F} . \\
-11.0 \\
-25.2 \\
-\quad 6.0 \\
-8.2 \\
3.2\end{array}$ & \begin{tabular}{c}
$\begin{array}{r}\text { Feet. } \\
1.78 \\
\ldots \ldots\end{array}$ \\
\hdashline$\ldots \ldots$ \\
\hdashline$\ldots \ldots$ \\
\hdashline$\ldots \ldots$
\end{tabular} & \begin{tabular}{c} 
Sec.-ft. \\
286 \\
$\cdots$ \\
\hdashline$\ldots$ \\
\hdashline$\ldots$
\end{tabular} \\
\hline $\begin{array}{r}6 \ldots \\
7 \ldots \\
8 \ldots \\
9 \ldots \\
10 \ldots\end{array}$ & $\begin{array}{l}1.95 \\
1.96 \\
1.96 \\
2.20 \\
2.42\end{array}$ & $\begin{array}{c}1 \\
\cdots .1 \\
1.5 \\
1.5 \\
\cdots\end{array}$ & \begin{tabular}{l}
1.9 \\
\hdashline 1.95 \\
2.1 \\
2.2
\end{tabular} & $\begin{array}{l}282 \\
283 \\
284 \\
286 \\
290\end{array}$ & $\begin{array}{r}-1.0 \\
15.3 \\
15.2 \\
-2.0 \\
-18.8\end{array}$ & $\begin{array}{l}-31.6 \\
-18.4 \\
-8.8 \\
-23.6 \\
-28.8\end{array}$ & $\because$ & \\
\hline $\begin{array}{l}11 \ldots \ldots \ldots \\
12 \ldots \ldots \ldots \\
13 \ldots \ldots \ldots \ldots\end{array}$ & $\begin{array}{l}2.20 \\
1.99 \\
2.00 \\
2.00 \\
2.03\end{array}$ & $\begin{array}{l}1.9 \\
1.2 \\
1.15 \\
\cdots \cdots \\
\cdots\end{array}$ & $\begin{array}{c}2.4 \\
2.3 \\
2.1 \\
\text { Open. }\end{array}$ & $\begin{array}{l}294 \\
292 \\
307 \\
313 \\
314\end{array}$ & $\begin{array}{l}12.2 \\
23.2 \\
35.8 \\
44.6 \\
45.0\end{array}$ & $\begin{array}{r}-37.6 \\
7.2 \\
5.8 \\
1.4 \\
34.6\end{array}$ & & \\
\hline $\begin{array}{l}16 \ldots \ldots \ldots \\
17 \ldots \ldots \ldots \ldots \ldots \\
18 \ldots \ldots \ldots \ldots \ldots \\
19 \ldots \ldots \ldots \ldots \ldots \\
20 \ldots \ldots \ldots \ldots\end{array}$ & $\begin{array}{l}1.75 \\
2.12 \\
2.35 \\
2.12 \\
2.12\end{array}$ & $\begin{array}{l}.8 \\
.8 \\
.8 \\
.9 \\
.95\end{array}$ & $\begin{array}{c}\text { Open. } \\
2.26 \\
2.3 \\
2.37 \\
2.19\end{array}$ & $\begin{array}{l}303 \\
312 \\
317 \\
309 \\
303\end{array}$ & $\begin{array}{l}37.0 \\
20.2 \\
14.1 \\
12.2 \\
22.6\end{array}$ & $\begin{array}{r}19.7 \\
-4.7 \\
-16.0 \\
-2.8 \\
1.1\end{array}$ & $\begin{array}{l}\cdots \cdots \\
\cdots \cdots \\
\cdots \cdots \\
\cdots \cdots\end{array}$ & $\begin{array}{l}\cdots \\
\cdots \\
\cdots \cdots \\
\cdots \cdots \\
\cdots\end{array}$ \\
\hline $\begin{array}{l}21 \ldots . \\
22 \ldots \\
23 \ldots \\
24 \ldots \\
25 \ldots\end{array}$ & $\begin{array}{l}2.00 \\
1.96 \\
1.94 \\
1.78 \\
1.71\end{array}$ & $\begin{array}{c}.95 \\
.95 \\
1\end{array}$ & $\begin{array}{l}2.2 \\
1.98 \\
1.78 \\
1.9\end{array}$ & $\begin{array}{l}298 \\
295 \\
291 \\
286 \\
280\end{array}$ & $\begin{array}{l}35.0 \\
33.0 \\
28.0 \\
31.0 \\
39.4\end{array}$ & $\begin{array}{l}18.5 \\
16.2 \\
11.3 \\
13.0 \\
28.1\end{array}$ & $\cdots$ & $\begin{array}{l}\cdots \cdots \\
\cdots \ldots \\
\cdots \cdots \\
\cdots \cdots \\
\cdots \cdots \\
\ldots\end{array}$ \\
\hline $\begin{array}{l}26 \ldots \ldots \\
27 \ldots \ldots \\
28 \ldots \ldots \\
29 \ldots \ldots \\
30 \ldots \ldots \\
31 \ldots \ldots\end{array}$ & $\begin{array}{l}2.02 \\
1.95 \\
1.75 \\
1.55 \\
1.40 \\
1.34\end{array}$ & $\begin{array}{l}1 \\
1 \\
\cdots .97 \\
.97\end{array}$ & \begin{tabular}{c} 
Open. \\
2.13 \\
\hdashline$\ldots . .$. \\
Open. \\
Open.
\end{tabular} & $\begin{array}{l}282 \\
280 \\
278 \\
273 \\
270 \\
270\end{array}$ & $\begin{array}{l}37.2 \\
32.1 \\
31.8 \\
42.0 \\
38.4 \\
32.0\end{array}$ & $\begin{array}{r}11.8 \\
15.2 \\
12.5 \\
26.3 \\
30.7 \\
9.2\end{array}$ & 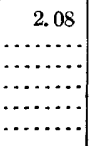 & 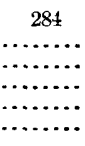 \\
\hline
\end{tabular}

\section{GEOLOGIC FACTORS.}

The amount of water held in storage in the ground at the beginning of the winter depends largely on the character of the material at and beneath the surface. In areas in which rocks lie at or near the surface nearly all the precipitation quickly reaches the streams and the ground will hold little water to aid in maintaining the flow when the surface water is diminished or exhausted. Unconsolidated 
materials collect and hold the water, the amount so held depending on the depth and nature of the surface material and the structure of the underlying rocks. Low temperature will congeal the water in the layers above the frost line so as to render them of little value as a source of supply during the winter. Other geologic conditions affect stream flow during the winter as in the summer.

\section{TOPOGRAPHIC FACTORS.}

NATURAL STORAGE.

The effect of topography on winter stream flow is of minor importance except as it influences the ground storage, a rolling or mountainous country affording a greater reservoir for ground water available for the streams than one which is so flat that the groundwater table lies in general below the level of the stream channels.

Other conditions being similar, the greater the extent of natural storage on a drainage basin the larger will be the winter flow.

The water stored in swamps and lakes may increase winter stream flow to a greater extent than it adds to the low flow of the open season, for evaporation from lakes and swamps during the autumn replenishing period is small and their water level rises, whereas during the summer loss from evaporation may exceed gain from precipitation, and their effect may be positively detrimental.

The effect of topography and natural storage on winter run-off is well illustrated by three streams in northern Minnesota-Bigfork, Littlefork, and Vermilion rivers-on which conditions have been studied. The position of these rivers is shown in figure 4.

Bigfork River rises in Itasca County and flows northward across Koochiching County to its junction with Rainy River.

The surface formation of the entire drainage basin is glacial drift so thick that rock outcrops are found only in a few places along the river. The basin is very flat and is so poorly drained that except in a comparatively narrow strip along the river it is swampy. Below the outlet of Lake Wabatwangang it contains practically no lakes; above that point about 15 per cent of the area is water surface. The mean slope of the basin is 0.00102 (slope $=\frac{\text { highest elev.-lowest elev. }}{\sqrt{\text { area }}}$ )

Littlefork River, which enters Rainy River a few miles east of the mouth of the Bigfork, meanders through a narrow, flat, wooded valley, in which there are few clearings. The surface formation is blue till and is underlain by crystalline rocks. There is less swamp land in this basin than in the basin of the Bigfork, and the mean slope is 0.00152 .

Vermilion River, which enters Rainy River through Little Vermilion Lake, is the outlet of Vermilion Lake, an extremely irregular 


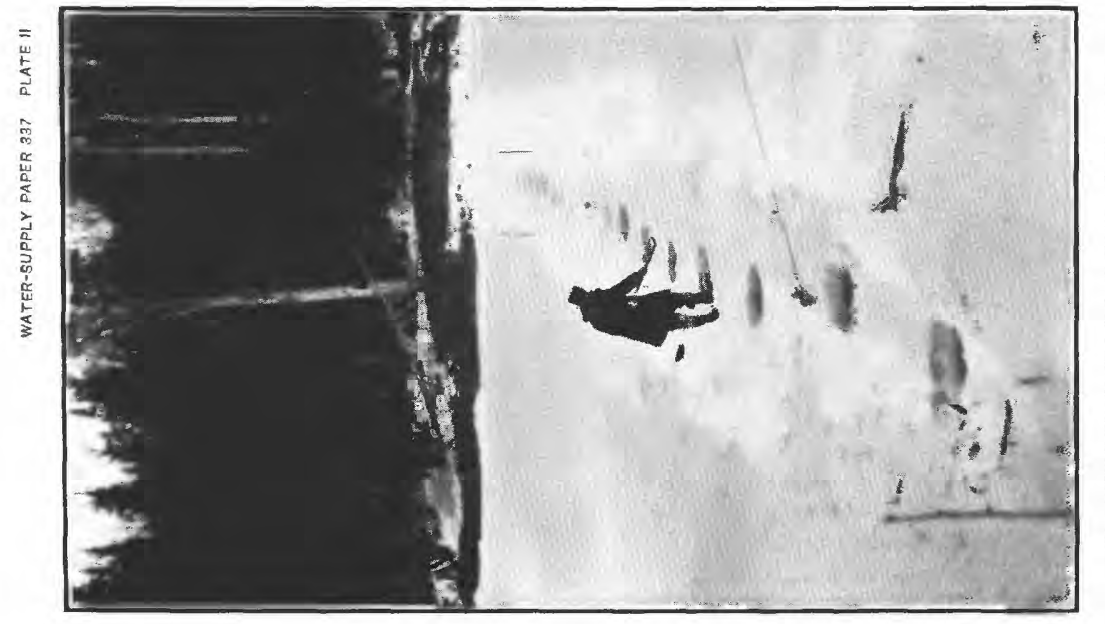

桌

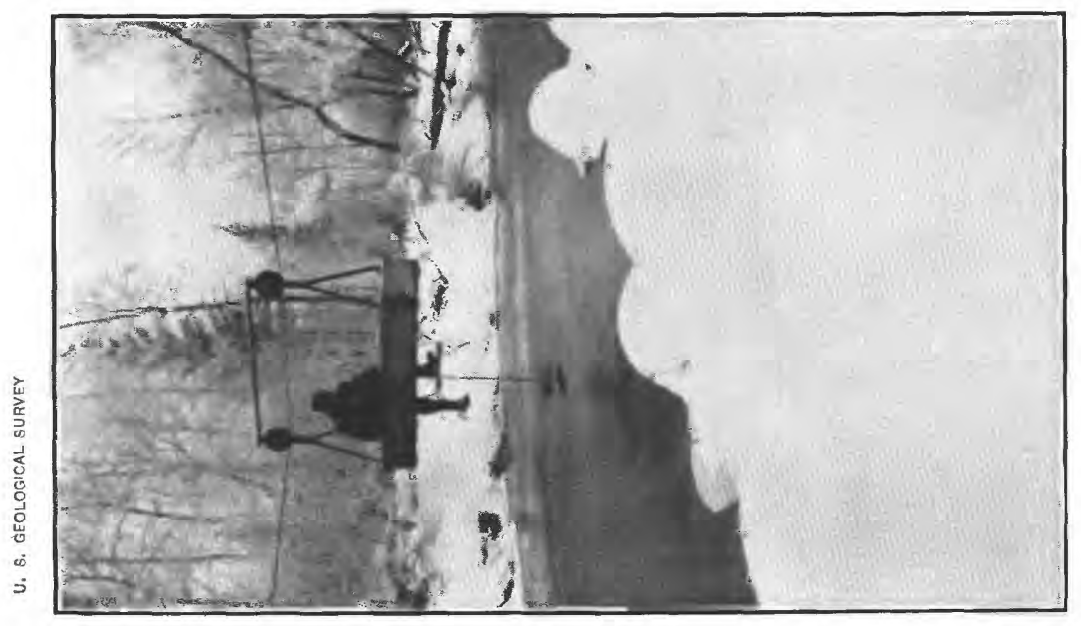

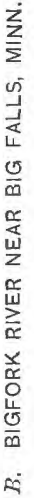

딴

난

z

यั

尔

zo

을

品

3

虫

㟧

品

중

$z$

永

荘 ชं 
. 
water body covering an area of 71 square miles. Tributary to Vermilion Lake and at a somewhat higher elevation is Trout Lake, which covers an area of 11 square miles. North of Vermilion Lake the basin embraces a region of light drift or bare rock and the topography is rugged; south of the lake is a much smoother region that is covered with glacial drift in which gravel predominates, and that gradually slopes to the Mesabi range. The mean slope of the basin is 0.0043 .

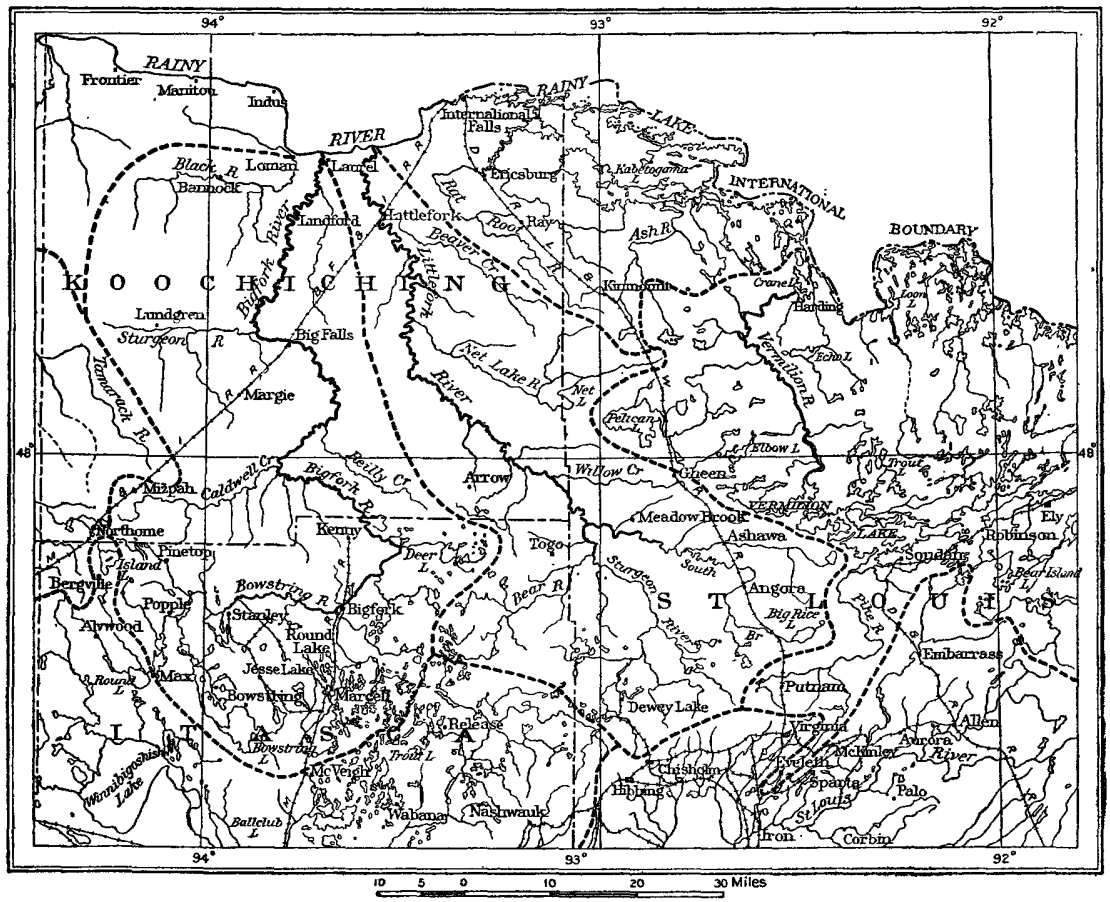

Figure 4.--Map showing location of Bigfork, Littlefork, and Vermilion rivers, Minn.

The rainfall and run-off from the three areas are compared in the following table:

Comparison of rainfall and rull-off in basins drained by Bigfork, Littlefork, and Termilion rivers, Minn.

\begin{tabular}{|c|c|c|c|}
\hline " & Bigfork. & Littlefork. & Vermilion. \\
\hline 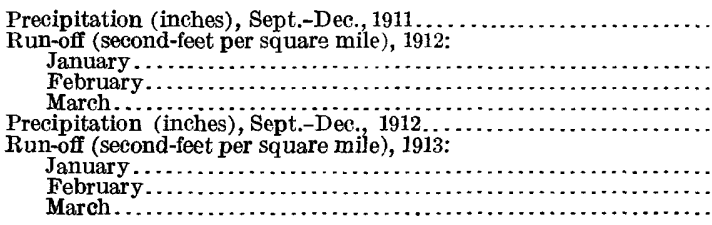 & $\begin{array}{c}4.84 \\
.023 \\
.023 \\
.026 \\
\ldots . \ldots\end{array}$ & $\begin{array}{l}4.88 \\
.049 \\
.044 \\
.041 \\
6.75 \\
.048 \\
.034 \\
.049\end{array}$ & $\begin{array}{l}7.30 \\
.250 \\
.231 \\
.188 \\
5.91 \\
.198 \\
.198 \\
.198\end{array}$ \\
\hline
\end{tabular}


The table shows clearly the effect of lakes and swamps in aiding winter flow. From the Vermilion basin, having large lake storage, the flow was nearly five times as great as from the swampy areas drained by the Bigfork and the Littlefork. The Littlefork, with a slightly greater slope and less swamp area, had a low-water flow nearly twice as large as that of the Bigfork. This relation held not only in the winter of 1911-12, following a season in which precipitation on the basin of the Vermilion had been greater than that on the basins of the Bigfork and Littlefork but also in the winter of 1913 , which followed a replenishing period of relatively low precipitation on the Vermilion basin.

LOCATION, SIZE, AND TREND OF BASINS.

The altitude and latitude of drainage basins also affect the winter flow of the streams. Streams in California, Washington, Oregon, and in general south of about $37^{\circ}$ latitude, except possibly those of northern New Mexico, Arizona, and the Rocky Mountain district, are not affected to any important extent by low temperatures except in the parts of the basins at high altitudes. Streams having their sources or parts of their basins in regions where low temperatures occur are so affected. Southward-flowing streams are less subject to floods caused by ice breakups than are streams flowing northward. On Red River of the North annual floods are caused by jamming of ice in the northern stretches as a result of the opening of the southern sections first. Chandler says: ${ }^{1}$

The water held as ice or snow is released by the spring thaws in the warmer southern portion of the valley several days or weeks before the spring warmth reaches the northern portion of the valley. Thus the snow water from the faraway southern boundaries and from the near-by districts reaches the lower river almost on the same day, and the flow surpasses the capacity of the channel. If the same amount of water were released over the whole valley in a single day (as is the case if there is a heary and widespread storm in sumner), the water from the nearest portions of the valley would reach the mouth of the river many days before that from the upper valley and the rise would be less in height because extended through a longer time. Second, the spring flood usually arrives at each section of the river channel before the ice has entirely thawed there. It is partially dammed by the heary ice still remaining from the February thickness of 2 or 3 feet and is forced to rise higher than would be the result if the same quantity of water should enter the river in late spring or summer when the channel is entirely clear.

- It can also be noted that the rise of each flood, at any season, is commonly more rapid than its fall in heiglit; this is a usual characteristic of other rivers.

CHARACTER OF STREAMS.

Streams whose gradients are steep flow so swiftly that surface ice will not form to any important extent, and a correspondingly small

1 Chandler, Elwyn F., The Red River of the North: Univ. North Dakota Quart. Jour., vol. 1, p. 236, April, 1911. 
amount of water will be held in ice storage. On the other hand, streams of small slope may be so icebound that a considerable part of their flow is held as ice during the winter, a condition typified by Rum River in Minnesota. (See p. 10.)

\section{VEGETATIONAL FACTORS.}

Heavy evergreen timber and underbrush, under which snow may collect, may have a detrimental effect on the winter flow because the snow will not receive the direct rays of the sun and will not thaw so rapidly as in the open. Such a vegetal cover, however, tends also to protect the ground from freezing, so that the augmented supply from ground water may offset the loss due to slow melting of the snow.

\section{ARTIFICIAL CONTROL.}

The artificial control of streams for power development, for navigation, for flood prevention, and for $\log$ driving presents a conflict of interests. Reservoirs used for power development only will, if possible, be so regulated that they will contain a large amount

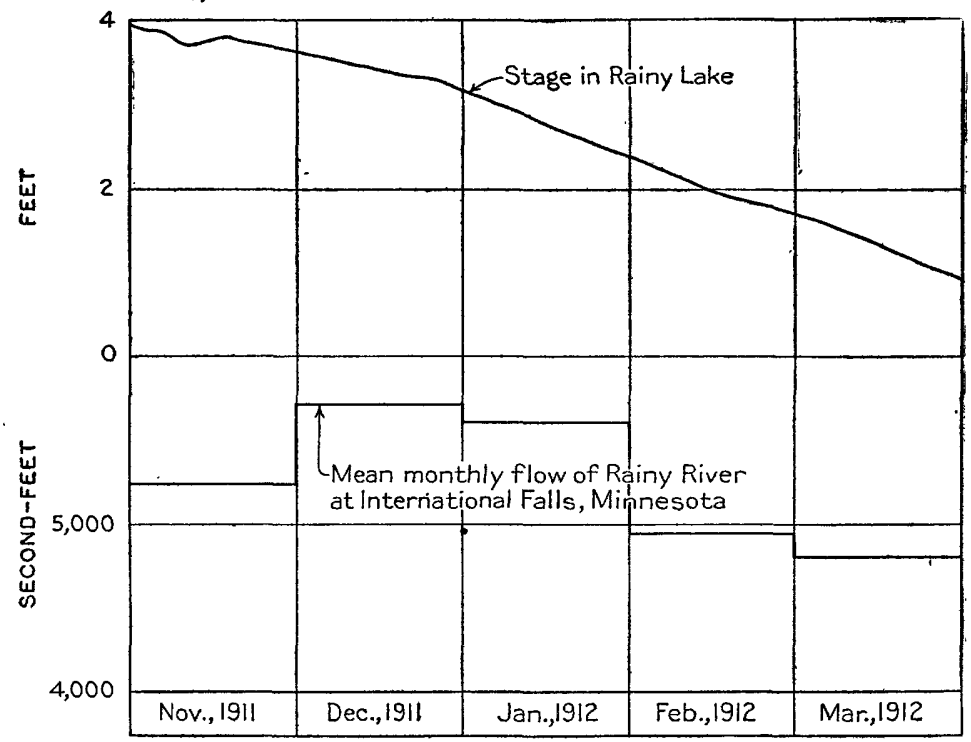

FigUR日 5.-Diagram showing relation between flow of Rainy River at International Falls and stage in Rainy Lake.

of water at the beginning of the winter and will be empty at the beginning of the spring break up. Reservoirs used in the interests of navigation will, as a rule, be closed during the winter, only the normal low-water flow being released. During open winters reservoirs so regulated may have a detrimental effect on the winter flow. The same may be said of reservoirs for flood prevention only. 
Reservoirs used to store water for logging operations can, as a rule, be used to benefit winter flow if the log-driving season ends in time to allow the reservoirs to be filled. In general, the gates of logging dams are kept open during the winter, so that, even though they are not used for storage, the natural flow will pass through. In general, therefore, the only reservoirs that will have a detrimental effect on winter flow are those at which not more than the normal low-water flow is released.

The effect of artificial control on winter run-off is illustrated by the diagram (fig. 5), showing the relation between stage in Rainy Lake and the flow of Rainy River at International Falls, Minn., from November 1, 1911, to March 31, 1912. The stage of water in Rainy Lake is controlled by a dam at International Falls. The area of Rainy Lake is approximately 310 square miles, which, with a range in stage of somewhat over 8 feet, provides for storing about 69 billion cubic feet. The storage is used entirely for power. It will be noticed that the elevation of the lake is kept as high as possible until the beginning of the winter, and is drawn on as soon as the natural flow of the river begins to decrease as a result of low. temperatures.

\section{FORMATION OF ICE.}

\section{GENERAL CONDITIONS.}

Water cooled to $32^{\circ} \mathrm{F}$. tends to crystallize, but the formation of ice on flowing streams is attended by complications that make it impossible to formulate rules to determine the amount. These complications so greatly affect the character and extent of the ice formed that a study of the various factors is essential to a study of records of winter run-off. The manner in which ice is formed and the character of the ice depend on the method of heat transmission and on local conditions which determine its existence as (1) surface ice, (2) frazil and slush ice, or (3) anchor ice.

\section{SURFACE ICE.}

Method of formation.-As a sheet of water is cooled by contact with the air the upper layer is first affected and becoming heavier than the water beneath it, sinks to the bottom, and is replaced by a warmer water from below. The cooler layers continue to sink until the water body is cooled to $39.1^{\circ} \mathrm{F}$, at which temperature the water attains its maximum density. As the temperature of the water drops below this point, the surface layer becomes cooler until it reaches $32^{\circ}$ F., when freezing starts and ice is formed. The ice begins to form on the shore or at the edge of bodies projecting above the water and gradually increases in extent and thickness. To the transmission of heat by convection is due the fact that ice generally spreads from the 
sides to the center, as the warmer air currents rise from the water and cooler air comes in from the sides so that the water is in contact with cooler air along the edge than at the center.

Ice does not form so quickly nor to so great thickness on running as on quiet water, partly because the agitation of the water tends to break off the small crystals as fast as they are formed and also because there will be more or less vertical motion of the water, causing: the warmer bottom layers to mix with the cooler layer lying directly under the ice, thereby raising its temperature somewhat. When surface ice has formed convection of air currents from water surface ceases and there is little radiation, especially if the ice is thick or is covered with snow. Heat is, however, conducted from the water beneath through the ice to the air above, thus causing the ice to thicken. As ice is a very poor conductor of heat the ice thickens from beneath very slowly, but thickness may be added by the gradual accumulation on the surface of frozen precipitation.

The following mathematical formula ${ }^{1}$ for computing the rate of ice formation on still water, based on the formation by heat conduction only, has been advanced by Prof. Howard T. Barnes, of McGill University :

$$
t=\frac{L S E}{K \theta}\left(1+\frac{E}{2}\right)
$$

where

$t$ is the time in seconds for the ice sheet to attain a thickness of $E$ centimeters;

$L$ is the heat of fusion, 80 calories;

$S$ is the density of ice, 0.9166 ;

$K$ is the conductivity of ice, 0.0057 calorie per degree difference of temperature per square centimeter per second;

$\theta$ is the difference in temperature, centigrade, between the underside of the ice sheet, $0^{\circ}$, and the air temperature. (Equivalent simply to the air temperature.)

The amount of ice that will form on a given section of a flowing stream will be determined by (1) the length and severity of the cold period; (2) the relative amount of the discharge received from lakes. ground .water, factory waste, etc.; (3) the velocity of water and character of bed; and (4) fluctuations in stage, both natural and artificial.

Length and severity of cold period.-The rate of growth of sheet ice formed on still water when the surface of the ice is free from snow is shown in the following table, which is based on the table prepared by Prof. Barnes. ${ }^{2}$ 
Rate of growth of sheet ice.

\begin{tabular}{|c|c|c|c|c|}
\hline \multirow{2}{*}{$\begin{array}{l}\text { Thickness } \\
\text { of ice sheet, } \\
\text { inches. }\end{array}$} & \multicolumn{4}{|c|}{ Temperature. } \\
\hline & $+14^{\circ} \mathrm{F}$ & $-4^{*} \mathrm{~F}$ & $-22^{\circ} \mathrm{F}$ & $-40^{c} \mathrm{~F}$. \\
\hline $\begin{array}{r}1 \ldots \ldots \ldots \\
6 \ldots \ldots \ldots \\
10 \ldots \ldots \\
12 \ldots \ldots \\
24 \ldots \ldots \\
36 \ldots \ldots \\
\ldots \ldots \\
\end{array}$ & 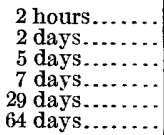 & $\begin{array}{r}1 \text { hour....... } \\
23 \text { hours....... } \\
3 \text { days...... } \\
4 \text { days....... } \\
14 \text { days...... } \\
32 \text { days....... }\end{array}$ & $\begin{array}{c}41 \text { minutes... } \\
16 \text { hours...... } \\
2 \text { days....... } \\
2 \frac{1}{2} \text { days....... } \\
9 \frac{1}{2} \text { days....... } \\
21 \text { days....... }\end{array}$ & $\begin{array}{l}31 \text { minutes. } \\
12 \text { hours. } \\
1 \text { day. } \\
2 \text { days. } \\
7 \text { days. } \\
16 \text { days. }\end{array}$ \\
\hline
\end{tabular}

For ice covered with snow the above table would have to be changed by unknown amounts.

A report of the United States Deep Waterways Commission * gives the information in the following table and in figure 6 concerning the duration of ice on ice-bound streams of the United States:

Duration of ice at points in the United states.

\begin{tabular}{|c|c|c|c|c|c|c|c|c|}
\hline \multirow{3}{*}{ Location. } & \multirow{3}{*}{\multicolumn{2}{|c|}{$\begin{array}{l}\text { Latitude } \\
\text { north. }\end{array}$}} & \multirow{3}{*}{\multicolumn{2}{|c|}{$\begin{array}{l}\text { Longi- } \\
\text { tude } \\
\text { west. }\end{array}$}} & \multirow{3}{*}{$\begin{array}{c}\text { Altitude } \\
\text { above } \\
\text { sea level. }\end{array}$} & \multicolumn{3}{|c|}{$\begin{array}{c}\text { Winter } 1876-77 \text { to winter } \\
1895-96 \text {, inclusive. }\end{array}$} \\
\hline & & & & & & \multicolumn{2}{|c|}{ Average dates. } & \multirow{2}{*}{$\begin{array}{l}\text { Number } \\
\text { of days } \\
\text { closed. }\end{array}$} \\
\hline & & & & & & Closing. & Opening. & \\
\hline & & 1 & & & Feft. & & & \\
\hline Albany, N. Y.. & & & & 45 & 1.30 & Dec. 22 & Mar. 26 & 94 \\
\hline Brainerd, Minn & $\$ 6$ & 29 & 94 & 10 & 1,150 & Nov. 20 & Apr. 17 & 149 \\
\hline Cairo, Ill. (Mississippi) . . . . . & 37 & 00 & 89 & 10 & 279 & Jan. 9 & Feb. 4 & 26 \\
\hline Cairo, Ill. (Ohio) ... & 37 & 00 & 89 & 10 & 279 & Jan. 21 & Jan. 29 & 8 \\
\hline 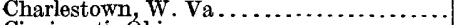 & 38 & 21 & 81 & 35 & 1,619 & Jan. 12 & Jan. 20 & 8 \\
\hline Cincinnati, Ohio $\ldots \ldots \ldots \ldots \ldots \ldots \ldots \ldots$ & 39 & 06 & 84 & 30 & 431 & Jan. 15 & Jan. 26 & 11 \\
\hline Davenport, Iowa ....... & 41 & 30 & 90 & 38 & 541 & Dec. 13 & Mar. 19 & 96 \\
\hline Des Moines Rapids, Iowa . .............. & 40 & 61 & 91 & 25 & 500 & Jan. 3 & Feb. 23 & 48 \\
\hline Dubuque, Iowa $\ldots . . . \ldots \ldots \ldots \ldots \ldots . . . . . . . .$. & 42 & 30 & 90 & 44 & 585 & Nov. 27 & Mar. 18 & 111 \\
\hline Fort Buford, N. Dak................. & 48 & 02 & 104 & 01 & 1,855 & Nov. 10 & Apr. 9 & 150 \\
\hline 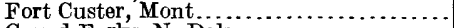 & 45 & 46 & 107 & 48 & 2,727 & Dec. 9 & Mar. 18 & 99 \\
\hline 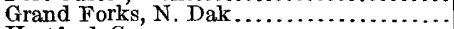 & 47 & 55 & 97 & 01 & 784 & Nov. 8 & Apr. 15 & 159 \\
\hline Hartford, Conn ....... & 41 & 45 & 72 & 39 & 0 & Dec. 17 & Mar. 7 & 80 \\
\hline Kansas City, Mc & 39 & 05 & 94 & 37 & 716 & Dec. 25 & Feb. 1 & 38 \\
\hline Keokuk, Iowa. & 40 & 22 & 91 & 26 & 477 & Jan. & Feb. 26 & 49 \\
\hline La Crosse, Wis. & 43 & 49 & 91 & 15 & 628 & Dec. & Mar. 24 & 107 \\
\hline Mankato, Minn . & 44 & 08 & 94 & 00 & 756 & Nov. 29 & Apr. 5 & 127 \\
\hline Montreal, Quebec. & 45 & 31 & 73 & 33 & 23 & Dec. 10 & Apr. 19 & 130 \\
\hline Moorhead, Minn... & 46 & 52 & 96 & 44 & 866 & Nov. 17 & Apr. 17 & 150 \\
\hline Morris, Ill ........... & 41 & 21 & 88 & 25 & 480 & Jan. 9 & Feb. 28 & 50 \\
\hline Nebraska City, Nebr.. & 40 & 40 & 95 & 51 & 907 & Dec. 21 & Mar. 1 & 70 \\
\hline Peoria, Ill ...... & 40 & 41 & 89 & 37 & 432 & Dec. 21 & Feb. 28 & 60 \\
\hline Pierre, S. Dak. . & 44 & 24 & 100 & 17 & 1,426 & Nov. 22 & Apr. 2 & 131 \\
\hline Pittsburgh, $\mathrm{Pa}_{\mathbf{Y}}$ & 40 & 32 & 80 & 02 & 699 & Jan. 27 & Jan. 29 & \\
\hline Rochester, N. Y . & 43 & 08 & 77 & 42 & 508 & Dec. 13 & Apr. 6 & 114 \\
\hline St. Paul, Minn... & 44 & 58 & 93 & 03 & 683 & Nov. 24 & Apr. 12 & 139 \\
\hline Sioux City, Iowa. & 42 & 29 & 96 & 24 & 1,066 & Dec. 17 & Mar. 17 & 90 \\
\hline St. Charles, Mo.. & 38 & 46 & 94 & 05 & 416 & Jan. 12 & Jan. 31 & 19 \\
\hline Whitehall, N. Y ...... & 43 & 34 & 73 & 24 & 95 & Dec. 25 & Apr. 6 & 102 \\
\hline Zanesville, Ohio......... & 39 & 59 & 82 & 00 & 678 & Jan. & Feb. 25 & 53 \\
\hline
\end{tabular}

The report shows a maximum average duration of 158 days of ice on Red River of the North at Grand Forks, N. Dak., and a minimum a verage duration of 11 days on Ohio River at Cincinnati, Ohio. On still water, such as the Duluth-Superior Harbor, Lake Superior, ice begins to form about November 15, attains a maximum thickness in 
the later part of February, and disappears about April 10, making the average length of ice cover about 1.50 days. In unprotected parts of the harbor the average thickness is about 27 inches; in shallow bays a maximum thickness of 52 inches has been reported by the United States Weather Bureau. Assuming that the ice at Duluth reaches a maximum thickness the latter part of February, using the average temperature for the period from November 15 to February 20, and applying Prof. Barnes's formula (p. 25), a probable thickness of 45 inches is obtained. Conditions other than those of heat conduction therefore appear to reduce the thickness of ice formed by nearly one-half.

Temperature of affuents.-The amount of ice formed is, of course, affected by any condition that tends to raise the temperature of water. Water flowing from a lake or millpond whose surface is ice covered may be at a temperature sufficiently high to prevent the formation of ice on the stream for a considerable distance below the outlet point.

At a depth of 30 or 40 feet below the surface the temperature of the ground remains practically constant throughout the year at very

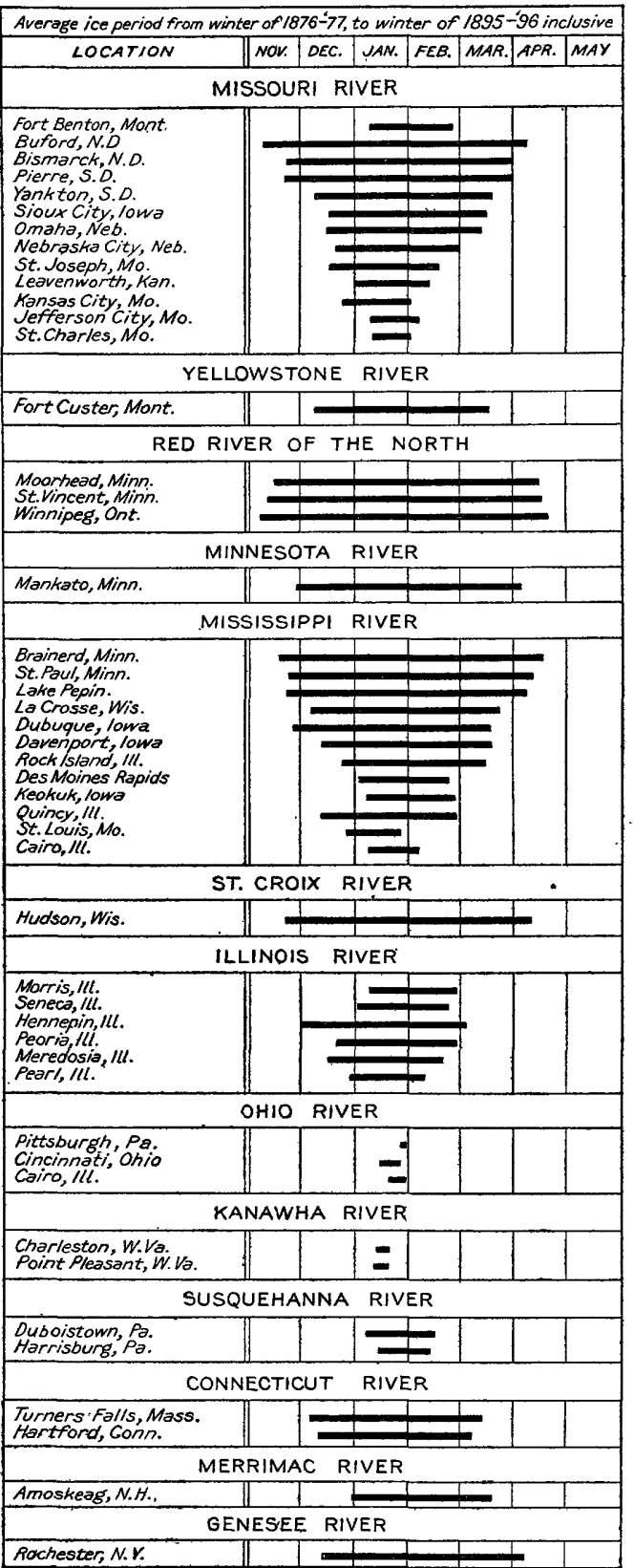

FIgURe 6.-Diagram showing average ice period from winter of $1876-77$ to winter of $1895-96$, inclusive. From report of the United States Deen Waterways Commission: Fifty-fourth Cong., 2d sess., H. Doc. No. 192 
nearly the mean annual temperature of the air above-in the northern section of the country $35^{\circ}$ to $40^{\circ}$. Flow derived from deep-seated ground water and springs may therefore so increase the temperature of the stream water near the point of inflow-the amount depending on the quantity of inflow-that ice will not form. On rivers and lakes the influence of the ground water becomes apparent, either by the absence of ice or by the presence of "blowholes." The warm water from factory waste and from sewers has the same effect. The thinness or absence of ice along the banks of rivers and shores of lakes is often probably due to relatively warm ground water inflowing at these points.

The variation in the flow of springs and ground water from year to year is shown by the fact that under practically the same conditions of temperature a stream will be frozen over in places in one year but will remain open the following year.

Velocity of water and character of the bed.--The formation of a cover of ice may be prevented by high velocity of water or by roughness of the stream bed, which causes agitation of the water. In general, these conditions favor the formation of frazil or of anchor ice.

Fluctuations in stage.-When temperatures are about $32^{\circ} \mathrm{F}$, the daily fluctuations in stage caused by the operation of a power plant will tend merely to retard the formation of a surface cover of ice on the stream below the dam; when temperatures are lower, however, a heavy ice cover may form which will not rise and fall with the water to any extent, but over which water will flow and freeze, thus giving an ice cover considerably thicker than that which would form at the same temperature with no fluctuation in discharge. On some streams ice has formed to a thickness of 3 or 4 feet as a result of fluctuations caused by the operation of power plants.

Fluctuations in stage caused by increase in flow may lift the ice and make it irregular in thickness. In places, also, the freezing of water flowing on the surface of the ice will leave alternate layers of flowing water between two ice surfaces.

In general, irregularity in the flow of a stream tends not only to decrease the thickness of the ice but also to make it irregular both in manner of formation and in physical appearance.

\section{FRAZIL.}

If the velocity of a stream is sufficient to prevent the formation of surface ice and the temperature of the water is $32^{\circ} \mathrm{F}$., "frazil" (a French Canadian term for fine spicular ice) will be formed. In the formation of this ice enough latent heat is released to keep the temperature of the water at $32^{\circ} \mathrm{F}$. Experiments ${ }^{1}$ made by Prof.

1 Barnes, Howard T., Formation of anchor ice anā precise temperature measurements : Am. Soc. Mec. Eng., Trans. vol. 26, p. 569, 1905. 
Howard T. Barnes by means of an electrical resistance thermometer so constructed that it would measure a change in temperature of $0.001^{\circ}$, indicated that flowing water in a stream could not be cooled more than one-hundredth of a degree below $32^{\circ} \mathrm{F}$. without the formation of ice crystals. Frazil consists of fine, elongated needles, cubical crystals, and plates, and is probably formed in maximum quantities during clear windy nights when the temperature is low. It never forms under a cover of ice, but it is carried with the current both yertically and horizontally, and, as shown by observations made on the St. Lawrence and on other rivers, may be transported for long distances both in open water and under ice cover, where it may jam and become compact enough to support bodies of considerable weight.

During periods of intense cold enormous quantities of frazil will form on uncovered, agitated bodies of water, which, when large quantities are present has a very dirty appearance. Small quantities in the water can be detected only by close observation.

The amount of frazil formed probably depends more largely than surface ice on climatic conditions other than temperature. At any given temperature below $32^{\circ} \mathrm{F}$. less frazil will form on a clear sunny day than on a cloudy windy one when the water will be agitated and there will be a considerable amount of radiation from the surface cooling it. On sunny days the heat absorbed by the water will to some extent conteract the effect of low temperature.

\section{ANCHOR ICE.}

Anchor ice is similar in many respects to frazil, but is formed in $\mathrm{n} n$ entirely different manner. By people of the south of Scotland it is called "loppered" ice because of its resemblance to sour milk, and by the French "moutonnée" from its fancied resemblance to the backs of white sheep at rest. Since 1788 various theories have been advanced to account for its formation. The theory now generally accepted is that it is due to the transmission of heat by radiation.

Anchor ice forms in large quantities on the beds of rivers or on obstacles under the water surface, but is never found in place under ice cover or under bridges. It forms chiefly during the night, when radiation from the ground is at a maximum, and apparently rarely forms in the daytime when radiation is at a minimum. It forms most rapidly on dark colored rocks, from which radiation is greater than on rocks that are light colored, and to a greater extent in shallow water than in deep, being rarely found at depths greater than 30 feet. When the rays of the sun reach anchor ice it becomes detached from the bed of the river and rising, often brings with it to the surface small rocks and other objects. It may grow to a thickness of a foot in a single night, and it may become thicker than this by the addition of frazil that has lodged on and frozen to it. 
The influence of the sun is especially noteworthy in connnection with the formation of frazil and anchor ice, for by warming the water it tends to prevent the formation of frazil and to detach anchor ice and bring it to the surface where it will float away.

\section{EFFECT OF ICE ON RELATION OF STAGE TO DISCHARGE.}

\section{THE CONTROL SECTION.}

The elevation of the water surface of a stream flowing in an open channel is determined from point to point by a succession of controls that may conveniently be referred to as control sections. These control sections of the stream may be dams or weirs, crests of rapids or abrupt falls, bars extending across the river, or, where the slope is uniform throughout, long stretches of the river bed. The water surface above each control section is determined by the height of water at the control section. Computations of daily discharge during periods of open water are based on the hypothesis that so long as the character of the river at the control section remains unchanged the discharge will remain constant for the same stage and will vary with the stage according to some fixed law. ${ }^{1}$ The open-water rating curve is the graphic representation of the formula for the discharge over the control section of the gage. Any change in the control section will change the position or shape of the curve. In considering winter discharge it is assumed that the control section remains constant except for ice, and that the causes for changes in the discharge curve for any gaging station are due to ice alone. For most sections this is probably true, as, except for ice, on northern streams changes in the control sections are due mainly to the scouring action at high water or the growth of vegetation. During the winter season both conditions are practically eliminated.

The definition of the control section implies that the elevation of the water at all gaging stations is controlled by some section below the gage. Since at stations with permanent control the only important factor in the change of the relation between winter stage and discharge is ice at the control section, changes in the rating curve can as a rule be studied by considering the effect of ice in the immediate vicinity of the control section.

The different forms of ice affect the relation between stage and discharge in much the same way, and as they are often associated with each other the factors covered by each form can not be wholly distinguished. Their tendencies, however, can be partly discussed.

\footnotetext{
1 The importance of control sections in stream-gaging work was first brought to the attention of engineers by M. R. Hall, formerly district engineer for the United States Geological Survey in the Southeastern States.
} 


\section{SURFACE ICE.}

GENERAL EFFECTS.

Surface ice may appear at the control section as (1) complete cover in flotation; (2) complete cover bridged across, free from or partly :upported by the water; (3) partial cover, usually in flotation; (4) jams due to piling up of ice; or (5) alternate layers of ice and water.

The first result of surface freezing is to displace air by ice, thereby increasing the total friction, as the friction of water flowing in contact with ice is greater than that of water in contact with air. The second result is to diminish the effective cross section of the stream by displacing a portion of the water. Therefore, with the formation of an ice cover and a constant flow, there will be either an increase in slope or increase in cross section. As the slope can increase only slightly, the general .effect will be to increase the stage. In general, it may be said that ice on a stream tends to increase the stage for a given discharge, the amount of increase depending on the quantity of ice at the control section. Discharge measurements of ice-covered streams will therefore always plot either on the curve or at the left; under no circumstances will they plot to the right of the open-water curve if the measurements truly represent the discharge at the time they were made; and the curve used represents the true flow over the control section, independent of the effect of ice.

As the specific gravity of ice is lower than that of water and its tensile strength is rather low, ice is generally in flotation, except on small streams where it may be bridged across. If the ice is bridged at the control in such a way that the surface of the ice is not in contact with the water the ice will not affect the flow at the gage.

Surface ice will therefore affect the gage heights by amounts dependent on its quantity at the control section. The exceptions to this rule occur when ice jams are formed either between the control section and the gage, or below the section to such an extent as to drown out the control section; in either case a new temporary control is formed by the ice jams.

EFFECT ON DISTRIBUTION OF VELOCITIES IN THE VERTICAL.

The effect of surface ice on the distribution of velocities in the cross section was discussed by Barrows and Horton in their report on the determination of stream flow during the frozen season. ${ }^{1}$ Under the theories therein outlined and since confirmed, the approximate mean velocity in the vertical may be ascertained by taking the mean of the observed relocities at 0.2 and 0.8 depths beneath the ice. The average position of maximum velocity is at 0.37 depth below the ice. The average coefficient for determining the mean velocity from the velocity at mid-depth is found to be 0.878 , but as 
this coefficient has been found to range from 0.70 to unity, it is advisable to make specific determinations for each section under consideration. The general distribution of velocity in the horizontal and vertical under complete ice cover is shown in figure 7 .

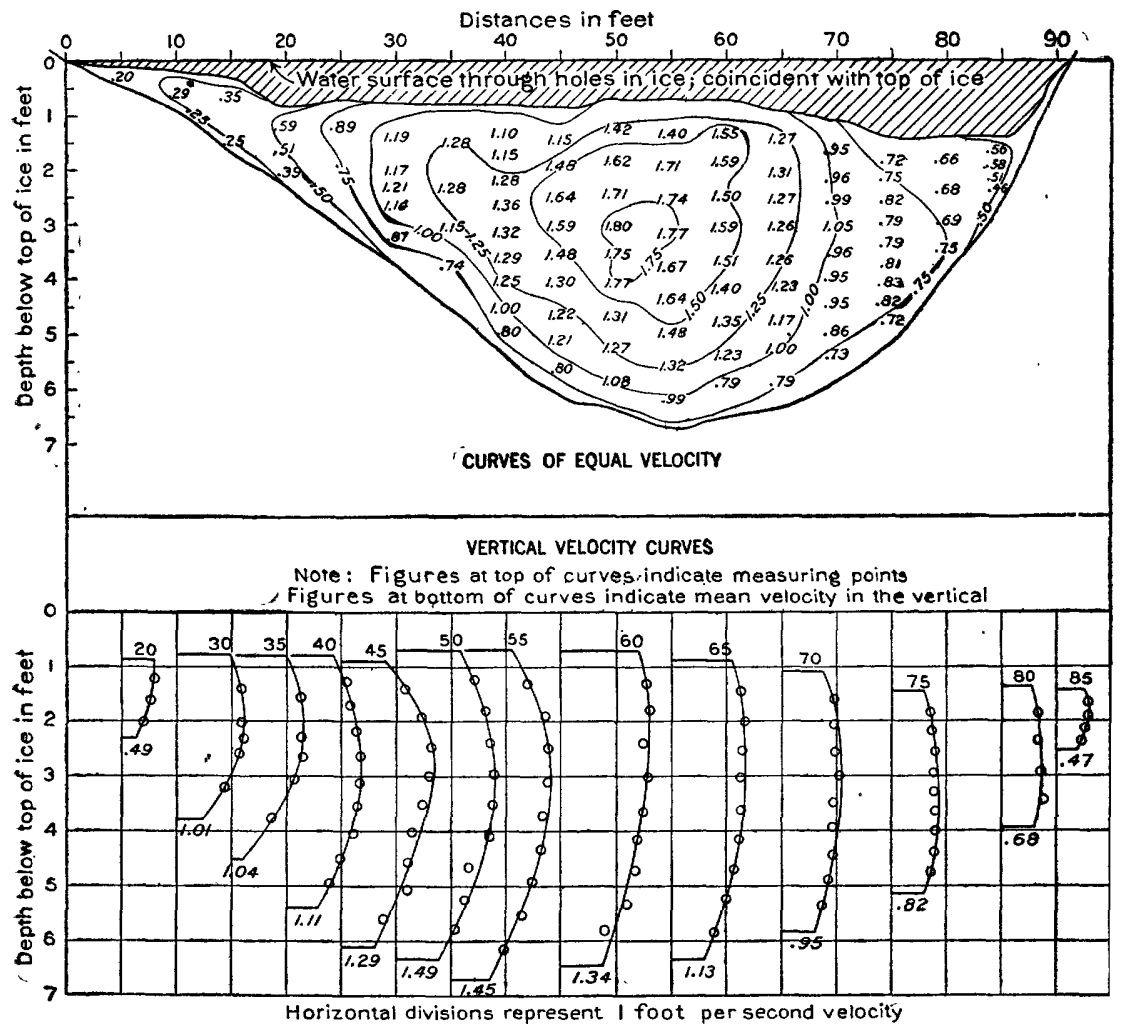

Frgure 7.-Diagram showing distribution of horizontal and vertical velocities under com. plete ice cover: Cannon River at Welch, Minn.

\section{GAGING-STATION STUDIES.}

VALUE OF WORK.

Of the three varieties of ice-surface, frazil, and anchor-surface ice is the most common and its effect is evident on the gages at $\delta$ larger number of stations than is the effect of the other two. The relative value of readings of gage heights to water surface and gage heights to the under surface of the ice as a basis for computation of winter discharge has been much discussed, but, owing to the difficulty in accurately determining both the mean gage height to the bottom of the ice and the position of the control section, it is doubtful if the available data are sufficient to settle the question.

In a study ${ }^{1}$ of winter records made at 14 gaging stations to obtain a coefficient for computing the flow of an ice-covered stream from

${ }^{1}$ Adams, C. R., Determination of stream flow during the frozen season: Eng. News, จol. 65, pp. 124-126, Feb. 2, 1911. 
its open-channel rating curve, $C$ was used to represent the coefficient with gage heights to water surface and $C^{\prime}$ the coefficient with gage heights to bottom of ice. The application of the coefficients to com$p$ uted discharges apparently showed that the range in the variation of $C$ was less than the range in the variation in $C^{\prime}$, but at 5 stations the total range in $C^{\prime}$ was less than that of C. No attempt was made to group stations at which average distance from water surface to bottom of ice was taken at the control.

The cross section of an ice-covered stream (fig. 8) shows the position of the water surface in a hole cut in the ice and the approximate position the water surface would hold were there no ice at the control section; $d$ is the distance through which

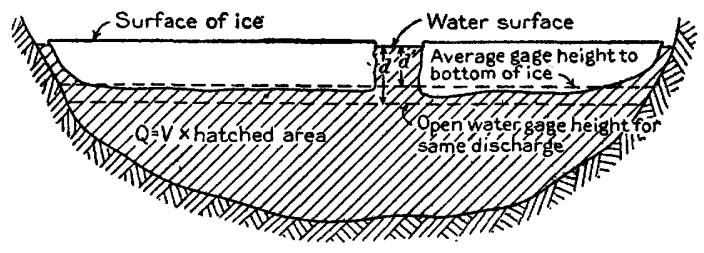

CROSS SECTION OF STREAM HAVING ICE COVER IN FLOTATION.

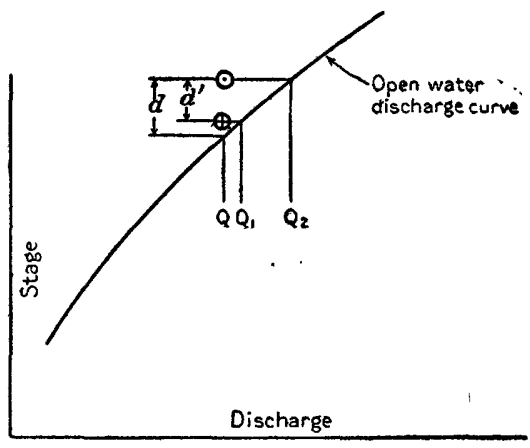

MEASUREMENTS PLOTTED FOR THE ABOVE CONDITIONS

- Measurements plotted for gage height to water surface $\oplus$ Measurements plotted for gage height to under surface of ice"

$$
\begin{aligned}
& C=Q \div Q_{2}=1.00 \text { or less } \\
& C^{\prime}=Q \div Q_{1}= \pm 1.00 \\
& \text { For ideal station - } \\
& d=0 \\
& c=1.00
\end{aligned}
$$

Figure 8.-Typical cross section of and rating curve for an ice-covered stream.

the water surface is raised by the ice, flow being constant; and $d^{\prime}$ is the distance from the water surface as it stands in a hole cut in the ice to the average under surface of the ice. The winter measurements are plotted with respect to the open-water rating curve: $Q$ is the measured discharge, $Q_{1}$ the result obtained by applying to the open-water curve the gage height to the under surface of the ice, and $Q_{2}$ the result obtained with gage heights of the water surface through a hole cut in the ice. With an open control section $Q$ will equal $Q_{2}$, and $d$ will equal zero. In computing flow affected by surface ice the problem is to determine $d$, which will always equal zero or be a positive quantity.

$$
17020^{\circ}-\text { wsP } 337-13-3
$$


As the only appreciable effect of ice results from its presence at the control section, data to determine the value of gage heights to bottom of ice, which may be useful for certain stations, should be collected at that section, but for most stations gage heights to the water surface are preferable for the following reasons:

1. The effect of ice at the control section on the readings of gage heights to water surface is always positive; that is, the ice backs the water up at the gage so that the readings are higher than they would be for the same discharge in open channels.

2. Gage heights to water surface are more easily and accurately determined than those to the under surface of the ice, as it is necessary to cut through the ice only at the gage. The gage height to the under surface of the ice is obtained by cutting a large number of holes and computing the average depth from the water surface to the bottom of the ice; the results, because of irregularity of the ice and fluctuation of water in the holes, are of necessity only approximate.

3. The position of the control section is uncertain.

\section{ELK RIVER NEAR BIG LAKE, MINN.}

The gage on Elk River near Big Lake is on a pile a few feet above the bridge. During the greater part of the winter ice does not form within a few feet of the gage, doubtless because of the effect of inflow from a spring. The control section is not well defined but it is probably about 200 feet below the gage. The current-meter measurements have been made at a section about 300 feet below the gage where conditions are more favorable than at either the gage or the control section. The results of winter measurements made in 1911-12 and 1912-13 are given in the following table:

Discharge measurements, Elk River near Big Lake, Minn., during 1911-12 and 1912-13, and relation $C$ and $C^{\prime}$.

\begin{tabular}{|c|c|c|c|c|c|c|c|c|c|}
\hline \multirow{2}{*}{ Date. } & \multirow{2}{*}{$\begin{array}{l}\text { Ice } \\
\text { thick- } \\
\text { ness. }\end{array}$} & \multirow{2}{*}{$\begin{array}{l}\text { Water } \\
\text { surface } \\
\text { to top } \\
\text { of ice. }\end{array}$} & \multicolumn{2}{|c|}{ Gage height } & \multirow{2}{*}{$\begin{array}{l}\text { Meas- } \\
\text { ured } \\
\text { dis- } \\
\text { charge. }\end{array}$} & \multicolumn{2}{|c|}{$\begin{array}{l}\text { Gage height to } \\
\text { water surface. }\end{array}$} & \multicolumn{2}{|c|}{$\begin{array}{l}\text { Gage height to } \\
\text { bottom of ice. }\end{array}$} \\
\hline & & & $\begin{array}{c}\text { Water } \\
\text { surface. }\end{array}$ & $\begin{array}{l}\text { Bottom } \\
\text { of ice. }\end{array}$ & & $\begin{array}{c}\text { Dis- } \\
\text { charge. }\end{array}$ & C. & $\begin{array}{c}\text { Dis- } \\
\text { charge. }\end{array}$ & $C^{\prime}$. \\
\hline 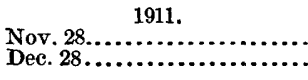 & $\begin{array}{r}\text { Feet. } \\
0.36 \\
.55\end{array}$ & $\begin{array}{l}\text { Feet. } \\
.0 \\
.0\end{array}$ & $\begin{array}{l}\text { Feet. } \\
0.98 \\
1.08\end{array}$ & $\begin{array}{l}\text { Feet. } \\
0.62 \\
.53\end{array}$ & $\begin{array}{r}\text { Sec. }-f t . \\
96 \\
106\end{array}$ & $\begin{array}{r}\text { Sec.-ft. } \\
195 \\
224\end{array}$ & $\begin{array}{r}0.49 \\
.47\end{array}$ & $\begin{array}{r}S e c . f t . \\
105 \\
85\end{array} \mid$ & $\begin{array}{l}0.92 \\
1.25\end{array}$ \\
\hline 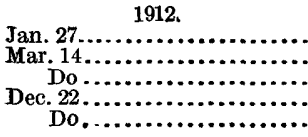 & $\begin{array}{l}.92 \\
.77 \\
.77 \\
.60 \\
.60\end{array}$ & $\begin{array}{l}.09 \\
.02 \\
.02 \\
.0 \\
.0\end{array}$ & $\begin{array}{r}.97 \\
1.34 \\
1.34 \\
.84 \\
.84\end{array}$ & $\begin{array}{l}.14 \\
.59 \\
.59 \\
.24 \\
.24\end{array}$ & $\begin{array}{l}39 \\
73 \\
72 \\
94 \\
95\end{array}$ & $\begin{array}{l}192 \\
305 \\
305 \\
158 \\
158\end{array}$ & $\begin{array}{l}.20 \\
.24 \\
.24 \\
.59 \\
.59\end{array}$ & $\begin{array}{l}16 \\
98 \\
98 \\
31 \\
31\end{array}$ & $\begin{array}{r}2.24 \\
.74 \\
.74 \\
3.00 \\
3.00\end{array}$ \\
\hline $\begin{array}{r} \\
\text { Jan. } 28 \ldots \ldots \ldots \ldots \\
\text { Do } \ldots \ldots \ldots \ldots \ldots \\
\text { Feb. } 25 \ldots \ldots \ldots \ldots \\
\text { Mar. } 18 a \ldots \ldots \ldots \ldots\end{array}$ & $\begin{array}{l}.89 \\
.89 \\
.68\end{array}$ & $\begin{array}{l}.05 \\
.05 \\
.0\end{array}$ & $\begin{array}{l}1.24 \\
1.24 \\
1.32 \\
1.85\end{array}$ & $\begin{array}{l}.40 \\
.40 \\
.54\end{array}$ & $\begin{array}{r}55 \\
57 \\
69 \\
198\end{array}$ & $\begin{array}{l}273 \\
273 \\
298\end{array}$ & $\begin{array}{l}.20 \\
.21 \\
.23\end{array}$ & $\begin{array}{l}58 \\
58 \\
87\end{array}$ & $\begin{array}{r}.95 \\
.99 \\
.79\end{array}$ \\
\hline
\end{tabular}

a Made 1,000 feet above gage; 40 per cent ice cover at control; 35 per cent ice cover at measuring section. 
The thickness of ice and the distance from water surface to bottom of ice were determined at each measurement, so that the gage height to the under surface of the ice can be computed. The open-water discharge, as shown by the station rating curve, is given for the two gage heights and the coefficient $C$ and $C^{\prime}$. It will be noted that the

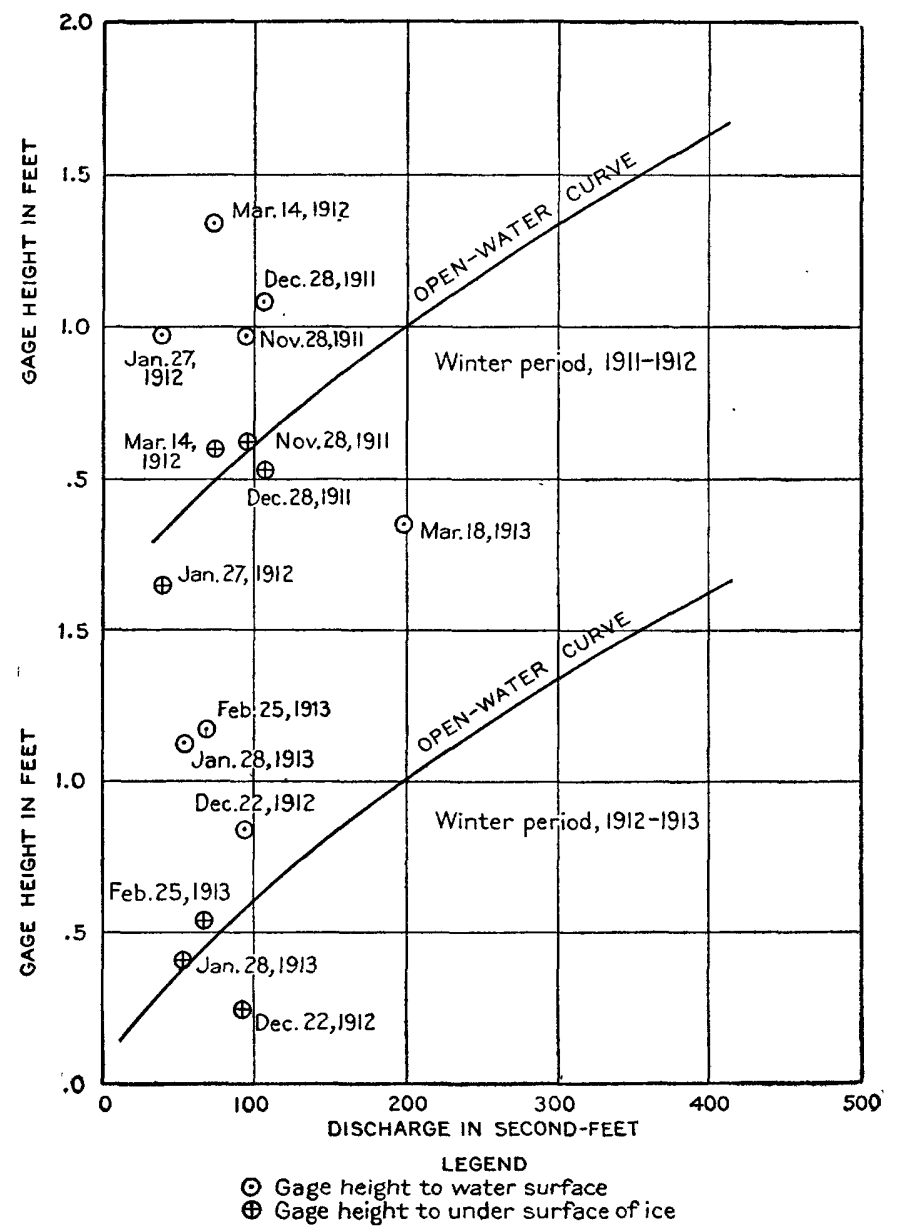

FIGURE 9.-Relation between open-water curve and ice measurements: Elk River near Big Lake, Minn.

values of $C$ are all less than unity, ranging from 0.20 to 0.59 , while $C^{\prime}$ ranges from 0.74 to 3.00 .

The data in the table are presented graphically in figure 8 . The diagram shows an entire lack of conformity between the plotted points, whether gage heights are read to water or to the under surface of the ice. The measurements, although not made at the control 
section, were probably made as close to it as most ice measurements are made at stations now established, and no curve could be drawn through the plotted points to which might be applied the uncorrected gage heights, and the discharge thus determined.

\section{CROW WING RIVER AT PILlAage, MIINN.}

The gage on Crow Wing River is about 11 miles above the confluence of that stream with the Mississippi River. The natural slope and cross sections of the river were nearly uniform from the gage to the mouth, the slope being about 2.6 feet per mile, without decided breaks, but the uniformity has now been destroyed by a dam. Probably the control section for the station is a long stretch of the river bed below the gage. Except in stretches within the influence of occasional springs and of ground water coming in along the banks, the ice forms to a practically uniform thickness, both across and lengthwise the river, so that the average distance from the water surface to the under surface of the ice would be approximately the same at all points near the gage. The results of measurements made at this station during the winter periods of 1911-12 and 1912-13 are given in the following table and are shown graphically by figure 10.

Discharge measurements, Crow Wing River at Pillager, Minn., during 1911-12 and 1912-13, and relation $C$ and $C^{\prime}$.

\begin{tabular}{|c|c|c|c|c|c|c|c|c|c|}
\hline \multirow{2}{*}{ Date. } & \multirow{2}{*}{$\begin{array}{l}\text { Ice } \\
\text { thick- } \\
\text { ness. }\end{array}$} & \multirow{2}{*}{$\begin{array}{l}\text { Water } \\
\text { surface } \\
\text { to } \\
\text { top of } \\
\text { ice. }\end{array}$} & \multirow{2}{*}{$\begin{array}{c}\text { Gage } \\
\text { height } \\
\text { to } \\
\text { water } \\
\text { surface. }\end{array}$} & \multirow{2}{*}{$\begin{array}{c}\text { Gage } \\
\text { height } \\
\text { bottom } \\
\text { of ice. }\end{array}$} & \multirow{2}{*}{$\begin{array}{c}\text { Meas- } \\
\text { ured } \\
\text { dis- } \\
\text { charge. }\end{array}$} & \multicolumn{2}{|c|}{$\begin{array}{l}\text { Gage height to } \\
\text { water surface. }\end{array}$} & \multicolumn{2}{|c|}{$\begin{array}{l}\text { Gage height to } \\
\text { bottom of ice. }\end{array}$} \\
\hline & & & & & & $\begin{array}{c}\text { Dis- } \\
\text { charge. }\end{array}$ & c. & $\begin{array}{c}\text { Dis- } \\
\text { charge. }\end{array}$ & $\mathbf{C}^{\prime}$ \\
\hline Dec. $15 \ldots . . . \ldots \ldots$. & $\begin{array}{l}\text { Feet. } \\
0.80\end{array}$ & $\begin{array}{l}\text { Feet. } \\
0.75\end{array}$ & $\begin{array}{l}\text { Feet. } \\
6.22\end{array}$ & $\begin{array}{c}\text { Feet. } \\
5.47\end{array}$ & $\begin{array}{r}\text { Sec.-ft. } \\
476\end{array}$ & $\begin{array}{l}\text { Sec.-ft. } \\
1,089\end{array}$ & 0.44 & Sec.-ft. & 0.80 \\
\hline $\begin{array}{l} \\
\text { Jan. } 24 \ldots 12 . \\
\text { Feb. } 28 \ldots \ldots \ldots \\
\text { Dec. } 18 \ldots \ldots \ldots \ldots\end{array}$ & $\begin{array}{r}1.14 \\
1.34 \\
.74\end{array}$ & $\begin{array}{r}1.06 \\
1.32 \\
.74\end{array}$ & $\begin{array}{l}6.22 \\
6.54 \\
6.14\end{array}$ & $\begin{array}{l}5.16 \\
5.22 \\
5.40\end{array}$ & $\begin{array}{l}326 \\
368 \\
440\end{array}$ & $\begin{array}{r}1,089 \\
1,342 \\
895\end{array}$ & $\begin{array}{l}.30 \\
.27 \\
.49\end{array}$ & $\begin{array}{l}438 \\
467 \\
440\end{array}$ & $\begin{array}{r}.74 \\
.74 \\
1.00\end{array}$ \\
\hline $\begin{array}{c}1913 . \\
\operatorname{Jan} .24 \ldots \ldots \ldots \ldots \ldots \\
\text { Feb. } 19 \ldots \ldots \ldots \ldots \ldots\end{array}$ & $\begin{array}{l}1.10 \\
1.40\end{array}$ & $\begin{array}{l}1.07 \\
1.32\end{array}$ & $\begin{array}{l}6.22 \\
6.47\end{array}$ & $\begin{array}{l}5.15 \\
5.15\end{array}$ & $\begin{array}{l}358 \\
344\end{array}$ & $\begin{array}{r}956 \\
1,140\end{array}$ & $\begin{array}{l}.37 \\
.30\end{array}$ & $\begin{array}{l}334 \\
334\end{array}$ & $\begin{array}{l}1.07 \\
1.03\end{array}$ \\
\hline
\end{tabular}


The diagram shows lack of conformity between the points of discharge as plotted with the gage heights to the water surface, but the discharge points determined with the gage heights to the under surface of the ice fall nearly in line with the openwater curve, a result to be expected, as they represent measurements plotted to the average gage height of the under surface of the ice at the control section.

RED RIVER NEAR GRAND FORKS, N. DAK.

The station on Red River is on the Northern Pacific Railroad bridge between Grand Forks, N. Dak., and East Grand Forks, Minn. The drainage area at this point is 25,000 square miles. Winter measurements have been made at this station. The results of

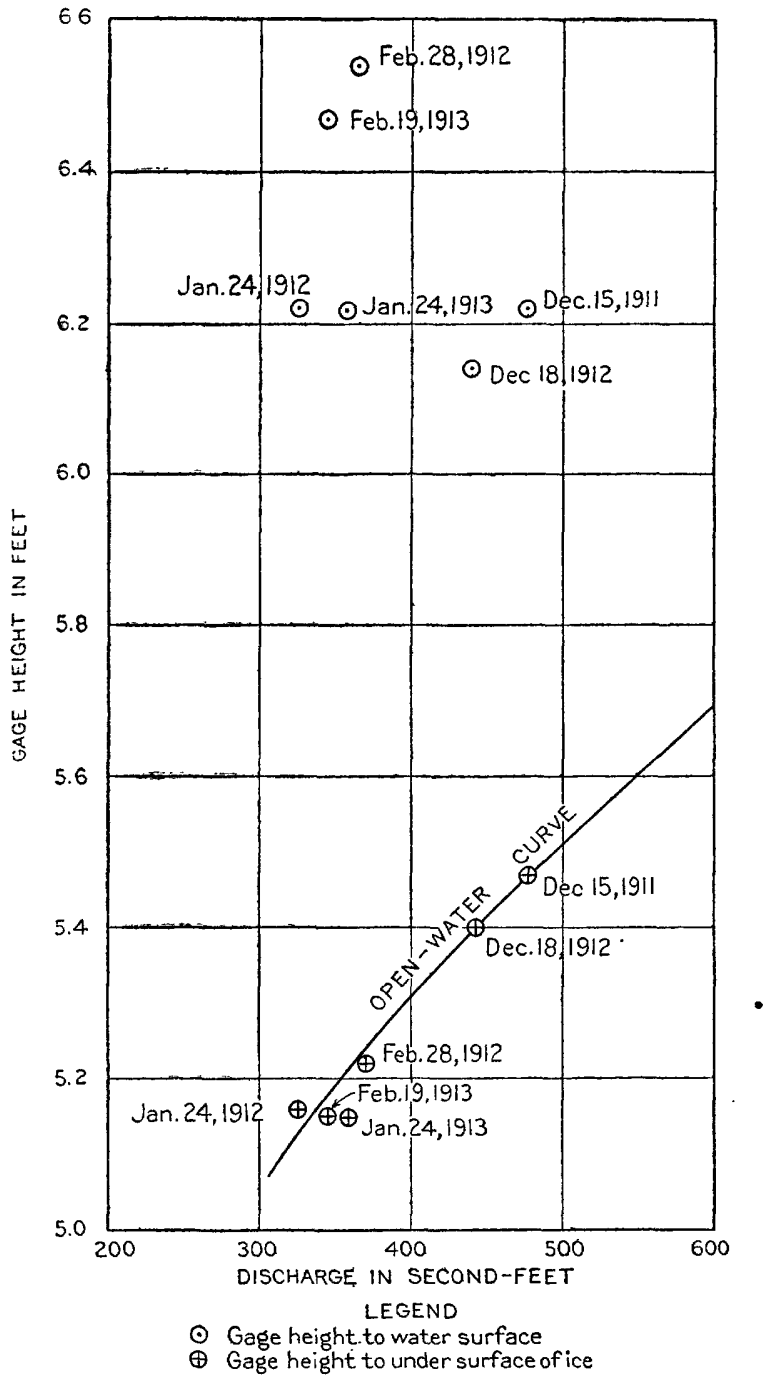

Figure 10.-Relation between open-water curve and ice measurements : Crow Wing River at Pillager, Minn. these measurements since 1905 are given in the following table and are also plotted in Plate III : 
Discharge measurements of Red River at Grand Forks, N. Dak., in 1905, 1906, 1907, 1908, 1909, 1910, 1911, 1912, and 1913, and relation $C$ and $C^{\prime}$.

\begin{tabular}{|c|c|c|c|c|c|c|c|}
\hline \multirow{2}{*}{ Date. } & \multirow{2}{*}{$\begin{array}{c}\text { Gage } \\
\text { height } \\
\text { water } \\
\text { surface. }\end{array}$} & \multirow{2}{*}{$\begin{array}{c}\text { Gage } \\
\text { height } \\
\text { bottom } \\
\text { of ice. }\end{array}$} & \multirow{2}{*}{$\begin{array}{l}\text { Meas- } \\
\text { ured dis- } \\
\text { eharge. }\end{array}$} & \multicolumn{2}{|c|}{$\begin{array}{l}\text { Gage height to } \\
\text { water surface. }\end{array}$} & \multicolumn{2}{|c|}{$\begin{array}{c}\text { Gage height to } \\
\text { bottom ice. }\end{array}$} \\
\hline & & & & $\begin{array}{c}\text { Dis- } \\
\text { charge. }\end{array}$ & C. & $\begin{array}{c}\text { Dis- } \\
\text { charge. }\end{array}$ & $\mathrm{C}^{\prime}$ \\
\hline $\begin{array}{l}1905 . \\
\cdots \cdots . .\end{array}$ & $\begin{array}{l}\text { Feet. } \\
9.05\end{array}$ & $\begin{array}{l}\text { Feet. } \\
\quad 8.02\end{array}$ & $\begin{array}{r}\text { Sec.-feet. } \\
1,840\end{array}$ & $\begin{array}{r}\text { Sec.-feet. } \\
2,660\end{array}$ & 0.69 & $\begin{array}{r}\text { Sec.-feet. } \\
2,090\end{array}$ & 0.88 \\
\hline 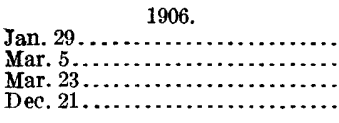 & $\begin{array}{r}9.45 \\
9.51 \\
10.24 \\
8.59\end{array}$ & $\begin{array}{l}7.79 \\
7.01 \\
7.82 \\
7.71\end{array}$ & $\begin{array}{l}1,771 \\
1,554 \\
1,881 \\
1,698\end{array}$ & $\begin{array}{l}2,890 \\
2,930 \\
3,370 \\
2,400\end{array}$ & $\begin{array}{l}.61 \\
.53 \\
.56 \\
.71\end{array}$ & $\begin{array}{l}1,980 \\
1,940 \\
1,990 \\
1,940\end{array}$ & $\begin{array}{l}.90 \\
.84 \\
.94 \\
.88\end{array}$ \\
\hline $\begin{array}{l}1907 . \\
\text { Jan. } 28 \ldots \ldots \ldots \ldots \ldots \\
\text { Mar. } 4 \ldots \ldots \ldots \ldots \ldots \ldots\end{array}$ & $\begin{array}{l}8.07 \\
8.18\end{array}$ & $\begin{array}{l}6.74 \\
6.68\end{array}$ & $\begin{array}{l}1,177 \\
1,216\end{array}$ & $\begin{array}{l}2,120 \\
2,180\end{array}$ & $\begin{array}{l}.56 \\
.56\end{array}$ & $\begin{array}{l}1,480 \\
1,460\end{array}$ & $\begin{array}{l}.80 \\
.83\end{array}$ \\
\hline $\begin{array}{c}1908 . \\
\text { Jan. } 20 \ldots \ldots \ldots \ldots \ldots \ldots \\
\text { Mar. } 9 \ldots \ldots \ldots \ldots \ldots \ldots \ldots\end{array}$ & $\begin{array}{l}6.76 \\
7.76\end{array}$ & $\begin{array}{l}5.57 \\
5.89\end{array}$ & $\begin{array}{l}912 \\
924\end{array}$ & $\begin{array}{l}1,490 \\
1,960\end{array}$ & $\begin{array}{r}.61 \\
.47\end{array}$ & $\begin{array}{l}1,080 \\
1,190\end{array}$ & $\begin{array}{l}.84 \\
.78\end{array}$ \\
\hline $\begin{array}{l}1909 . \\
\text { Jan. } 25 \ldots \ldots \ldots \ldots \ldots \\
\text { Feb. } 15 \ldots \ldots \ldots \ldots \ldots \ldots \\
\text { Nov. } 23 \ldots \ldots \ldots \ldots \ldots\end{array}$ & $\begin{array}{l}6.50 \\
6.15 \\
7.78\end{array}$ & $\begin{array}{l}4.67 \\
4.39 \\
7.34\end{array}$ & $\begin{array}{r}677 \\
592 \\
1,482\end{array}$ & $\begin{array}{l}1,220 \\
1,270 \\
1,970\end{array}$ & $\begin{array}{l}.55 \\
.47 \\
.75\end{array}$ & $\begin{array}{r}818 \\
740 \\
1,760\end{array}$ & $\begin{array}{l}.83 \\
.80 \\
.84\end{array}$ \\
\hline 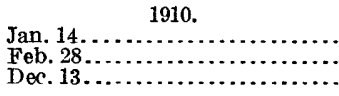 & $\begin{array}{l}8.77 \\
7.67 \\
3.74\end{array}$ & $\begin{array}{l}7.65 \\
5.88 \\
2.80\end{array}$ & $\begin{array}{r}1,530 \\
983 \\
312\end{array}$ & $\begin{array}{l}2,510 \\
1,910 \\
575\end{array}$ & $\begin{array}{l}.61 \\
.51 \\
.54\end{array}$ & $\begin{array}{l}1,900 \\
1,180 \\
356\end{array}$ & $\begin{array}{l}.81 \\
.84 \\
.88\end{array}$ \\
\hline 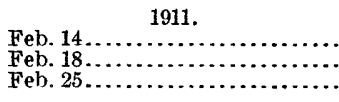 & $\begin{array}{l}4.10 \\
4.11 \\
4.33\end{array}$ & $\begin{array}{l}2.60 \\
2.48 \\
2.88\end{array}$ & $\begin{array}{l}198 \\
177 \\
235\end{array}$ & $\begin{array}{l}665 \\
668 \\
724\end{array}$ & $\begin{array}{l}.30 \\
.26 \\
.33\end{array}$ & $\begin{array}{l}312 \\
286 \\
374\end{array}$ & $\begin{array}{l}.64 \\
.62 \\
.62\end{array}$ \\
\hline 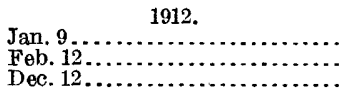 & $\begin{array}{l}3.50 \\
3.00\end{array}$ & $\begin{array}{l}2.41 \\
1.64\end{array}$ & $\begin{array}{l}175 \\
115\end{array}$ & $\begin{array}{l}515 \\
400\end{array}$ & $\begin{array}{l}.34 \\
.29 \\
52\end{array}$ & 272 & .64 \\
\hline $\begin{array}{l}\text { Jan. } 25 \ldots \ldots \ldots \ldots \ldots \\
\text { Mar. } 8 \ldots \ldots \ldots \ldots \ldots . .\end{array}$ & $\begin{array}{l}4.50 \\
3.90\end{array}$ & $\begin{array}{l}3.30 \\
2.48\end{array}$ & $\begin{array}{c}319 \\
196\end{array}$ & $\begin{array}{l}770 \\
615\end{array}$ & $\begin{array}{r}.41 \\
32\end{array}$ & $\begin{array}{l}469 \\
288\end{array}$ & $\begin{array}{r}.68 \\
.68\end{array}$ \\
\hline
\end{tabular}

The channel shifts somewhat, so that a new rating curve has been prepared each year, but the curve presented fits the entire series of measurements closely. Although neither the points plotted with gage heights to the water surface nor those plotted with gage heights to the bottom-of the ice follow any well-defined curve for winter periods considered separately, the entire series falls generally on two curves parallel to the open-water rating curve.

\section{ST. MARY RIVER NEAR BABB, MONT.}

The upper station on St. Mary River is near the dam site 1 mile below the outlet of lower St. Mary Lake and 1 mile above the mouth of Swiftcurrent Creek.

During the greater part of the winter the stream is frozen over at the gage and for a distance of about 100 yards below and 200 yards above, but the channel remains open at the outlet of the lake and at the control section below the gage throughout the winter. At times during periods of ice the channel in the center of the stream for about one-fourth of its width is open below the gage, but there is 


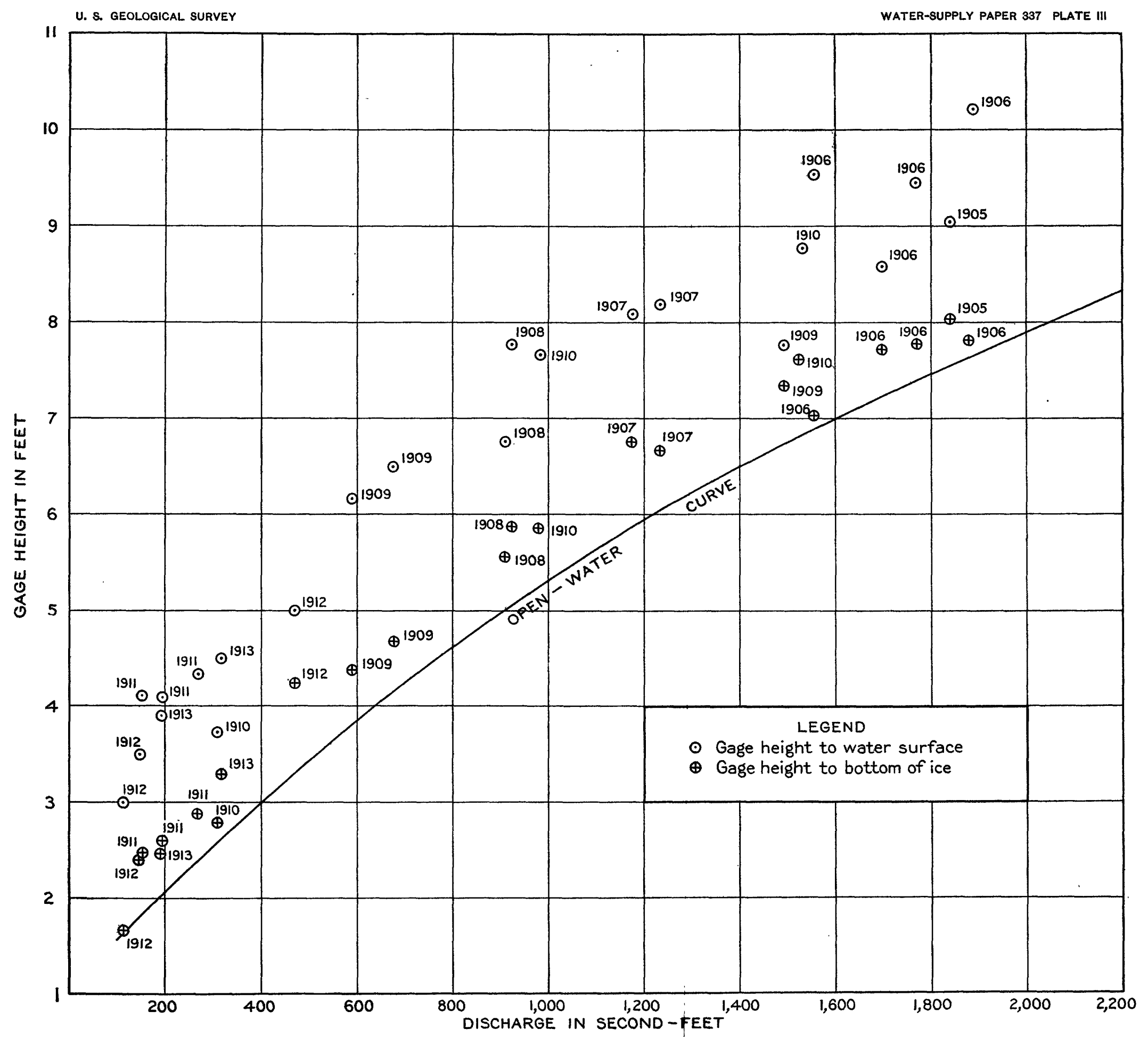

RELATION BETWEEN OPEN-WATER CURVE AND ICE MEASUREMENTS: RED RIVER AT GRAND FORKS, MINN. 
always heavy ice on the banks of the river. The channel opposite the gage is comparatively deep and sluggish. Four measurements made when ice was present below the gage gave the following results:

Winter discharge measurements on St. Mary River near Babb, Mont.

\begin{tabular}{|c|c|c|c|c|c|}
\hline Date. & width. & $\begin{array}{l}\text { Area of } \\
\text { section. }\end{array}$ & $\underset{\text { velocity. }}{\text { Mean }}$ & $\begin{array}{c}\text { Gage } \\
\text { height. }\end{array}$ & $\begin{array}{c}\text { Dis- } \\
\text { charge. }\end{array}$ \\
\hline 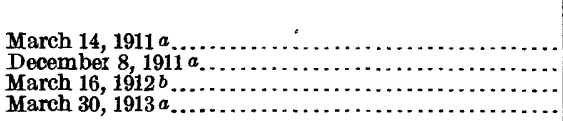 & $\begin{array}{r}\text { Feet. } \\
86 \\
62 \\
50 \\
76\end{array}$ & $\begin{array}{r}S q \cdot f t \\
69 \\
82 \\
33 \\
66\end{array}$ & $\begin{array}{r}\text { Ft.per sec. } \\
1.13 \\
1.05 \\
1.48 \\
1.30\end{array}$ & $\begin{array}{l}\text { Feet. } \\
0.93 \\
1.00 \\
.68 \\
1.00\end{array}$ & $\begin{array}{r}\text { Sec.-ft. } \\
79 \\
86 \\
49 \\
86\end{array}$ \\
\hline
\end{tabular}

$a$ Incomplete ice cover at gage.

$b$ Ice cover complete.

The relation between the open-water discharge curve and ice measurements is shown graphically in figure 11. The measurements apparently indicate that the ice has little, if any, effect on the rating curve so long as the lower control section is open and ice below the control section causes no backwater.

RAQUETTE RIVER AT PIERCEFIELD, N. $\mathbf{Y}$.

The gage on the Raquette at Piercefield is located one-half mile downstream from the plant of the International Paper Co. and about threefourths mile below Black Rapids. Between the dam and the

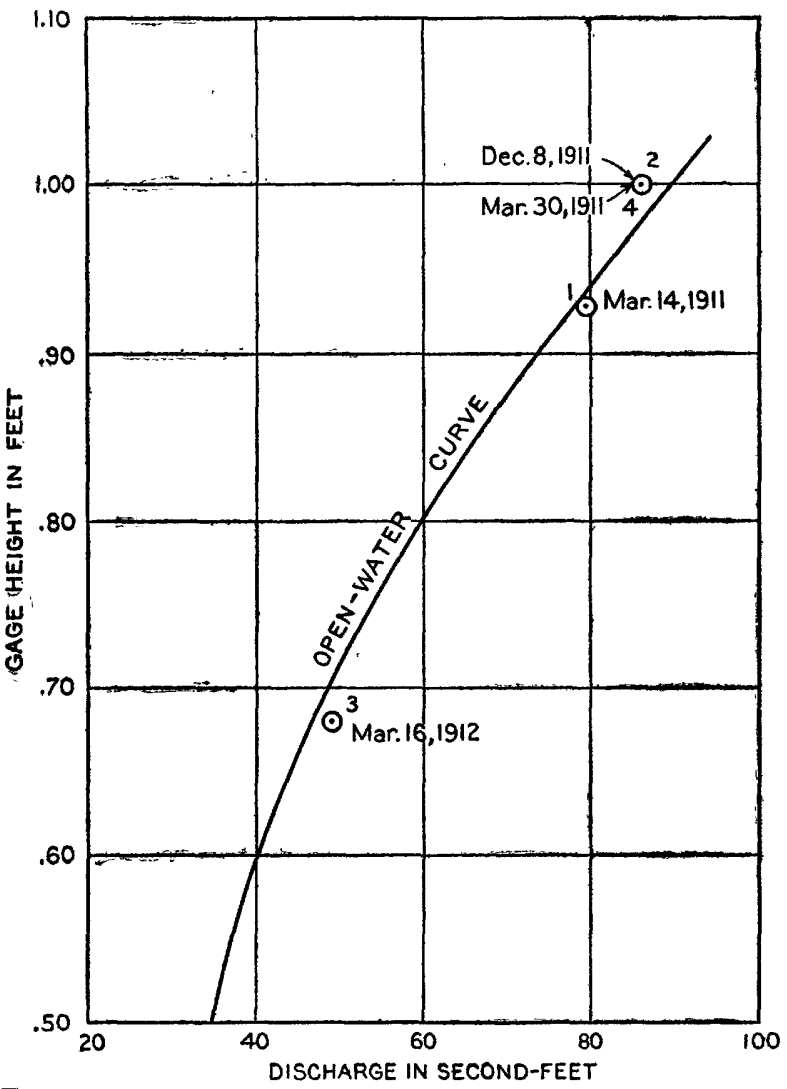

FIGUke 11.-Relation between open-water discharge curve and ice measurements: St. Mary River near Babb, Mont. head of the rapids the river freezes over annually to a depth of 1 to 2 feet. Ice rarely forms on the rapids, the crest of which is the control section for the gage. The open-water curve for this station, with the 
following discharge measurements plotted with the gage height to the water surface, is shown in figure 12.

Winter discharge measurements on Raquette River at Piercefield, N. Y.

\begin{tabular}{|c|c|c|c|c|c|}
\hline Date. & Width. & $\begin{array}{l}\text { Area of } \\
\text { section. }\end{array}$ & $\underset{\text { velocity. }}{\text { Mean }}$ & $\begin{array}{c}\text { Gage } \\
\text { height. }\end{array}$ & $\begin{array}{l}\text { Dis- } \\
\text { charge. }\end{array}$ \\
\hline 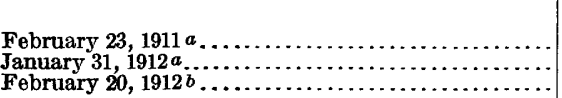 & $\begin{array}{r}\text { Feet. } \\
258 \\
268 \\
270\end{array}$ & $\begin{array}{r}S q . f t . \\
796 \\
1,180 \\
1,054\end{array}$ & $\begin{array}{r}\text { Ft.per sec. } \\
1.12 \\
.87 \\
.43\end{array}$ & $\begin{array}{l}\text { Feet. } \\
5.10 \\
5.38 \\
4.00\end{array}$ & $\begin{array}{r}\text { Sec.-ft. } \\
888 \\
1,030 \\
454\end{array}$ \\
\hline
\end{tabular}

a River completely open at control except for a little ice on rocks near shore.

$b$ Control free from ice.

It will be noticed that the measurements of February 23, 1911, and January 31, 1912, plot practically on the open-water curve, and that

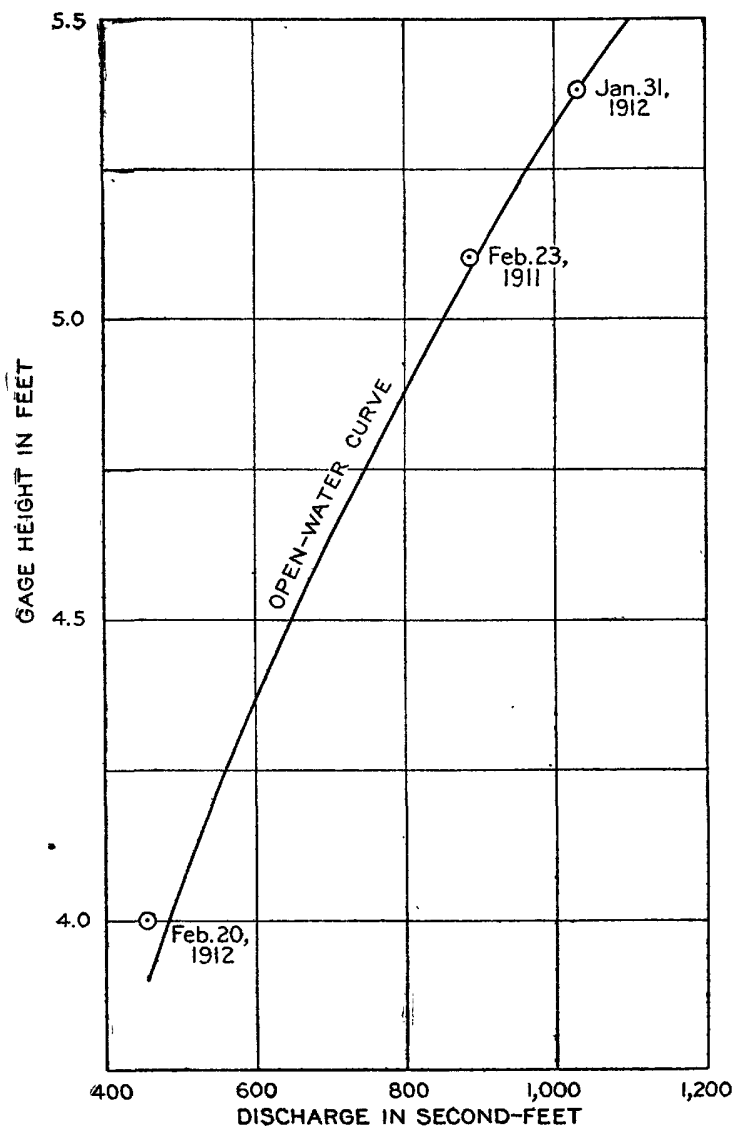

Figure 12.-Relation between open-water curve and ice measurements : Raquette River at Piercefield, N. Y. of February 20, 1913 . plots within 6 per cent of the curve, so that the open-water rating curve may be safely used to determine the winter discharge even for periods when ice may be present between the gage and control.

\section{FRAZIL.}

The presence of frazil in a stream makes the determination of discharge exceptionally difficult. Whether floating throughout the cross section of the stream in small quantities. compacted in large quantities either under ice or in the open, or lodged in connection with anchor ice, it tends to decrease the effective cross section of discharge and to raise the stage by an amount depending on its quantity. When carried with the current in small quantities 


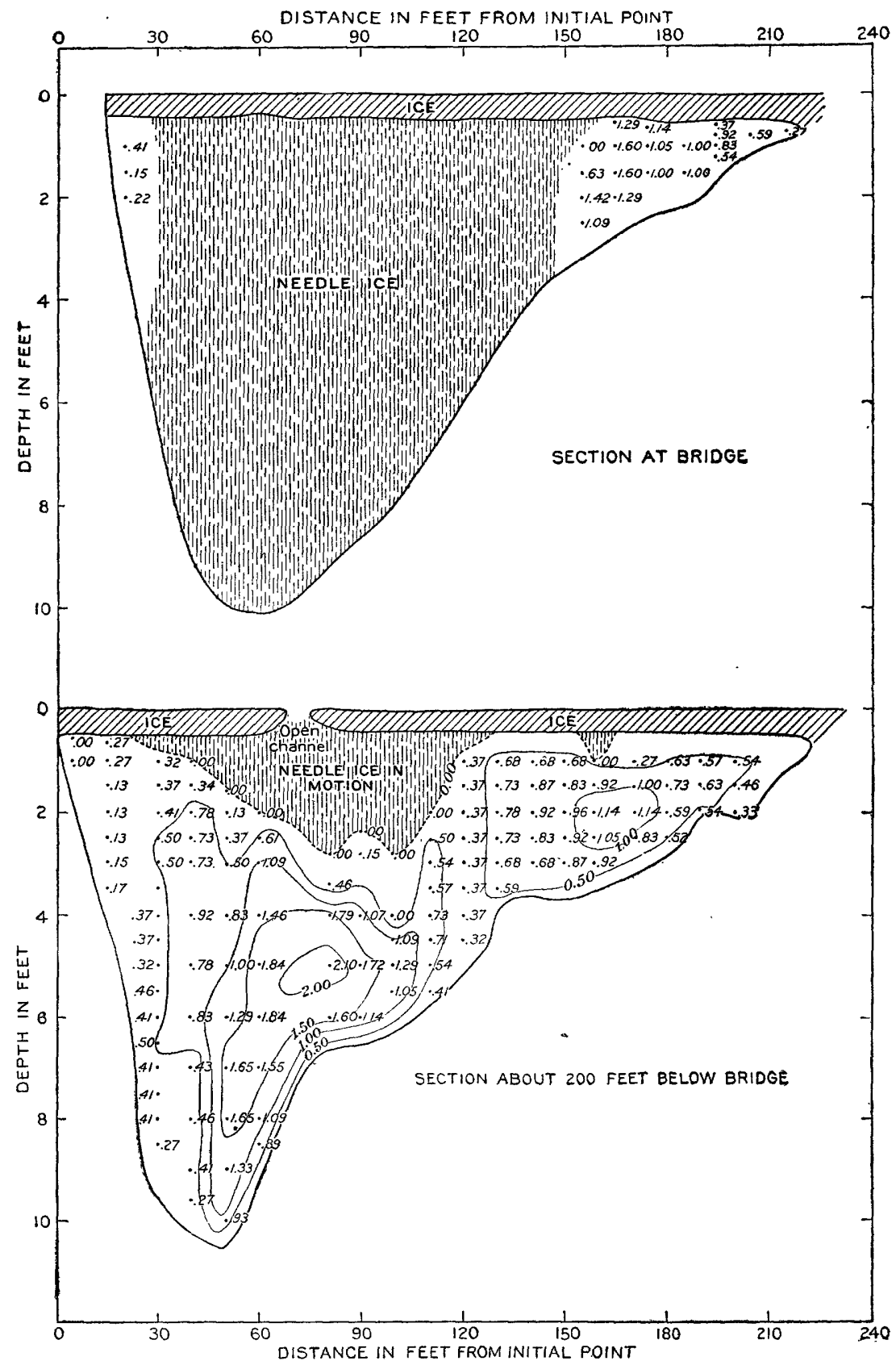

Figure 13.-Cross section of Chemung River at Chemung, N. Y., showing effect of needle ice or frazil. 
its effect on the stage is probably so slight that it can be ignored, though it may temporarily raise the stage at the control section. When, however, it is present in sufficient quantities to completely fill the channel it forms temporary jams that raise the water until the ice is overflowed or until the increased pressure pushes the frazil forward. The nucleus of these jams is probably anchor ice.

Because of the great difficulty in making discharge measurements when frazil is present, few examples are available. The general effect of frazil on cross sectional areas and velocities is, however, shown in the accompanying diagram ${ }^{1}$ (fig. 13).

At the upper section the channel underneath the surface ice was almost completely blocked by frazil or needle ice; at the lower section, 200 feet downstream, there was but little frazil, yet the observed velocities (shown by the figures) at the lower section were so great as to indicate considerable flow through the masses of frazil. The mean of the measured velocities is shown by the contours.

\section{ANCHOR ICE.}

GENERAL EFFECTS.

When attached to the bed of a river, anchor ice tends to raise the stage of the water in the stretch of channel above the point of its formation, and this backing up effect is increased when frazil becomes jammed in with the anchor ice. At a gage located above a decided ripple or rapid which in general remains open, the formation of anchor ice at the control section may have the same general effect as would the building of a submerged weir. In the absence of surface ice the effect of anchor ice on the gage heights can be closely determined by means of temperature records and frequent gage readings, as it is detached from the bed of the stream under the first warming influence of the sun.

The effect of anchor ice on stage and its relation to temperature is shown in studies of the records of Kootenai River near Libby, Mont., and of Schroon River near Riverbank, N. Y.

\section{GAGING-STATION STUDIES.}

KOOTENAI RIVER AT LIBBY, MONT.

The gaging station at Libby, Mont., was established by the Forest Service, in cooperation with the United States Geological Survey, October 13, 1910. A sketch of river in vicinity of the gages is given in figure 14.

1 From Barrows and Horton, Determination of stream flow during the frozen season: U. S. Geol. Survey Water-Supply Paper 187, p. 12, 1907. 


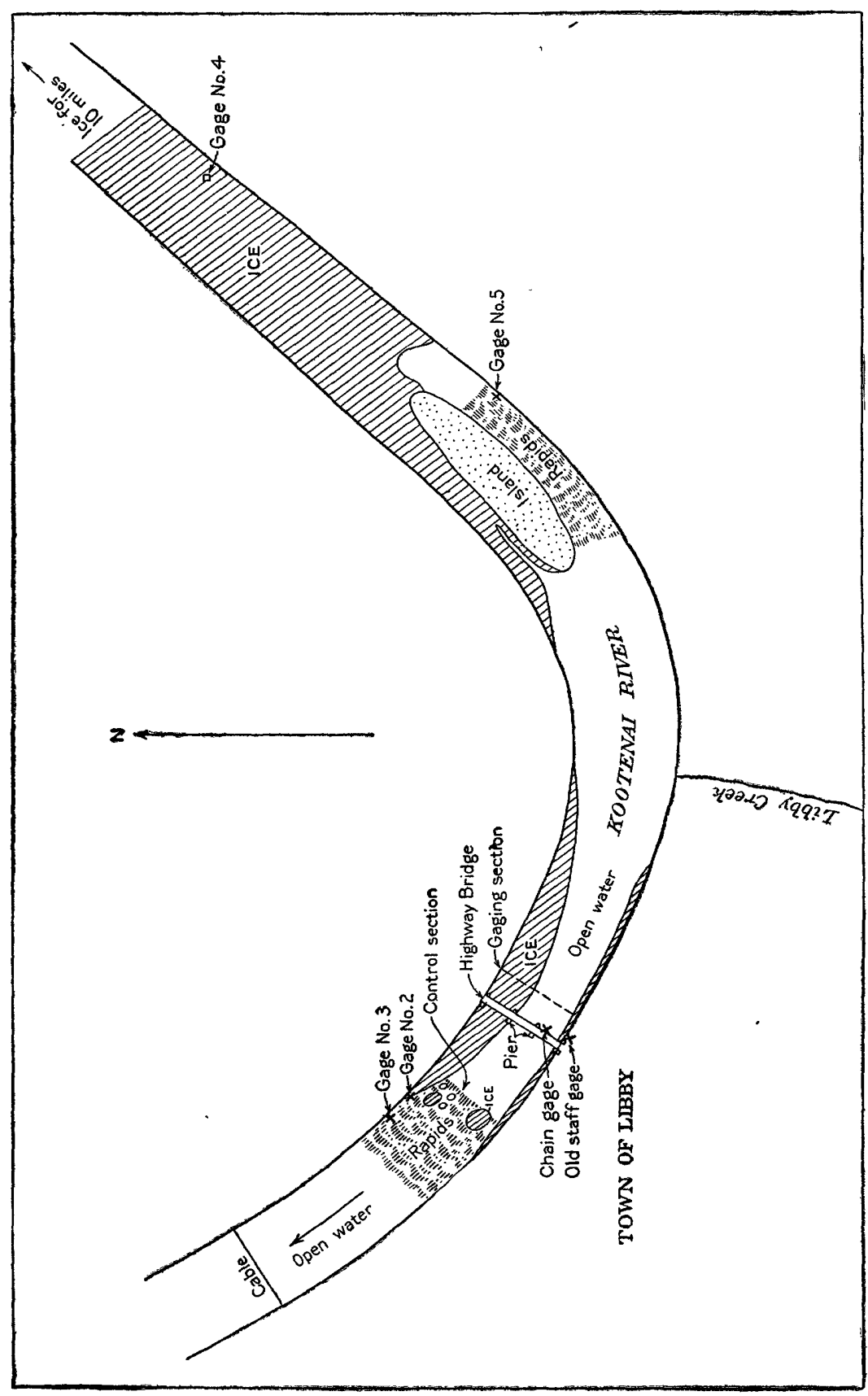


Measurements at this station were made from a car suspended from a ferry cable until 1912, when a bridge was built about 100 feet below the station and the ferry cable was removed. A good low-water rating curve has been developed for the station.

During the winter of 1912-13 measurements were made from a boat attached to a rope stretched across the river at the old cable section. Distances were marked off on a tag line stretched across the river just above the rope. At this section there was in the winter of 191213 an open channel 240 feet wide, and an ice-covered channel 80 feet wide on the right bank. The section contains a few large bowlders, but on the whole is good. The open section carried about 95 per cent of the discharge. There was considerable slush ice, and the temperature was sometimes below zero at the time of the measurements; but after placing the meter in the water it was not removed until the boat reached the opposite side of the river, where all the ice was located, so that the bearings and cups of the meter were not affected by ice. Except as affected by the small amount of water flowing under the ice, the measurements are probably as accurate as those commonly made in open channels, and an error as great as 10 per cent in the discharge under the ice-covered area would make an error of only one-half of 1 per cent in the total discharge.

The control section for the station is a riffle or rapid about 500 feet below the gage, and for some distance below the control section the stream is open throughout the winter. About $1 \frac{1}{2}$ miles above the station the channel is divided by an island. During low water practically the entire flow is in the channel on the left side of the island, where rapids occur. This channel remains open throughout the winter, as does also the greater portion of the channel between the island and the station. In the winter of 1912-13 the stream was frozen over for a distance of 10 miles above the island.

Discharge measurements were made daily from February 3 to February 20, and thereafter on alternate days up to March 13. A plot of the measurements from February 3 to 16 indicated that no definite relation existed between the temperature and the relation of gage height to discharge, though backwater at the gage, caused by anchor ice formed above the rapids at the control, apparently varied in a general way with the temperature.

An examination of the riffle at the control below the regular gage indicated that the stream was not greatly affected by anchor ice and that gage heights taken at a lower point might be more reliable. Therefore, on February 17, a secondary gage, called gage No. 2 (see fig. 14), was installed on the right bank at a point about 1,000 feet below the bridge. The new gage consisted of an iron pin graduated to tenths and driven into the gravel about 300 feet below the head of the rapids that form the control for the regular gage. At this point, 
and for a considerable distance below, the river is open the year round except for a little ice along the banks. The possibility that gage No. 2 might be affected by ice on the riffle just above, which might divert the water to one side or the other, led to the installation of a third gage (No. 3 on fig. 14), similar to No. 2, on the right bank about 200 feet farther downstream. This gage served only as a check on gage No. 2.

The cold wave during the latter part of February caused anchor ice, which on February 25 affected the stage at the regular gage by 0.49 foot. On the same date gage No. 2 fell 0.13 foot between morning and night, showing that it also was affected by ice to some extent.

The following are the readings of the two gages for the day:

Comparative readings of gages.

\begin{tabular}{|r|r|r|r|}
\hline \multicolumn{2}{|c|}{ Gage No. 1. } & \multicolumn{2}{|c|}{ Gage No. 2. } \\
\hline Time. & Feet. & \multicolumn{1}{|c|}{ Time. } & Feet. \\
9.00 a.m. & 3.01 & 9.10 a.m. & 2.93 \\
11.00 a.m. & 3.00 & 11.45 a.m. & 2.93 \\
12.00 noon & 2.95 & 1.15 p.m. & 2.90 \\
1.05 p.m. & 2.82 & 2.25 .m. & 2.81 \\
2.10 p.m. & 2.55 & 4.30 p.m. & 2.80 \\
4.50 p.m. & 2.52 & & \\
\hline
\end{tabular}

A similar change was observed every day when anchor ice was seen in the river-that is, a large variation between the morning and afternoon readings of gage No. 1 , and little, if any, variation in readings of gage No. 2 .

Attempts to find a place along the open section where anchor ice would not affect the gage readings were unsuccessful, but it was observed that no anchor ice formed under surface ice, even though the ice might be thin and the water sluggish. Therefore, on February 27 a fourth gage was installed about 2 miles above the bridge, where the river was completely frozen over, the ice extending for a distance of about 10 miles upstream. The stream at this point is deep and sluggish but there are rapids about one-fourth mile below the gage. Gage No. 4 was a pine staff driven into the bed of the stream through a hole in the ice 20 feet from the left bank and in about 5 feet of water. The ice was about 2 feet thick. The readings are affected not only by the surface ice at the gage but by surface ice that forms at the riffle below and blocks one channel (see fig. 14); they are not affected by anchor ice. The gage heights at No. 4 are slightly affected by the temperature, most of the variation being between morning and afternoon readings. A rise in stage appeared between morning and night and a fall during the night.

At temperatures as low as $13^{\circ}$ below zero no anchor ice formed at the open-water section at the riffle below gage No. 4, probably because the water coming from the stream under ice cover was at a slightly higher temperature. 
In order to study the fluctuations of the water surface at gage No. 4 and at the riffle below still another gage, No. 5, was installed on the left bank on March 2 a short distance below the ice-covered section and about $1 \frac{1}{2}$ miles above the regular gaging station. The channel at this point is divided by an island, but at low stages during the winter practically the entire flow of the stream is in the channel to the left of the island, where gage No. 5 was located. Libby Creek enters the Kootenai below gages Nos. 4 and 5 but above the station gage (No. 1) and gage No. 2. The variation in flow of Libby Creek, however, during the winter season is not more than 50 second-feet, so that it was disregarded (see fig. 14).

The closed-season readings of gage No. 5 differed from those of the open season because of conditions in the channel to the right of the island. During the winter this channel is practically closed by ice and most of the flow passes gage No. 5; but when the ice goes out the discharge is divided between the two channels, and the stage at gage No. 5 is decreased. A similar effect was noticed on gage No. 4, at which the stage was controlled by ice at the head of the riffle. Readings on gage No. 5 were less affected, however, than those on No. 4 , the total shift amounting to about 0.4 foot at No. 5, as against 1.2 feet at No. 4 . Readings on gage No. 2 were not affected by surface ice and were affected by anchor ice at a temperature of $-9^{\circ} \mathrm{F}$. by only about 0.13 foot, or 7 per cent. Readings on gage No. 3 were affected in the same way as those on gage No. 2, and the gage was not so well located. After it was found, therefore, that the gage heights at No. 2 were unaffected by surface ice gage No. 3 was discontinued.

Records kept during the period covered by the measurements indicate that temperature was the controlling factor affecting the gage heights, which were characterized by large and rapid fluctuations. The measurements made during February show that as a rule the discharge of the river changes slowly during the coldest weather. The sudden fluctuations in stage are due, first, to ice that forms at the control section, increases the height of water at the gage, and then goes out suddenly, causing a fall; and, second, to anchor ice which may cover the whole bottom of the river near the control section. The anchor ice forms during the night, and if the day following its formation is clear and the temperature is sufficiently high it will rise to the surface, causing great differences between morning and afternoon readings. When the weather is cloudy the anchor ice may remain at the bottom for one or more days and cause continued high gage heights.

On February 7 two measurements were made. At the beginning of the first measurement, in the morning, the gage reading was 0.7 foot and the discharge was found to be 2,160 second-feet. At the 


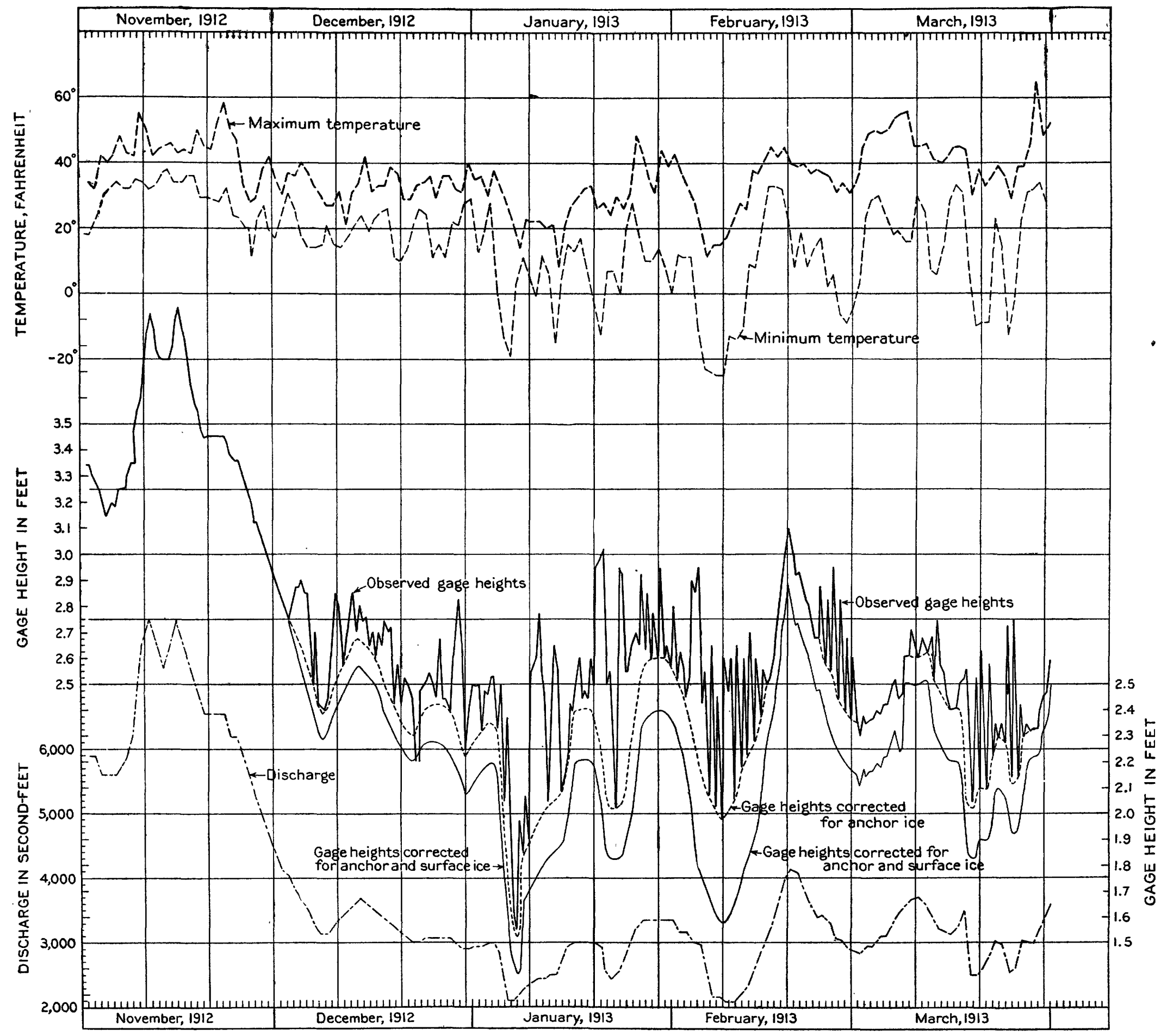

DIAGRAM SHOWING RELATION BETWEEN TEMPERATURE, GAGE HEIGHTS, AND DISCHARGE: KOOTENAI RIVER AT LIBBY, MONT. 
. 
end of the second measurement, in the afternoon, the gage read 0.09 foot and the discharge was found to be 2,180 second-feet. Thus during the day the gage height fell 0.61 foot, though the discharge remained practically constant.

The relation of daily discharge to gage height and temperature from November 1, 1912, to March 30, 1913, is illustrated on Plate IV, which shows a large daily fluctuation in the gage heights that corresponds very closely with the variations in temperature. The rise in the gage heights was caused by the formation of anchor ice; the fall was the result of its detachment and floating away. . The anchor ice would form during the night at temperatures below $14^{\circ}$ above zero and would cause a rise of as much as 0.6 or 0.7 foot on the gage; its going out, which usually began about noon, would cause a corresponding fall in stage; within a few hours it would nearly all disappear.

When a fall in gage height appeared while a discharge measurement was being made the gage height at the end of the measurement was adopted instead of the mean between beginning and end. The gage heights during the period when anchor ice existed were very unreliable, as conditions changed daily and in an irregular manner, whereas the gage heights observed after the anchor ice was out were affected only by the permanent backwater from surface ice.

The daily discharge for the period from December 1, 1912, to February 3,1913 , when no discharge measurements were made, was computed from the minimum gage heights as shown in outline on the gage-height diagram (Pl. IV), which doubtless represents approximately what would have been the gage heights if there had been no anchor ice.

The effect of backwater at the gage, aside from that caused by anchor ice, was estimated from the plotting of the measurements with reference to the open-water rating curve after February 3, 1913, and from December 1, 1912, to February 3, 1913, from observations of temperature and the amount of backwater on February 3, with the following results:

\begin{tabular}{ll|lr} 
Dec. 1 to 5 & Foot. & Foot. \\
Dec. 6 to 15 & & Feb. 4 to 16 \\
Dec. 16 to 23 & Feb. 17 to Mar. 5 & Mar. 6 to 12 \\
Dec. 24 to Jan. 7 & .15 & Mar. 13 to 28 & .3 \\
Jan. 8 to Feb. 3 &
\end{tabular}

By subtracting these amounts from the gage heights shown by the dotted line on the gage-height diagram (Pl. IV) the curve of effective gage height was obtained, to which the open-channel rating table was applied.

The gage-height curve apparently indicates that anchor ice did not form to such an extent in the early part of the winter as it did after 
February 1, and that most of the fluctuations were caused by ice that formed on the control during short periods and then went out suddenly.

SCHROON RIVER AT RIVERBANK, N? $\mathbf{Y}$.

The station on Schroon River near Riverbank, N. Y., was established September 2, 1907, by the United States Geological Survey in cooperation with the New York State Water Supply Commission. The records of maximum and minimum temperature, precipitation, original and corrected gage heights, and discharge at this station are compared in Plate V.

The discharge of Schroon River does not conform to all-changes in temperature, because the river has a large amount of natural storage in Schroon Lake. The records show that anchor ice generally formed whenever the minimum temperature fell below $10^{\circ} \mathrm{F}$. and that it usually left the river during the afternoon. The increase in backwater indicated during the period from February 5 to 17 was prob. ably caused by surface ice. The gradual decrease in the flow as the winter advances is natural.

\section{COMPUTATION OF FLOW OF FROZEN STREAMS.}

\section{METHODS AVAILABLE.}

The complex manner in which ice may form and the varying conditions presented by streams preclude the formulation of any method that can be universally employed to determine winter flow. In general the following methods may be used:

1. The readings of gage heights to the water surface may be directly applied to the open-water rating curve.

2. The observed gage heights may be applied directly to a special rating curve based on winter discharge measurements and gage heights to water surface.

3. Discharge measurements may be used in connection with gage heights and with data showing climatic conditions and the occurrence of ice. This method may be applied $(a)$ by the eye-that is. by inspecting the records of temperature, precipitation, and gage heights, estimating the daily discharge for the period between times of measurements, and adjusting the determinations by comparing: with results obtained at near-by stations; or $(b)$ graphically-by plotting the records of temperature, precipitation, and gage heights to water surface and determining the correction to the gage heights necessary to insure the applicability of the open-channel rating curve.

\section{FIRST METHOD.}

The use of the first method to determine the daily discharge of $\varepsilon$. frozen stream-the application of water-surface gage readings to 


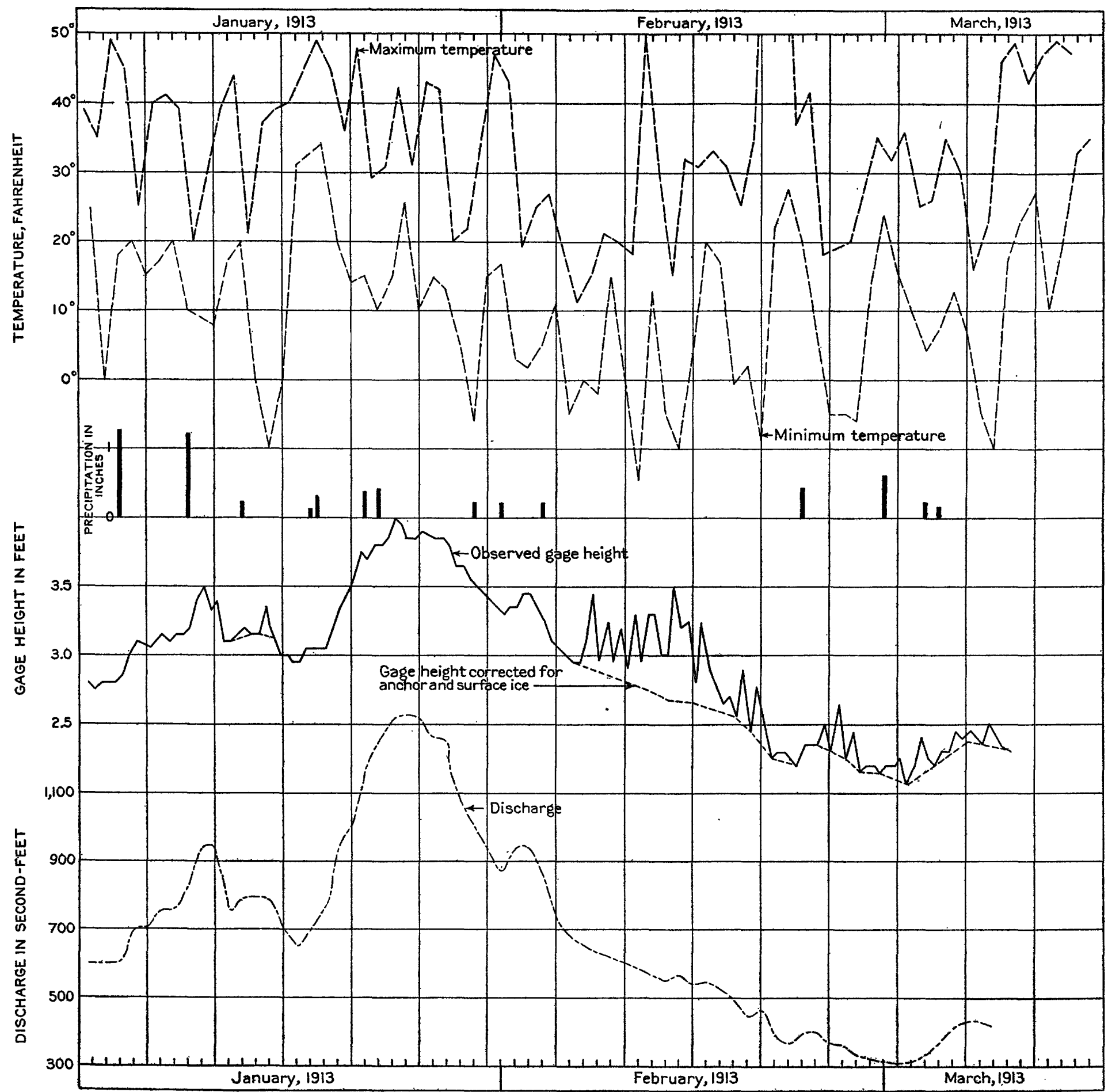

DIAGRAM SHOWING RELATION BETWEEN TEMPERATURE, GAGE HEIGHTS, AND DISCHARGE: SCHROON RIVER AT RIVERBANK, N. $Y$. 

the open-water rating curve-is advisable only when the stream is open at the control section and no backwater exists at the gage.

If the control section is entirely free from ice the relation between slope, stage, and discharge will not be appreciably changed even by complete ice cover between the control section and the gage. Attention was first directed to this fact in an article by C. R. Adams, ${ }^{1}$ who offered the following explanation:

Let it be assumed that a gage has been installed above the weir and a rating table obtained for open-channel conditions. A moment's reflection will show that this rating table is not affected by floating logs or other material in the pond above the weir; the reason being that gage heights are determined only by the height of water required at the weir to pass the discharge over this weir. If this floating material is ice it has no effect upon gage heights, so we can lay down the rule that under such conditions the open-water rating table will apply equally well where there is ice cover.

Unfortunately conditions favorable to the use of this method are rare, but it is used at several stations, notably at Raquette River at Piercefield, N. Y. (see p. 39 and fig. 12), and at St. Mary River near Babb, Mont. (p. 38 and fig. 11). Considerable ice is present at both stations, but as a rule the control section remains clear throughout the winter.

In using this method the engineer should closely inspect the gageheight records and compare them with temperature records to detect the presence of backwater. If discharge measurements made in several winters have shown that ice rarely occurs at the control section and that the regular open-water curve is applicable fewer measurements are needed with this method than with any other. An opencontrol section, however, with ice above, implies as a rule that the control section is at rapids at which anchor ice is likely to form. In order to detect the presence of anchor ice during extremely cold periods the gage should be read twice a day. Readings higher in the morning than in the afternoon indicate the presence of anchor ice, and care must be taken to read the gage soon after the point of maximum daily temperature, when the control section is likely to be clear.

\section{SECOND METHOD.}

The conditions favorable to the use of the second method-in which observed gage heights are applied directly to a special rating curve based on winter discharge measurements and gage heights to the water surface-are most likely to be found on the larger rivers, where the slope and cross section may be fairly uniform for long stretches. In general, however, this method should be used with great care and the period of applicability of the curve should be

${ }^{2}$ Determination of stream flow during the frozen season: Eng. News, vol. 65, p. 126, February 2, 1911.

$17020^{\circ}-$ wsP $337-13-4$ 


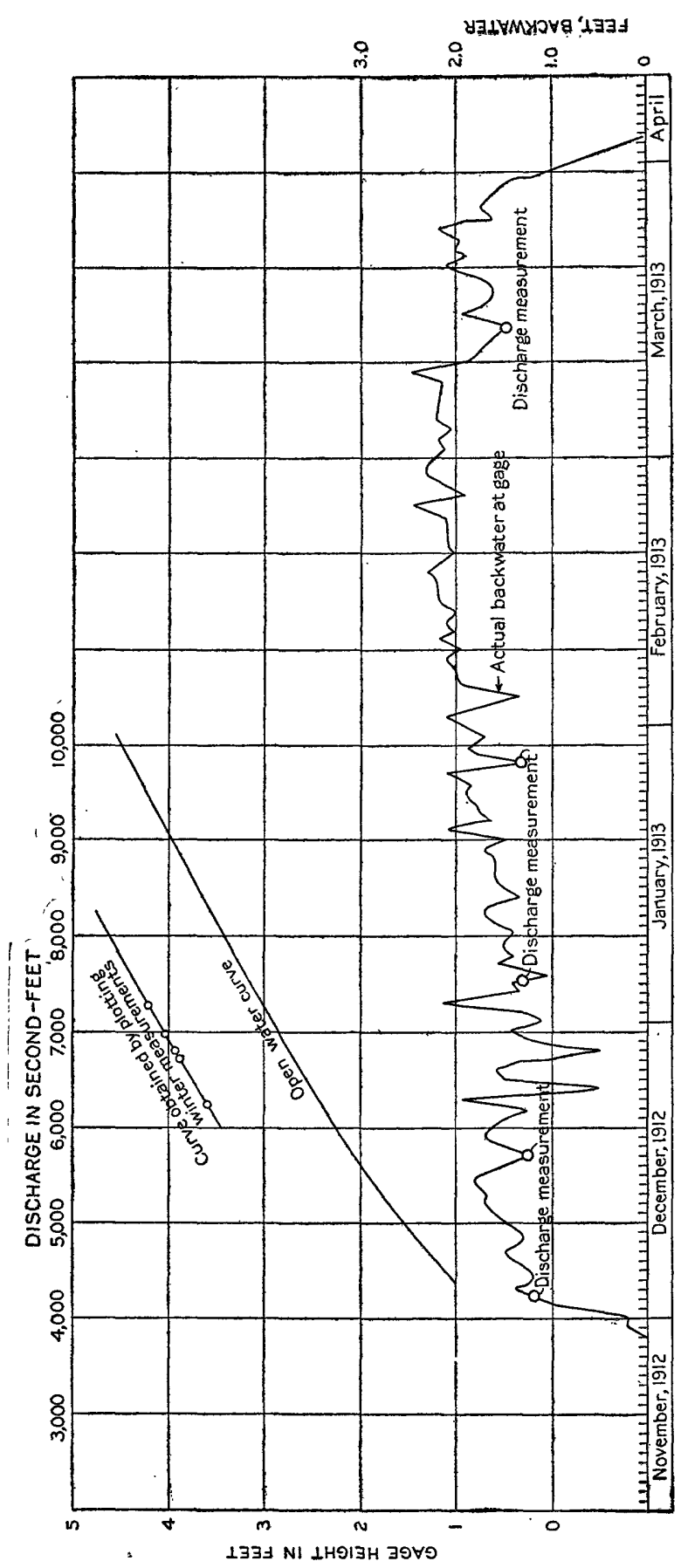

closely determined

by discharge measurements. Furthermore, its a selection implies that the effect of si backwater from the ice is con-

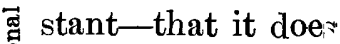
not vary either with variation in the length of the period througl which the curve is applicable (that is, with time) or with variation in temperature. As the time and temperature are two factors directl'y connected with the formation of tha ice and therefor? of the backwater, it would seem that they should be considered in any method for determining discharga when ice is present. On a large stream that freezes $\mathrm{un}$ if orm ly and that varies little in flow all discharge measurements made when the ice has reached its permanent cor dition may plot on a curve, but it is evident that this curve will not correctly represent the relation of stage to discharge in the period of transition from open water to solid ice, and vice verse. 
It will also not represent conditions if between the times of measurement the character of the ice cover has changed greatly as a result of changes in temperature.

If backwater is caused by a combination of anchor and surface ice, discharge measurements made at certain times might give a smooth curve that would in reality not apply except on the days of measurement. An illustration is furnished by observations on Rainy River at International Falls (fig. 15). It is assumed that measurements were made on December 2, 17, January 5, 17, and March 14 .

The diagram gives the actual backwater curve; the points plotted on the ice curves are deduced from the plotted points showing the actual discharge and backwater on the days when the measurements were made. It appears, therefore, that even a smooth curve derived from measurements may be deceptive, and that the continued use of such a curve as that shown on the diagram would lead to large errors.

This method should be used only when many discharge measurements have been found to plot on a smooth curve and when conditions of temperature and ice are stable for long periods. See, for example, the open-water curves and plotted ice measurements of Red River at Grand Forks, N. Dak. (Pl. III, p. 38), Elk River near Big Lake, Minn. (fig. 9, p. 35), and Crow Wing River at Pillager, Minn. (fig. 10, p. 37), which exhibit lack of relation between the measurements made from year to year.

\section{THIRD METHOD.}

\section{EYE METHOD.}

The method most commonly employed at the present time to determine the flow of streams either partly or completely covered with ice is that which utilizes the discharge measurements and data regarding climatic conditions and the occurrence of ice in connection with observed gage heights by means of eye-inspection of records of temperature, precipitation, and gage heights, estimating the daily discharge for the period between times of measurement, and adjusting the determinations by comparing with results obtained at near-by stations. The monthly mean of such determinations is also compared with monthly means at adjacent stations in order that any large error may be detected.

The accuracy of this method depends largely on the uniformity of stream flow between times of measurements, the number of measurements, and the engineer's knowledge of general conditions. Care must be taken that the discharge, as estimated, is not greater than would be given by the application of gage heights to the open-water rating curve. In general this method should give more accurate results than method No. 2 , because it considers the time and temperature factors. 
The method will give good results at stations in localities where temperatures are fairly constant over long periods of time and where the flow is affected by surface rather than by anchor ice. Under su.h conditions fewer measurements and gage readings are required than at stations situated where climatic conditions are irregular. Temperature records from the nearest Weather Bureau station are generally sufficient.

The disadvantage of this method is that it is impossible to chesk its results, as no record is left of steps employed.

\section{GRAPHIC METHOD.}

The method that gives the best results, taking into consideration as it does all conditions tending to destroy the open-water relation between stage and discharge, and that can be used at all stations whose control section is modified by ice, is the graphic method. In applying it the records of temperature, precipitation, and watersurface gage heights are plotted on cross-section paper, and the $\mathrm{ccm}^{\mathrm{m}}$ rection that must be applied to the daily gage heights to insure the applicability of the open-water curve is determined, the variation in this correction between times of measurements being estimated by comparing the variations in gage height with those of temperaturo, precipitation, and ice. This method has the obvious advantage of enabling the engineer to compare directly the variation of discharre with temperature which has been shown to be the great factor in affecting winter stream flow. The method was first suggested by the author about a year ago. ${ }^{1}$ Later studies have resulted in minor changes in the mode of procedure but have confirmed the opinion that the method will give, especially for stations at which the flow is affected by anchor ice or a combination of anchor and surface ice, fairly accurate determination of the effective gage height.

The use of the method is illustrated by the studies of Rainy River at International Falls, Minn., at a gaging station just below the plant of the Minnesota \& Ontario Power Co. The flow at the plant is d?termined by the Canadian department of public works by means of wheel ratings; the flow at the gaging station is computed by tl? engineers of the United States Geological Survey from current-meter measurements. The mean monthly discharge, as determined indapendently by the two methods during times when there is no backwater at the Survey gage, is well within 5 per cent of the true mean. Although the slope between the dam and a point some miles below the gage is small, ice rarely forms on the river, apparently because

1 The graphic method of determining stream flow was proposed by the author at a conference of district engineers of the water-resources branch held in Washington, January, 1913, when the relation between temperature, backwater, and stream flow was first shovrn graphically. A brief outline of the method was published in Eng. News, vol. 69, cn. 725-727, A pr. 10, 1913. 


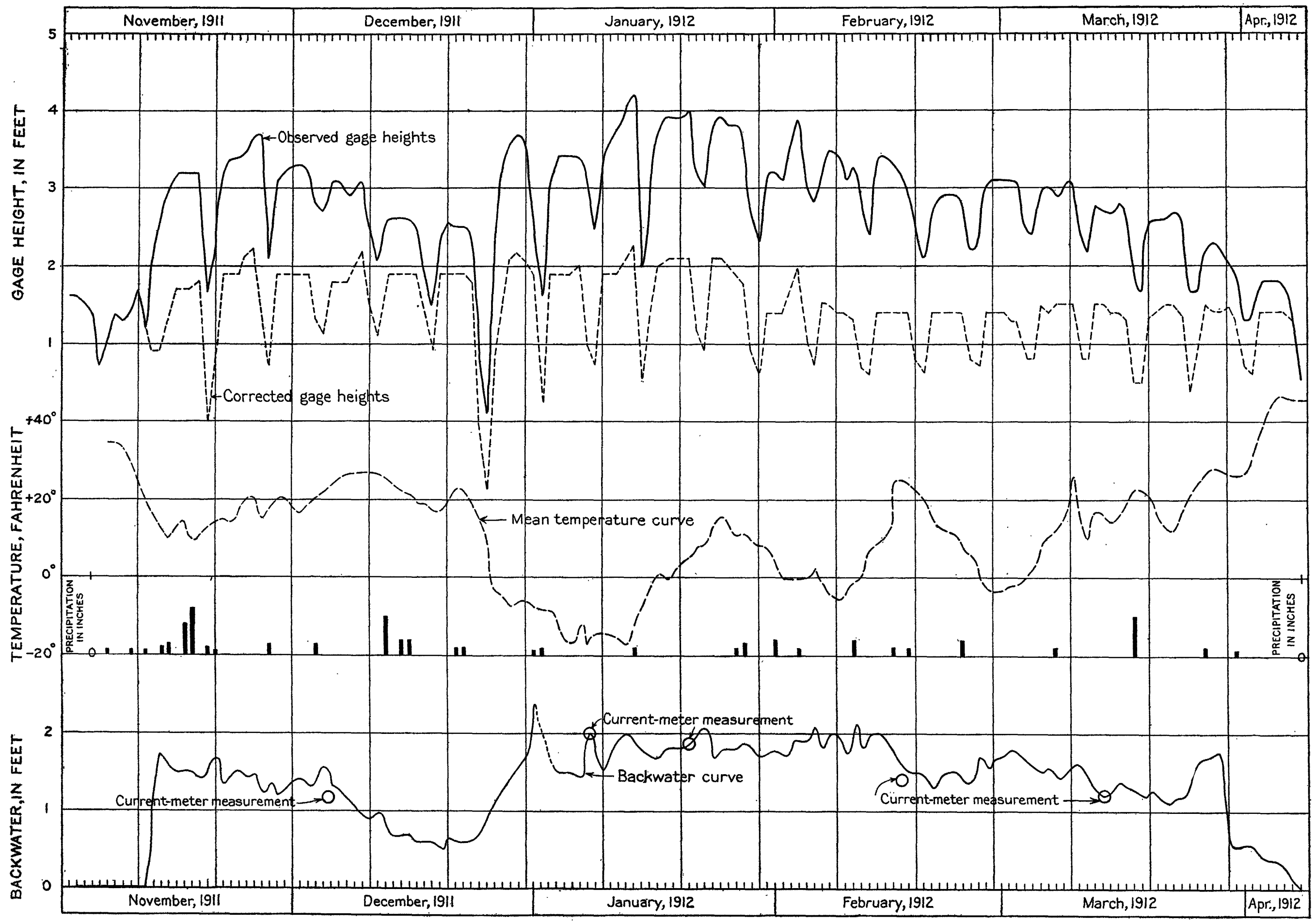

DIAGRAM SHOWING RELATION BETWEen Gage HEIGHTS, BACKWATER, AND TEMPERATURE: RAINY RIVER AT INTERNATIONAL FALLS, MINN. 
the water coming from ice-covered Rainy Lake (having an area of over 300 square miles) is at a temperature high enough to prevent the formation of ice for a considerable distance, even though the mean temperature for six months is below freezing. The mean temverature (in degrees Fahrenheit) for November is $23^{\circ}$, for December $\therefore .7^{\circ}$, for January $5.4^{\circ}$, for February $5.7^{\circ}$, and for March $18.9^{\circ}$. As the temperature of the water slowly changes after leaving the lake, surface ice forms along the edges of the river, and at Manitou Rapids, about 31 miles below the gage, there is probably a combination of anchor and surface ice. Having the actual daily discharge as determined by the water-wheel ratings, the gage heights at the Survey gage, and a well-defined rating curve for that gage, it has been possible to determine the actual backwater daily throughout the winter. The relation between the backwater and the mean temperature, as diagrammatically shown in Plate VI, is fairly well defined. The daily effect at the station of anchor ice at Manitou Rapids is dininished by the pondage in the river between the gage and the rapids. The average slope of the river between the gage and the rapids is approximately 0.22 foot per mile, and the amount of backwater ranges from zero to more than 2 feet. On Plate VI the backwater curve has been drawn separately from the gage height curve in order to show the relation between them. In practice it has been found that this extra step is not necessary and possibly is not advisable, as on an uncontrolled stream it is possible to vary the curve of effective gage height with the mean temperature. This method follows somewhat the Stout method ${ }^{1}$ of determining the flow in shifting channels in using a single rating curve and correcting the sbserved gage heights to apply to the curve. In the Stout method the correction is based almost entirely on discharge measurements; in this ice method time and temperature are factors, as weil as disharge measurements.

The application of the method to the determination of flow of a stream completely covered with ice is illustrated in figure 16 . In this diagram the line of effective gage height has been corrected somewhat to conform to the temperature.

The diagrams forming Plate IV (p. 46) illustrate the use of this nethod to determine the flow of the Kootenai at Libby, Mont., whare tage is affected by both anchor and surface ice. The plate shows that anchor ice leaves the river with rise in temperature and exhibits also the close relation between temperature and effective gage height.

In order to develop this method and to determine the effect of the different varieties of ice on backwater and the relation between temverature and stream flow, it is essential that detailed stream gaging

${ }^{1}$ Hoyt, J. C., and Grover, N. C., River discharge, pp. 103-104, 106-107, John Wiley \& 'ons, New York. 


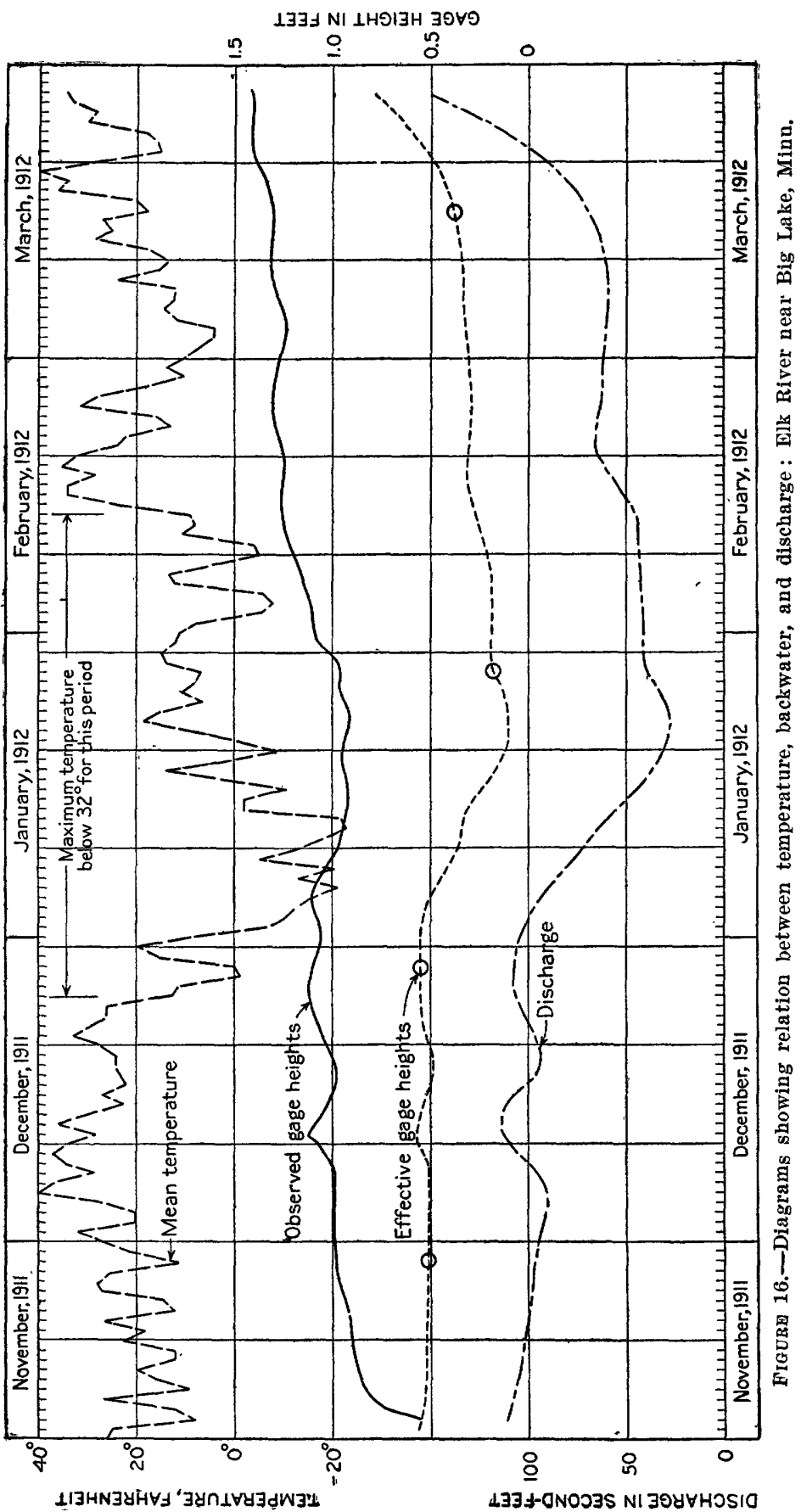


be carried on throughout the winter and that studies be made of maximum and minimum temperature, gage height, and discharge at stations at which stage is affected by ice.

\section{APPLICATION OF GRAPHIC METHOD.}

Many streams in the northern and western States are not completely covered with ice throughout the winter months. At many places the ice on a stream may extend but a short distance from the banks, leaving an open channel in the center; at others the current may be so swift that the channel remains entirely open throughout the winter. Such conditions are common in hilly or mountainous regions, where stream gradients change rapidly, and may exist in the vicinity of gaging stations to such an extent as to make it impossible to estimate discharge by methods that are applied to streams that are completely ice covered. For example, the channel may be open at the gage or at the control below, but the stage may be materially affected by the presence of anchor ice; or, if complete ice cover exists below the natural control section, ice jams may form, creating a temporary ice control which produces backwater at the gage. If the stream is frozen along the banks at the gage and at the control below, but is open in the center, the gage readings are affected by ice jams at the control and by changes in the conditions along the banks.

If a stream is deep and sluggish and under complete ice cover for a considerable distance above a gage located at a riffle, the gage readings may not be affected by ice because the water coming from beneath the ice is at a temperature sufficiently high to prevent the formation of ice at the control section.

The extent of these effects depends on the natural condition of the channel and on the general condition of the ice, the latter depending largely on temperature. Each station where such conditions exist, singly or in combination, presents a problem that can be solved only after a careful study of all the factors.

At a station located in a comparatively sluggish stretch of a stream where the channel is partly open throughout the winter and the control is a riffle the gage heights will be materially affected by anchor ice, which will form at temperatures of zero and below. The amount of anchor ice will depend on the roughness of the channel and the velocity of the current and will tend to increase as the temperature falls and decrease as the temperature rises, disappearing entirely as the temperature approaches $32^{\circ}$. As the variation in daily temperature may have an important effect on the amount of anchor ice formed, and therefore on the fluctuations in stage at the station, a record of the maximum and minimum temperatures is necessary to arrive at a proper interpretation of variation in the gage heights 
caused by anchor ice. It is also necessary to have a more complete record of the gage heights at stations of this character than at stations where complete ice cover is formed. At least two readings should be made each day as nearly as possible at the time of maximum and minimum temperatures. Careful observations should be made to determine the maximum temperature at which anchor ice forms and at which it may be expected to disappear, and the relation between the increase of the anchor ice and the decrease in temperature. On days when the temperature rises above this maximum, if other conditions are normal, it may be assumed that no anchor ice exists and that the gage heights at or immediately following the time of maximum temperature are reliable. With this information available it is possible to determine the corrections to be made to the gage heights in order that they may be applied to the open-channel rating curve. As a check on the gage corrections a number of discharge measurements should, if possible, be made at different temperatures.

On a stream with small slope the formation of anchor ice may create a reservoir in which a considerable part of the flow may for a time be stored. Discharge measurements made during that time will indicate a flow less than the natural flow of the river; but measurements made while the anchor ice is going out, or after it has gone out and before the river has returned to its normal stage, will indicate a flow greater than the normal flow of the river, because of the release of the water that had been held in storage by the anchor ice. It is doubtful whether any corrections can be determined and applied to discharge measurements made under such conditions, which will recur whenever anchor ice forms at the gaging station or at points above. The measurements should if possible be made when the stage is normal.

The relation between the temperature, gage heights, and discharge can be best studied by plotting the data on cross-section paper, using the horizontal ordinate for the time and the vertical ordinate for temperature, gage heights, and discharge. Care must be exercised in applying this method of correcting gage heights, especially when there is a great and sudden change in temperature which may change the general conditions at the station.

The effect of shore ice must also be considered. A large range in temperature doubtless affects the conditions along the banks of a stream, but to a less extent than it affects anchor ice in the open channel.

When the maximum temperature is at or above that at which it forms, anchor ice will rise to the surface and float away. If other conditions are normal, gage heights observed after the anchor ice has disappeared will be an index of the discharge and will represent the minimum gage heights for the day. By plotting the tempera- 
ture and gage heights on cross-section paper and sketching in a curve following the minimum gage heights, when they occur at a temperature above that at which anchor ice forms, an estimate can be made of the effect of anchor ice on gage heights during the intervening days.

If there is in the vicinity of the station a section in which the current is swift and the channel remains open all winter, a gage should be installed, as at many stations gage readings in open sections with high velocity will indicate the discharge during periods of extreme low temperature in which the regular gage will be affected by ice. The flow at such stations should be computed from the observations at the temporary gage, but the station gage should be read regularlv to obtain a record for comparison.

Whenever possible stations for winter records should be established at the outlets of lakes or in the vicinity of large springs. The water at such places is usually at a relatively high temperature, and if rapids are present a site can usually be found at which the channel remains open throughout the winter, even during periods of extremely low temperature.

\section{FIELD METHODS.}

\section{SELECTION OF STATIONS.}

The location and number of stations at which winter records will be maintained, as determined in connection with the work of the water-resources branch of the Geological Survey, depend on conditions that vary considerably in different districts, but the most important condition is common to all districts and is the amount of money available. The lack of winter records has not been entirely due to the difficulty in obtaining them, but rather to the fact that underestimation of their importance has led to an unequal distribution of funds. Comparison of the number of stations that have been discontinued on account of ice with the number that are maintained throughout the year shows that the greater part of the available funds has been expended on open-water records. As records of winter discharge are of great importance, funds should be so allotted that certain stations can be maintained throughout the entire year, even though the adoption of such a course may necessitate the abandonment of some stations at which open-water records have heretofore been collected. Other factors determining to some extent the number of stations to be maintained are (1) distribution of stations in the drainage basin, (2) action of ice at the control section, and (3) ease of operation.

The almost entire lack of close uniformity or agreement in the open-season flow of any two streams has been proved by many observations. Consideration of the factors that influence the winter 
run-off-factors as varied and probably as influential as those affecting open-water flow-shows that the flow at different stations is comparable only within a very small area, and even in such areas conditions may vary so widely that estimates of flow derived by comparing records would be subject to large errors. If comparison of the records at stations located in close proximity on a stream shows close agreement in the open-water flow, a close agreement in winter flow is probable, but it is doubtful if the comparative method should ever be used to estimate the flow of streams in adjacent drainage basins. At least one station for winter records should therefore be maintained at or near a regular open-water station in each main river basin or subdivision.

The station selected for maintenance should, if choice is possible, be that whose control section is least affected by ice. If previous studies have shown that the control section is, as a rule, entirely free from ice, the station can be carried on in the same manner as an open-water station. The study of the station records known to be unaffected by ice will help greatly in determining the flow at stations at which ice is present, and the greater the number and distribution of such stations the greater will be the accuracy of the winter records throughout the entire district. Only occasionally can the records be used directly to estimate the flow at other stations, but they may serve to detect changes in uniformity of flow, and, if climatologic data are available, to determine the relative discharge.

The ease with which a gaging station may be operated will depend not only on the amount of ice present and the fluctuations in stage, but also on its proximity to headquarters. Stations maintained in groups or circuits are more economically conducted and in general will give more accurate records than isolated stations, as tendencies of flow can be closely compared. The ice on an uncontrolled stream will probably seldom be in such condition that measurements can not be made. On a stream controlled by power plants the ice may form layers with water between or standing on the surface, and measurements may be impossible. As a rule stations should not be maintained at localities where diurnal fluctuations in quantity of discharge occur in combination with fluctuations in stage caused by ice. It is doubtful if even a recording gage would afford a reliable basis for estimates of flow under such conditions; if the wheels can not be rated and records must be obtained, notes should be made regarding the daily operation of the plant.

The number of stations that will be carried through the year will depend to some extent on the number of stations maintained in cooperation with 'States, commissions, or private parties. As a rule, stations located at power plants or maintained largely by private 
cooperation should, if possible, be operated throughout the year, especially if conditions are such that they afford fairly accurate records.

\section{POWER-PLANT RECORDS.}

At modern power plants large enough to utilize the mean annual run-off of a stream the greater part of the water during the winter passes through the wheels and very little escapes over the spillway. The necessity for determining the flow over spillways, flashboards, and through sluices is thus avoided, and one of the larger sources of errors is eliminated from estimates of the daily and monthly flow based on power-house records. The records of flow computed at most modern plants are nearly always available for use, and their accuracy can, as a rule, be checked. At plants so operated that all the water passes through the wheels, the wheels can be rated and the discharge can be estimated from records of gate openings and head. Records from power plants in any part of a drainage basin may assist greatly in the discovery of tendencies of flow at gaging stations within that basin.

At regular gaging stations located at dams care must be taken to. make allowance for the effect of apparent increase of head caused by ice on the crest. If the ice forms only in the pond and the crest is clear, the effect of backwater at the gage will be inappreciable.

Power plants that include storage systems will, in general, be so operated that the reservoirs will be filled to maximum capacity at the beginning of the period of ice and will be empty at the end. The records of water released from such reservoirs, either in terms of rate of flow or in terms of volume, are exceptionally valuable if gaging stations are located below them, as the measured flow can be corrected from the storage flow and the revised figures showing natural discharge can be compared with records of discharge at other stations.

\section{GAGES.}

The presence of ice at the control section has heretofore had little consideration in determining the location of gaging stations. In collecting winter records at a station already established it will be necessary therefore either to use the gage as installed and make allowances for the effect of ice or to install a supplementary gage to be used during the winter months. In establishing new stations and installing auxiliary gages care should be taken to select sites with control sections as free from ice as possible throughout the winter. As the availability of an observer has determined the location of many of the gages, it may not be possible to find better sites than those now in use. On some rivers, however, it may be desirable to relocate the gages in stretches free from ice and to develop a new winter rating curve, either by comparison of the records with open- 
season records of discharge or by current-meter measurements. In sections of the country similar to Minnesota, where winter temperatures are low and stream gradients are small, many of the rivers have no open sections and the use of the present equipment must be continued.

Of the three types of gages-chain, staff, and recording-the chain gage is probably the most easily maintained during the wintêr. Staff gages, both vertical and inclined, unless extremely well fastened and protected, are likely to be changed in datum or wrenched loose from their supports by the pressure or motion of the ice. On wooden gages the numbers are effaced, making it necessary to install new gages each spring. An inclined gage is difficult to read, as the ice pushes up over it and must be chopped with a chisel, the use of which may injure the gage itself. The same statement applies, although less forcibly, to the vertical staff gage. Vertical gages fastened to piers in the center of the river may at times-during ice-forming periods and thaws-be dangerously inaccessible to the observer.

Recording gages are serviceable for winter records only when intakes and wells are so constructed and protected that they will not freeze. The effect of freezing in the well can be reduced to some extent by the addition of oil, by burning an oil lamp, or by installing an electric light with the bulb near the surface of the water.

A chain gage can as a rule be maintained as satisfactorily and with as little care during the winter as during the summer. Its datum, especially when the gage is attached to a bridge, is no more likely to change in winter than in summer, its scale board is not subject to injury by ice, and thin ice can be broken by dropping the weight. If a recording gage is not used, the observer will lessen his labor by covering the gage hole with brush, which will to some extent prevent freezing.

The number of gage readings required will depend largely on the character of the ice at the station and the regularity of flow of the stream and, like the type of gage, must be determined experimentally. On ice-covered streams whose flow is uncontrolled by storage and is regulated largely by temperature, gage-height observations varying from three a week to one a day should be sufficient.

The determination of flow of streams solidly covered with ice and controlled by storage presents difficulties that can hardly be overcome with any number of gage readings, although possibly better results will be obtained with a recording gage than with any other type. If fluctuations in stage at any station are caused principally by anchor ice, the gage, if not of the recording type, should be read at least twice a day-once in the morning and once shortly after 
the period of highest temperature. On an uncontrolled stream whose winter flow is affected by anchor ice alone the lowest of two readings a day will probably give nearly as good results as the record of an automatic gage.

The engineers of the Geological Survey consider the use of a recording gage undesirable at stations where much ice forms, but favor its use at stations where the effect of ice is small and the flow is controlled. For certain stations at which the stage is affected by anchor ice, as, for example, on Kootenai River, near Libby, Mont. (see $\mathrm{Pl}$. IV, p. 46), the use of a recording gage is advisable. At recording gage stations on streams that vary slightly in flow economy may be gained by discontinuing the automatic gage record during the winter and depending on twice-daily gage readings. On streams in the Great Basin, which show sudden fluctuations caused by changes in temperature, recording gages are advisable even though they are not in operation during periods of low temperature. As the degree of accuracy of winter gage heights need not be greater than the accuracy with which the effective gage height can be determined, the necessity for recording gages during the winter is doubtful.

\section{CLIMATOLOGIC RECORDS.}

The climatologic data necessary for a proper interpretation of records of winter stream flow consist in general of records of temperature and precipitation. At many places, and especially when only surface ice is present, the records of the Weather Bureau may answer all requirements if arrangements can be made for receiving them, but as a rule each winter station should be equipped with a reliable thermometer, and the temperature should be recorded on the cards in connection with the gage heights. The required outlay is small and will be more than compensated by the value of the records in making computations and the interest added to the work of the observer. Readings taken early in the morning and about noon will give data from which the mean temperature can be closely determined and fix the limits at which anchor ice forms and disappears.

The effect of precipitation on daily run-off during the winter is less than that of temperature, and the records are not so important in the computations. The weekly "ice bulletin" of the United States Weather Bureau probably furnishes all necessary data regarding snowfall, so that the gage reader need report only the occurrence of rain.

When anchor ice or frazil is present notes regarding the clearness of the sky-an important factor in their formation-may also be of value. 


\section{DISCHARGE MEASUREMENTS.}

\section{DETERMINATION OF SECTION.}

If the regular section at a gaging station is open or only partly frozen, it may be used for winter measurements by working from the ordinary equipment over the open part and from the ice on the same section along the edges where ice cover may have formed. When the streams are entirely frozen and measurements have to be made through the ice a knowledge of the character of the section during open water is essential.

At stations on streams that freeze each year sections for making winter measurements should be selected during the open season and so marked in some way, either by posts or by distances from some permanent objects, that their position can be readily determined after the stream is frozen. These sections should have the same general characteristics as good open-water sections; that is, depth and velocity should be fairly uniform, the bottom should be smooth, and there should be no cross currents. The previous selection of the section insures more accurate determination of the flow under the ice than would otherwise be possible, as the character of the flow beneath the ice will be nearly the same as in the open section. If the approximate cross section of the stream is known, the holes can be so spaced that the amount of water measured at each point will be in proportion to the total discharge, as in open-water measurements. A knowledge of the cross section may also save labor in cutting holes to determine the position of the edge of the water.

If the presence of frazil or of floating anchor ice at a section affects more than about 10 per cent of the total cross section, the measurements should, if possible, be made at another section where such conditions do not exist; for example, at rapids, where velocities are high enough to carry away the ice quickly. Although such sections may not be so desirable, in view of the depth and distribution of velocity, as the regular sections, the measurement will probably be more accurate than that obtained in a section which is partly clogged with frazil.

When the section for winter measurements has not been selected previous to the formation of ice cover and the engineer has no knowledge of conditions the measurement should be made at the regular open-water section, if it is equipped with a cable. If the open-water section is at a bridge, however, it is generally wiser to go upstream, in order to avoid the disturbing influence of the piers on the current. Ordinarily the ice in the open will also be safer than that under a bridge, and safety of the ice should be one of the first conditions investigated in making winter measurements. 


\section{INSTRUMENTS.}

The instruments necessary in making winter discharge measurements are a current meter, weight, cable, telephone attachment, and regular equipment; standard rods, 5 to 7 feet long, an ice chisel, and an ice measuring stick.

The meter and all its connections should be carefully examined to see that they are in good working order before the instruments are taken to the section to be measured. The meter itself should be lubricated with oil of the best grade, but sparingly, for if large quantities of oil are used it is likely to congeal and increase the friction of the meter.

Where the depths are so great that rods can not be used, the regular cable attached to the stem of the meter can be more easily handled than the smaller wire generally used for that part of the cable that goes into the water. Markers on the meter cable, 1 foot apart, measuring from the center of the meter, will be convenient in measuring the depth of the water and in placing the meter. Where depths under the ice are 5 feet or less, a rod to the end of which the meter is fastened will be most satisfactory. For depths over 5 feet rods made in 3 or 5 foot sections may be employed, as a rod made up of more than 5 standard 1 -foot sections is too flexible. Rods on which the meter can be placed at the required depth, and which are constructed with the foot piece to rest on the ground, are not suitable for use when the temperature is below $32^{\circ}$, as the meter may freeze during the time required to set it; and if it could be kept from freezing, the operation would be difficult, as the meter rod is likely to coat with ice. Either a meter should be used with the rod fastened to the yoke or the regulation old-style meter with the end of the rod in the slot.

For the recording device one wire may be used, the rod being employed for the second connection; but two wires, one running from the meter and the other fastened to the lower section of the rod and connected to a standard plug will generally be more satisfactory, as ice that forms in the joints of the rod seems to cause resistance to the electric current. The twisted wire can be carried up alongside the meter rod and secured at frequent intervals with tire tape. When the measurement is completed this wire can be wound around the lower section of the rod, to which one end of it is already fastened.

Another method ${ }^{1}$ is to run a wire down inside the rods. The ordinary meter cable serves very well. Then two holes are bored near the bottom of the lower section and the two strands of cable brought out through these. One strand is permanently connected

1 Successfully used by the engineers of the United States Geological Survey working in the Montana district. 
with the rod, and a standard connecting plug is attached to the upper end of the cable, so that in setting up the meter only one connection is necessary. In taking down the rod the sections are unscrewed and slipped along on the cable, leaving sufficient space between, so that they may be folded up into a bundle no larger than one section.

A useful article that may be packed in the meter box is a Marble safety ax, with either a wooden or steel handle. With this implement sufficient wood can be cut to supply a small fire by which, if necessary, the meter may be thawed.

A satisfactory ice chisel ${ }^{1}{ }^{1}$ is illustrated in Plate VII, $A$. The blade of this chisel is narrow and is not notched, and it is made of rather soft steel so that it can be easily sharpened with the hand file that should form part of the equipment. The handle is solid steel, and the complete chisel weighs about 14 pounds. A chisel lighter than this is of little value, as its jar when the ice is struck tires the hands very quickly.

A number of ice augers for cutting holes in the ice are on the market, but unless a large number of measurements are to be made at a station their size precludes their use in general routine work. The United States Army engineers, whose measurements are made almost daily at one location, often use an auger rather than an ice chisel.

The measuring stick shown in Plate VII, $A$, is made of 1-inch by 1 -inch material to one end of which a 3 -inch angle is fastened. The sticy is graduated in feet and tenths by means of double pointed tacks, the zero being at the angle iron.

\section{METHODS.}

Winter measurements made from a cable or bridge in a section without ice cover are made in the same manner as open-water measurements, except that the meter should not be taken from the water unless absolutely necessary until the measurement is completed. The soundings can be taken by lowering the weight until it touches the bottom and then raising it until the head of the meter is just under the surface of the water, adding to this depth the distance from the top of the meter to the bottom of the weight. If it is necessary to remove the meter temporarily from the water, on its return it should be permitted to run for a period before the revolutions are recorded, as the warmer river water will tend to thaw out any slight congealing in the meter. If the meter is out of the water until it becomes practically rigid it should be thawed and thoroughly dried near a fire, care being taken that it does not become so hot as to melt the rubber connections or the solder on the cups.

1 This chisel is made by Gifford Wood Co. and, except for the jointed handle, is a regular stock pattern. 


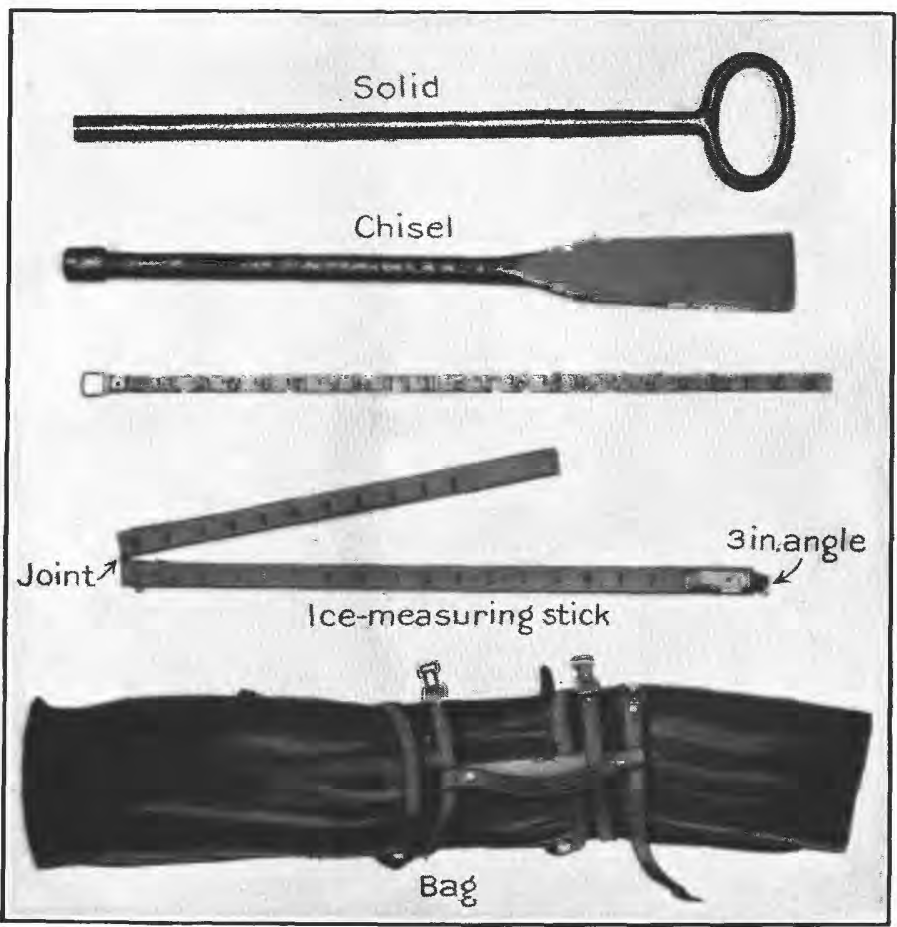

A. ICE CHISEL, ICE MEASURING STICK, AND BAG.

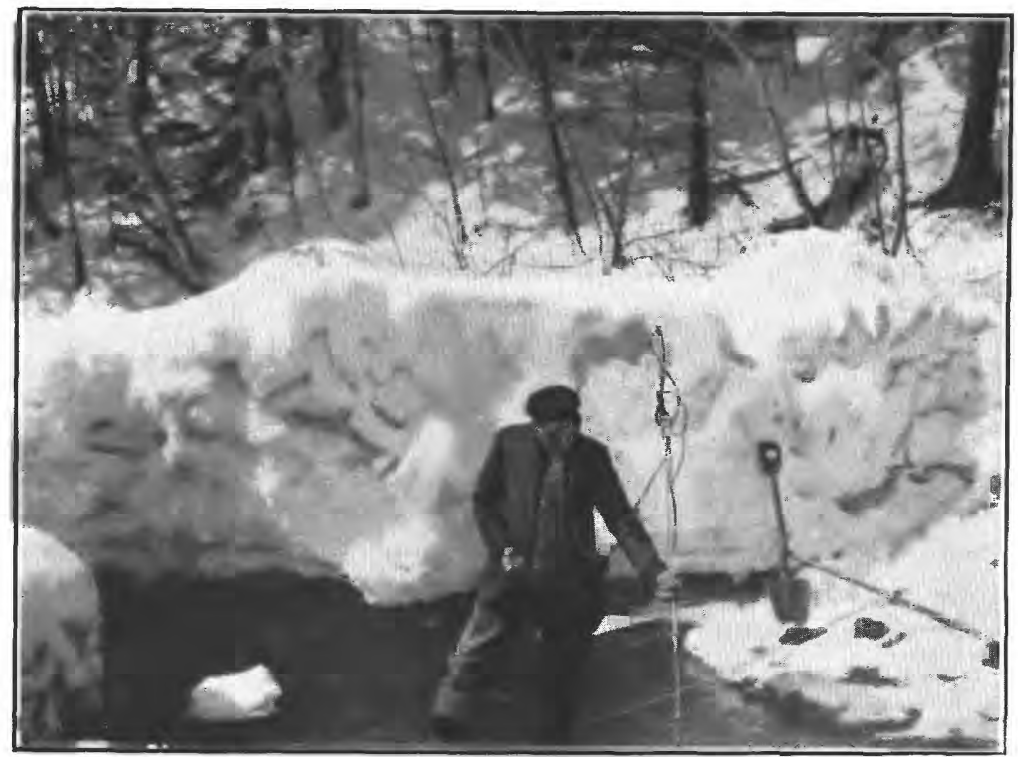

B. WINTER MEASUREMENT ON SHOAL POND BROOK, NEW HAMPSHIRE. 

The first operation in measurements under ice cover is the cutting of the holes through the ice. The holes should be spaced 5 to 10 feet apart, the interval depending on the width of the stream. (See Pl. I, $A$ and $B$, p. 10 ; Pl. II, $A$ and $B$, p. 20 ; and PI. VII, $B$, p. 64.) On small streams, where measurements of velocities are desired at many points close together, an entire section may be cut out, thus preventing the greater part of the vertical pulsations of the water. The position of the holes need not be accurately determined before cutting; they should, however, be placed in a straight line and as near as possible at right angles with the current. Round or oblong holes are easier to cut than square holes, and the larger diameter should be parallel to the current. They should be large enough to permit the meter to be easily raised and lowered. A shovel will be found almost essential in clearing away snow from the ice in the vicinity of the holes and removing the chopped ice from the holes. The first 3 or 4 inches of the ice can be cut more quickly with a sharp ax than with the ice chisel, but with the chisel illustrated (PI. VII, A) an ax is not necessary. The ice should be cut only at the circumference of the circle, as large cakes can be taken out with less shoveling than the small ones that are made when the entire cross section of the hole is chopped. Care should also be taken not to cut through the ice into the water until a few rapid blows of the chisel will clear the entire section. By working carefully holes can be chopped through ice 1 to 3 feet thick with very little splash; if, however, water is standing or flowing on the ice to depths of 1 or 2 inches it is almost impossible to chop holes without getting wet.

Where depths under the ice are greater than 4 or 5 feet a small cord should be tied to the ice chisel to prevent it from slipping into the water if it penetrates the ice unexpectedly.

As a rule it is advisable to chop one hole through the ice in the center of the section in order to detect the presence of frazil or floating anchor ice. If the hole so cut can not be kept clear from the finer particles of frazil, the measurement will probably give inaccurate results, and the engineer should endeavor to find a better section.

When the holes are cut and cleared of the chopped ice the distances between them should be measured with a steel tape and recorded in: the' notebook, leaving sufficient space between the recorded measurements for the record of velocities in the vertical. As the winter flow is likely to be fairly uniform, the soundings may be taken independently from the measurements of velocity. The gage height to the water surface should then be read and the soundings taken either with the rod or with the weight and cable. At each hole should be recorded (a) the thickness of the ice, (b) the distance from under surface of ice to water surface, and (c) the total depth of the 
water. From these data can be computed the depth at which the meter must be placed in each hole in order that it may be at the $0.2,0.8$, or 0.5 position beneath the ice. Thus-

$$
\begin{aligned}
& 0.2 \text { depth }=(c-b) \times 0.2+b \\
& 0.5 \text { depth }=(c-b) \times 0.5+b \\
& 0.8 \text { depth }=(c-b) \times 0.8+b
\end{aligned}
$$

The notation and a form for recording the data are illustrated in figure 17.

The information collected regarding the total thickness of the ice need not enter into the measurement.

When holes are cut through the ice a vertical pulsation, which may

\begin{tabular}{|c|c|c|c|c|c|}
\hline \multicolumn{6}{|c|}{ OBSERVATIONS } \\
\hline \multirow{2}{*}{\begin{tabular}{|c|} 
Distance \\
from \\
initial \\
point
\end{tabular}} & \begin{tabular}{|c|} 
Thickness \\
of ice
\end{tabular} & $\begin{array}{l}\text { Total depth } \\
\text { of water }\end{array}$ & \multirow{2}{*}{$\begin{array}{l}\text { Depth of } \\
\text { meter from } \\
\text { water surface }\end{array}$} & \multirow{2}{*}{$\begin{array}{l}\text { Time } \\
\text { in } \\
\text { seconds }\end{array}$} & \multirow{2}{*}{ Revolutions } \\
\hline & \begin{tabular}{|l} 
Water surfacce \\
to \\
boto of
\end{tabular} & $\begin{array}{c}\text { Effective } \\
\text { waterdepth }\end{array}$ & & & \\
\hline \multicolumn{6}{|l|}{0} \\
\hline \multirow[t]{3}{*}{10} & $a$ & $c$ & $(c-b) \times .2+b$ & & \\
\hline & 3 & $c-b$ & $(c-b) \times 5+b$ & & \\
\hline & & & $(c-b) \times .8+b$ & & \\
\hline \multicolumn{6}{|l|}{15} \\
\hline & & & & & \\
\hline & & & & & \\
\hline
\end{tabular}
amount to nearly half a foot, is often noticed in the water. In measur-

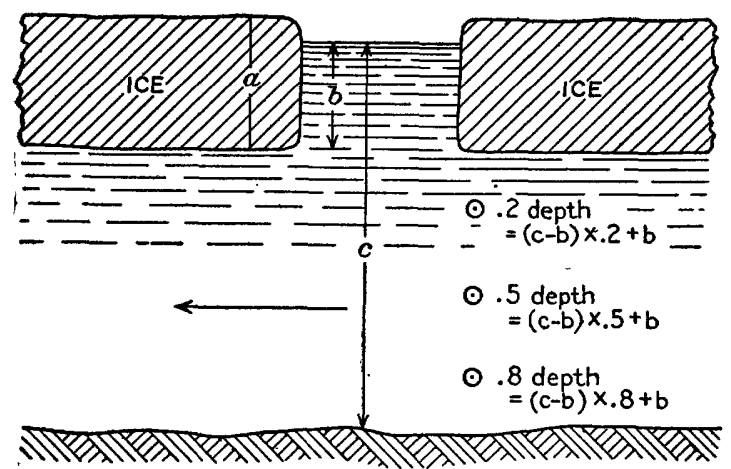
charge measurements and new form proposed.

oughly made before it is placed in the water. The gage heights to the water surface should then be read again and the measurement begun.

The meter should be so held in the hole that the head is as far upstream as possible to avoid the effect of the vertical pulsations. water care should be taken to determine the mean. If the depths beneath the ice are greater than 2.5 feet, the measurement should be made by the 0.2 and 0.8 point method; for depths between 1.5 feet and 2.5 feet velocities should be observed at 0.2 and 0.8 and 0.5 depth; for depths less than about 1.5 feet the mid-depth method shouild be used.

When the depth at which the meter must be held in each hole to record the mean velocity has been computed the meter can be assembled, care being exercised that all connections are thor-

ing the depth of the 
If a rod is used, the meter can be kept in position by holding the rod against the upstream side of the hole; if a cable, the meter can be held at one position more easily by standing on the cable than by holding it in the hand. The number of revolutions and the time are recorded as in open-water measurements. After the complete data for each observation have been recorded while the meter is still in the water, the meter can be carried quickly to the next hole and the observations continued. In this way, if no frazil is present, the entire measurement may be completed without having the meter in the air long enough for the water on it to congeal.

When it is necessary to make observations at mid-depth, a coefficient should if possible be determined for reducing the velocity to the mean. If the river is not deep enough to obtain satisfactory vertical velocity curves, a coefficient may be obtained by observing the velocities at 0.2 and 0.8 and mid-depth at a number of sections and comparing the average of the velocities at 0.2 and 0.8 depth with that observed at mid-depth.

When the gage heights fluctuate to any extent while a measurement is in progress, they should be read frequently, and corrections should be made to the recorded observations of depth and computed positions.

\section{NUMBER AND COST.}

The number of current-meter measurements necessary to determine the winter flow of a stream depends so largely on local conditions that no definite rule can be given, but the axiom applicable to open-water measurements-the greater the number the greater the accuracy-applies with equal force to measurements made when ice is present. If the control section of a station is always clear of ice or if the flow is affected only by anchor ice, no more measurements are necessary than are necessary to determine the openwater flow at the same station. If surface ice is present at stations on streams uncontrolled by storage, the number of discharge measurements will depend almost entirely on the temperature; when conditions of temperature and run-off are uniform one measurement a month may be sufficient to insure good records; when thaws are frequent the number increases rapidly, and during certain periods in the winter it may be necessary to make measurements almost daily.

The cost of winter measurements is slightly greater than that of open-water measurements because of the additional time required to make each measurement, the possibility of poor transportation facilities, and the extra help necessary to prepare the section. The extra help can at times be obtained near the station, but for measurements at isolated stations it may be necessary to take an extra man from the office. The average cost of 91 discharge measurements made 
under complete ice cover in the State of Minnesota during the winter of 1911-12 was approximately $\$ 12$, which covered all expenses and is but little greater than the average cost of making open-water meásurements.

\section{PERSONAL EQUIPMENT OF THE ENGINEER.}

The accuracy of discharge measurements made during the winter depends largely on the personal comfort of the engineer making the measurement. The question of clothing should therefore be given considerable attention.

Woolen underwear, much heavier than that worn in the office, is most satisfactory, and if necessary two suits can be worn. A sheepskin-lined coat, either half or three quarter length, is preferable for use in Maine, northern New York, Wisconsin, Minnesota, North and South Dakota, and Montana ; in regions farther south a heavy mackinaw, of a good material, will probably be sufficient. Leather or rubber boots are not as a rule suitable for wear where measurements are to be made through the ice. The standard 8 or 10 inch hunting boots, with rubber feet and leather uppers are waterproof up to 4 or 5 inches, and when worn with German socks, inside which a lighter woolen sock may be worn, will give excellent service under all conditions. The boots should be large enough not to pinch the feet. With this combination the trousers can be tucked inside the socks. An outfit of this type is worn throughout the winter by lumbermen, laborers, and others whose work takes them into snow and water.

When the water stands on top of the ice an extra pair of trousers, which can be slipped on over those regularly worn, will be beneficial, as in cutting holes through the ice more or less water is splashed, which freezes to the clothing.

If the stations are some distance from hotels, two or three pairs of Ieather mittens without fingers and a pair of knitted finger gloves are also desirable. The heavy leather mittens, which should be worn in cutting the holes with the ice chisel, will probably be so wet and frozen by the time holes are cut as to be of little further use until thoroughly dried. In making the discharge measurement a second large pair of mitten gloves can be worn over the' knitted finger gloves; the outside gloves can be pulled off so that the notes can be made without exposing the hand. The woolen gloves will also be serviceable when setting up and repairing the meter. A third pair of gloves will be necessary for use when driving back to the hotel, as it is practically impossible to keep the mittens dry while cutting holes or making discharge measurements.

To one not accustomed to making discharge measurements in the winter, the foregoing details concerning clothing may seem unneces- 
sary, but it is believed that the accuracy of many measurements has been much impaired by hurried work resulting from the personal discomfort of the person making the measurement.

\section{ICE NOTES.}

Many of the notes regarding the thickness of ice at the gage, thickness of ice across the river, and distance from the water surface to the top of the ice required of the gage readers are not used in computing the discharge and therefore are unnecessary. As a rule, the gage reader is not qualified to determine the mean thickness of ice at the control section-information that might enable the engineer to make a fairly accurate estimate of the discharge -and data regarding the distance from the water surface to the top of the ice, which are collected particularly to show whether the ice is in flotation, do not at present enter into the computations. The gage reader should, however, be required to report the first appearance of ice in the river below the gage and the date of its disappearance. The average observer, if carefully instructed, can be so impressed with the importance of his part in the work of collecting streamflow records that he will furnish information other than the routine data called for.

\section{OFFICE METHODS.}

\section{GENERAL FEATURES.}

The winter is most emphatically the time of the year when a dailydischarge record should be kept constantly up to date, so far as possible, for all stations maintained, for one of the important points in connection with records of winter flow is the determination of the time when discharge measurements will be most valuable.

The form of ice and the manner in which the stations are operated tend to separate them in general into three groups: (1) stations at which the control section is open or nearly always open; (2) stations at which the stage is affected by anchor ice and a small amount of surface ice; and (3) stations at which the flow is affected by surface ice only. Each group requires a different manner of treatment.

For stations of the first group the gage heights should be transferred at once from the weekly report cards to the proper form, and the daily discharge should be determined by applying the gage heights to the open-water curve. When discharge as computed seems to be increasing and the temperature records do not indicate a thaw, the station should be visited and a current-meter measurement should be made; if the gage reader has already reported ice that may have gone out by the time the card has been received, the temperature 
record should be used to correct the discharge. When the control section is near the gage, the gage reader can note on the card the presence of the ice, or he may be able to infer backwater from increased gage heights and note it on the card.

For stations at which the flow is affected only by surface ice the same general method can be followed. As a rule, when surface ice has begun to form measurements should be made whenever the daily discharge as computed from the minimum gage height appears, on comparison with the temperature records, to be too large.

For stations at which the flow is affected only by surface ice the best results can probably be obtained by grouping them geographically, according to the results of experience both with the openseason and winter discharge, so that records for a week can be consistently compared. By means of this daily work and constant comparison the engineer can, as a rule, determine when the estimates at a given station are becoming unreliable and when a measurement should be made; knowing the true discharge for the day of measurement, and thus the gage-height correction, he can then correct the back records for that station and for other stations at which the flow is comparable.

By keeping the office work up to date it is, as one of the former engineers ${ }^{1}$ of the Survey has said, "much easier to make discharge measurements at the right time than to make measurements which you trust and pray may be taken at the right time, and then, two or three months later, to wish you had other measurements in place of those you have and still others in place of those that you never took at all."

\section{COMPUTATIONS.}

The computations of winter flow have been more uncertain than any other work in connection with the determination of stream flow chiefly because the field men have failed to collect sufficient data to allow the estimates to be based on fact rather than on fancy. In all computations of open-season flow the various steps leading to the final results are recorded so that they may be checked at any time. No reason is apparent why similar records should not be made of the computations of winter flow. Any estimate has more weight if all the base data are available for inspection. It is therefore suggested that, regardless of the method used to determine the mean monthly discharge and the probable monthly variation in flow, the complete base data be kept in such shape that they can be inspected and the final results checked. Estimates derived from base data which can not be shown should not be published.

Experience has shown that the winter estimates can, as a rule, be made more quickly and more accurately by the engineer who has had 
charge of the collection of the data and is familiar with the local conditions during the observations.

\section{FORMS.}

In order that only such base data as are fundamental will be collected and that these data may be grouped for study in such shape that any method that has yet been proposed can be used, the accompanying form for reporting the daily gage readings has been devised :

Observations of River Height, Temperature, etc., During the Season of Ice.

Station

\begin{tabular}{|c|c|c|c|c|c|c|c|c|}
\hline \multicolumn{3}{|c|}{ Month ............. 191... } & \multicolumn{2}{|c|}{$\begin{array}{l}\text { Water height } \\
\text { on gage. }\end{array}$} & \multicolumn{2}{|c|}{ Temperature. } & \multirow{2}{*}{ Weather. } & \multirow{2}{*}{$\begin{array}{l}\text { Condition of ice below } \\
\text { gage and at riffle. }\end{array}$} \\
\hline $\begin{array}{l}\text { Day of } \\
\text { week. }\end{array}$ & Date. & & A. M. & P. M. & Low. & High. & & \\
\hline & & Time. & & & & & & \\
\hline & & Reading & & & & & & \\
\hline & & Time. & & & & & & \\
\hline & & Reading & & & & & . & \\
\hline & & Time. & & & & & & \\
\hline & & Reading & & & & & & \\
\hline
\end{tabular}

See instructions in gage-height book.

Observer.

The card may call for more data than will be required at many stations, but only under exceptional circumstances will more data be required from the gage reader. The amount of data reported from each station will depend on the character of the stream and of the ice.

The gage-height books should contain the data recorded on the weekly card. The instructions for the observer have been made rather complete in the book but should be supplemented from time to time with circular letters. Temperature and weather should be noted each day. The temperature columns are marked "high" and "low," for it is unlikely that the observers will be able to record the absolute maximum and minimum; if they are careful, however, they will be able to so take the observations that the mean will approach the absolute mean.

To facilitate the study of the base data a form (fig. 18) has been devised on which the data furnished by the gage reader and field men are transcribed. This form, either alone or in connection with a 
graphio plot, such as the plots shown for Kootenai, Schroon, and Elk rivers (Pls. IV and V, and fig. 16) will suffice for computations of winter flow under any conditions and with practically any method. The results of observations can be copied on this sheet as soon as the cards are received from the observers and the computations can be kept up to date by an office engineer.

UNITED STATES GEOLOGICAL SURVEY

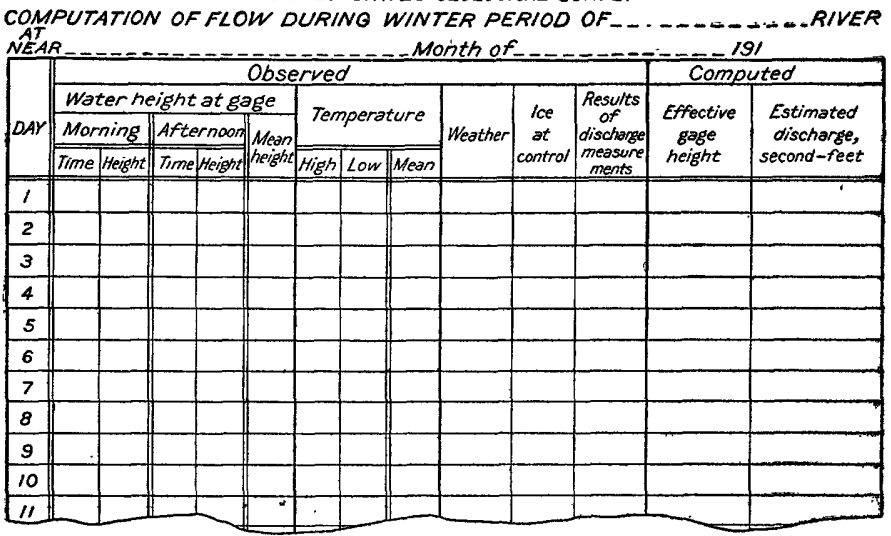

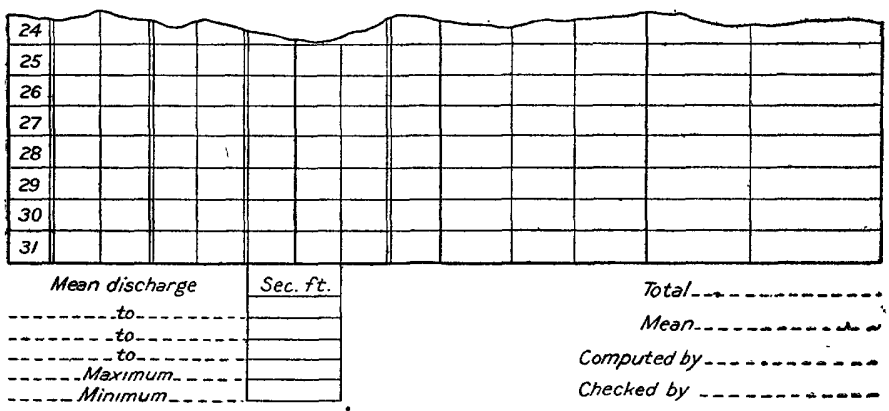

Figure 18.-Proposed computation sheet.

A sheet should be required for each month during which ice is present at a station for which estimates are being made.

\section{ACCURACY.}

\section{DISCHARGE MEASUREMENTS.}

The number and distribution of the discharge measurements made during the winter determine the accuracy of the final computations. In general the individual winter measurement is less accurate than a measurement made in the summer for the following causes:

1. The presence of ice in the river, either covering the surface, attached to the bottom or banks in the form of anchor ice, or floating throughout the cross section as frazil or slush ice. When ice is float- 
ing throughout the cross section the meter soon becomes clogged and gives results that are too low. The meter must be then taken from the water to clean it, and when temperatures are near zero it will quickly freeze.

2. The freezing of the meter while the observer is passing it from measuring point to measuring point or making necessary repairs.

3. Hurry in the work, due to the physical discomfort of the engineer while making the measurement.

4. The inability of the engineer to detect under surface ice eddies or other conditions that disturb the distribution of flow, and his tendency to measure velocities at too few points.

5. The impossibility of measuring the effective cross section as accurately under ice cover as in open water.

GAGE HEIGHTS.

The gage-height records used to determine winter discharge are probably quite as accurate as those employed to determine open-season discharge. The accuracy of the observer's work varies little throughout the year except during periods in which, owing to dangerous condition of the ice, the gage can not be closely approached.

The accuracy of automatic gage records may possibly be impaired by ice which may form either in the intake or in the well.

ESTIMATES OF DAILY AND MONTHLY DISCHARGE.

In general the accuracy of the estimates of daily and monthly discharge will depend on the number of discharge measurements, which in turn will depend on the amount of money available for winter work. The error of daily estimates for days on which no discharge measurements are made is likely to be great. The accuracy of the monthly mean, however, should approach the accuracy with which the mean can be used either in designing or in operating hydraulic plants, which is about 10 per cent, and it is probably not advisable to spend money in trying to obtain winter records much closer than 10 per cent. At stations whose control section remains open throughout the winter or at which the stage is affected by anchor ice only, the accuracy of the record should approach that of the open-channel record. For stations 'on streams uncontrolled by storage and at which flow is affected by surface ice or by frazil, the records can not approach nearer than 10 per cent of absolute accuracy and may fall below 25 per cent. ${ }^{1}$ Records at stations on streams which have a considerable diurnal fluctuation are far less

1 In the scale of accuracy adopted by the United States Geological Survey, $A=$ within 5 per cent, $B=$ within 10 per cent, $C=$ within 15 per cent, and $D=$ within 25 per cent. 
accurate, for the effect of the fluctuations can not generally be determined with an automatic gage, as they can when the streams are open.

The absolute maximum discharge can be determined only by daily measurements. The absolute limits of maximum discharge may be obtained by applying the maximum gage height to the open-water curve, but the necessary correction is always uncertain, so that the maximum discharge as a rule is undeterminable.

If a careful watch is kept of temperature the absolute minimum during the winter should be obtained with almost the same degree of accuracy as during the rest of the year. On uncontrolled streams having little natural storage the minimum flow can generally be determined by measurements made soon after the longest cold period. For streams having a large amount of lake storage the minimum discharge will generally occur almost at the end of the winter, just before the added inflow caused by the spring breakup. 


\section{INDEX.}

A. Page.

Accuracy, degree of..................... 72-74

Acknowledgments to those aiding.

Adams, C. R., on flow in ice-obstructed streams ..................... 49

Affluents, effect of, on ice formation........ 27-28

Altitude, effect of....................... 22

Anchor ice, effects of . ........... 42-48,60-61,62 effects of, gage studies of. ......... 42-48,55-57 formation of ........................ 29-30

Artificial control, effects of................ 23-24 effects of, figures showing............. 23,52

B.

Babb, Mont., gage studies near............ 38-39 gage studies near, figure showing....... 39

Barnes, H. T., experiments of ............ 28-29 ice formula of........................ 25

Barometric pressure, effect of............... 17-18

Bibliography

Big Falls, Minn., winter measurements near, view of.

Bigfork River, Minn., rainfall and run-off on. 20-22 winter measurements on, view of ....... 20

Big Lake, Minn., gage studies near......... 34-35 gage studies near, figure showing....... 35

Bow River, Alberta, gage height and temperature on ........................

Brush, use of, to prevent freezing............

$$
\text { C. }
$$

Cambridge, Minn., winter measurements at, view of.

Cannonball River, Minn., distribution of velocities on, beneath ice, figure showing

Chain gages, use of

Chandler, E. F, on Red River of the North

Channels, forms of, effect of, on ice formation.

Chemung River, N. Y., effect of frazil on fiow of, figure showing.

Chinook winds, effect of.

effect of, figure showing.

Climatic factors, descriptio ${ }^{2}$

See also Precipitation; Temperature; Wind; Barometric pressure.

Climatologic records, character of

Clothing, character needed for winter measurements

Computations, making of

Connecticut River, ice period on........... $\quad 27$

Control, artificial. See Artificial control.

Control sections, classification of........... 69

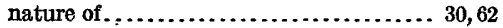

relation of, to surface ice........ 31,33-34,49,62 figure showing.................... 33

selection of ......................... 59

Covert, C. C., work of. ................... 8
Crow Wing River, Minn, gage studies on ... gage studies on, figure showing......... 37 Curves, rating. See Rating tables.

D.

Dams, ice on, errors due to................

Discharge, daily and monthly, estimates of, accuracy in................... 73-74

Discharge, temperature, and gage heights, relations of.................... 7

relations of, plate showing............. 46,48

Discharge under ice, computation of...... 30,48-57

measurements of, accuracy of.......... 72-73

instruments for...................63-64

methods of .................... 64-67

number and cost of ..............6.67-68

section for, determination of......... 62

timing of ........................ 70

E.

East Grand Forks, Minn. See Grand Forks, N. Dak.

Elk River, Minn., gage studies on......... 34-35

gage studies on, figure showing........ 35

Engineers, equipment of . . . . . . . . . . . . . 68-69

Evaporation, effects of .................. $\quad 70$

Eye method of computing discharge........ 51-52

F.

Field methods, description of............. $57-69$

Forms, figure showing................... 72

use of . . . . . . .

Frazil, detection of.................... $\quad 65$

effects of . . . . . . .

figure showing..................... 41

formation of......................... 28-29

Frozen ground. See Ground, frozen.

G.

Gage heights, on ice-obstructed streams, computation from ............... 48-57

on ice-obstructed streams, determination

of . .......................... 34

deiermination of, accuracy of....... 73

Gage heights, temperature, and discharge, relation of, plate showing..... 46,48,52

Gaging stations, selection of. ............ 57-59 studies at, details of . ........... 34-40,42-48

value of ......................... 32-34

Gages, types of, description of...........60-61

Genesee River, ice period on............... $\quad 27$

Geologic factors, effect of . ............... 19-20

Gradients, effects of . ..................... 22-23

Grand Forks, N. Dak., gage studies near.... 37-38 open-water and under-ice fiow near, relation of, plate showing.......... $\quad 38$ 
Graphic computation of discharge, description of . . . . . . . . . . . . . . .

use of ............................ 55-57

figure showing $. \ldots \ldots \ldots \ldots \ldots \ldots \ldots, 46,54$

Ground, frozen, effect of ................ 9,10,11

normal depth of.

Ground water, amount of, effect of topography on .......................... 20-22

amount of, relation of, to winter How .... 20

fluctuation of, with seasons............ 9-10

figure showing.................... 10

release of $. . . \ldots \ldots \ldots \ldots \ldots \ldots \ldots \ldots . .12$

H.

Havre, Mont., temperature rise at, figure showing.......................

Hudson Bay, drainage in Minnesota, relation of flow and temperature on......

\section{I.}

Ice, effect of

formation of.

11

inaccuracy due to

24-30

measurements under. See Discharge, measurements of

See also Surface ice; Frazil; Anchor ice.

Ice chisel, plate showing................. use of.

Ice holes, cutting and spacing of

nlinois River, ice period on

Instruments for measurements under ice, nature of ............ 63-64

International Falls, Minn. See Rainy River.

$$
\text { J. }
$$

Jones, B. E., work of.....

\section{K.}

Kanawha River, ice period on............ $\quad 27$

Kootenai River, Mont., gage studies at. 13,42-48, 53 gage studies at, figure showing. . .......43,46

I.

Lakes, effects of fiow from, effect of, on ice............. $\quad 27$

Lake Superior drainage in Minnesota, relation of flow and temperature on .

Lamb, W. A., work of.

Latitude, effect of.

Libby, Mont., gage studies at. . ...... 13, 42-48, 53 gage studies at, figures showing. .........43,46

Littlefork River, rainfall and run-off on...... 20-22

\section{M.}

Measuring stick, plate showing. use of.

Merrimas River, $\mathrm{N}, \mathrm{H}, \mathrm{i}$, peri

Minimum flow, season of .

Minnesota, minimum flow in............. 16-17

minimum temperature in............... 16

relation of topography and storage in.... 20-22 figure showing................... 21

Minnesota River, Minn., ice period on ....... 27
Page.

Minnesota streams, relation of flow and temperatures on.................... 13-17

Mississippi River, ice period on............ 27 relations of flow and temperature on..... 12-13

figure showing.................... 12

Mississippi River drainage in Minnesota, relation of flow and temperature on.

Missouri River, ice period on ...............

Mountain streams, effect of freezing on....... 11

\section{N.}

Needle ice. See Frazil.

\section{O.}

Office methods, computations, use in...... 70-71 forms used in...................... 71-72

figure showing................... 71

nature of . . . . . . . . .

Ohio River, ice period on................ 27

Open-season flow, lack of uniformity in..... 57-58

\section{P.}

Percolation, prevention of, by freezing...... 10,11

Peters, F. H., work of................... 8

Piercefield, N. Y., gage studies at............ 39-40 gage studies at, figure showing......... 40

Pillager, Minn., gage studies at............ 36-37 gage studies at, figure showing.......... .37

Power-plant records, value of............. 50-60 Precipitation, effect of............... 9-10,16-17

Publications, lists of.

8

R.

Rainy River, Minn., artificial control of...... 24 artificial control of, figure showing..... 23, 52 discharge curves for.................. 51

figure showing.................... 50 discharge of, computation of ........... $52-53$

figure showing................... 46 gage studies on, plate showing.......... 52

Raquette River, N. Y., gage studies on..... 30-40 gage studies on, figure showing.......... 40

Rating curves. See Rating tables.

Rating tables, open-water, applicability of.. 7 changes in, by ice.................. 30,31

figure showing..................... 33 computation by, on ice-obstructed streams....................... 48-49 relation of, to ice rating tables, plate showing..........................

Rating tables, special, on ice-obstructed streams, figure showing..........

on ice-obstructed streams, use of........ 49-51

Recording gages, use of ................. 60-61

Records, winter, factors in................ 8 interpretation of................... 8 importance of ....................... 7

Red River of the North, fioods on.......... 22 gage studies on . ..................... 37-38 ice period on ......................... 27 open-water and under-ice fiow on, relation of, plate showing............ 38

Reservoirs, effect of...................... 23-24 records of........................ 59-60

Riverbank, N. Y., gage studies at........... 48 gage studies at, plate showing.......... 48

Rum River, Minn., ice storage on......... 10 winter measuraments on, view of....... 10 
Page.

st. Croix River, Wis., ice period on.......... 27

St. Mary River, Mont., gage studies on..... 38-39 gage studies on, figure showing......... 39

Sauder, P. M., work of................... 8

Schroon River, N. Y., gage studies at........ 48 gage studies at, plate showing......... 48

Shoal Pond Brook, N. H., winter measurements on, view of ............. 64

Slichter, C. S., on barometric pressure...... 17-18

Slush ice. See Frazil.

Snow, effect of ......................... 9,11

Springs, effect of, on ice.................. 28

Staff gages, use of ...................... 60

Stage and discharge, relations of .......... 7, 30, 31

Stream flow, effects of ice on, computation

of ....................... $48-57$

fluctuations of, effect of, on ice formation. records of, importance of

velocity of, effect of, on ice formation.... See also Winter-flow records; Discharge.

Surface ice, affluents and, relations of. 27-28

bridging by, effect of ................ 31 discharge under, graphic computation of. 52-53

flgures showing.................... 54

duration of ......................... 25-27

effects of . ........................... $31-40,60$

gaging-station studies on .......... 32-40

fluctuations and, relations of .......... 28

friction of .......................... 31

formation of ........................ 24-25

stream bed and, relations of.
Surface ice, velocity of water and, relations of. Susquehanna River, Pa., ice period on.......

T.

Temperature, effect of ................. 10-17

effect of, plates showing............46,48,52

figure showing..................... 12

Topographic factors, effect of ............ 20-23

V.

Valley streams, effect of freezing on......... 11

Vegetational factors, effect of.............. 23

Velocities under ice, distribution of......... 31-32

distribution of, figure showing.......... $\quad 32$

laws of ............................ 8

Vermilion River, Minn., rainfall and run-off on .......................... 20-22

winter measurements on, view of ........ 20

W.

Winds, warm, effects of ................ 18-19

effects of figure showing............... 18

Winter-fiow factors, classification of......... 9

description of.......................... 9-24

See also Climatic factors; Geologic factors;

Topographic factors; Vegetational factors; Artificial factors.

Winter-flow records, importance of......... $\quad 57$

stations for ....................... 57-59

Y.

Yellowstone River, ice period on 


